Historic, Archive Document

Do not assume content reflects current scientific knowledge, policies, or practices. 



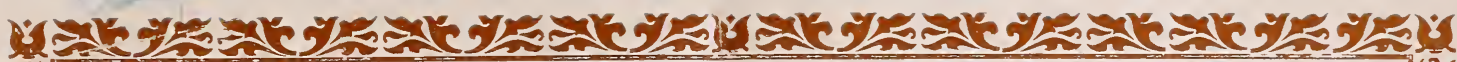

太ู

获

William ParRy SPRING.1899

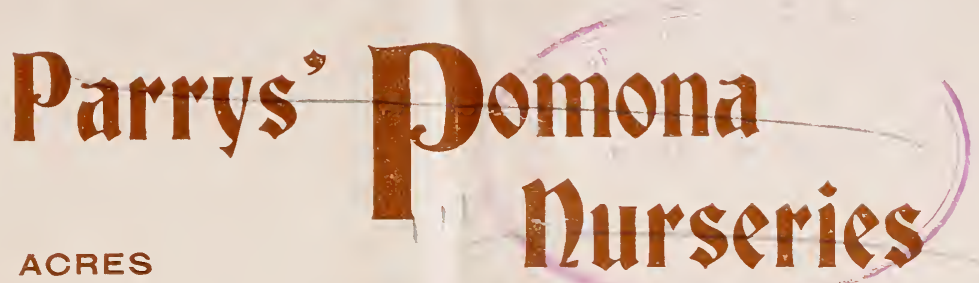

300 ACRES

है

in

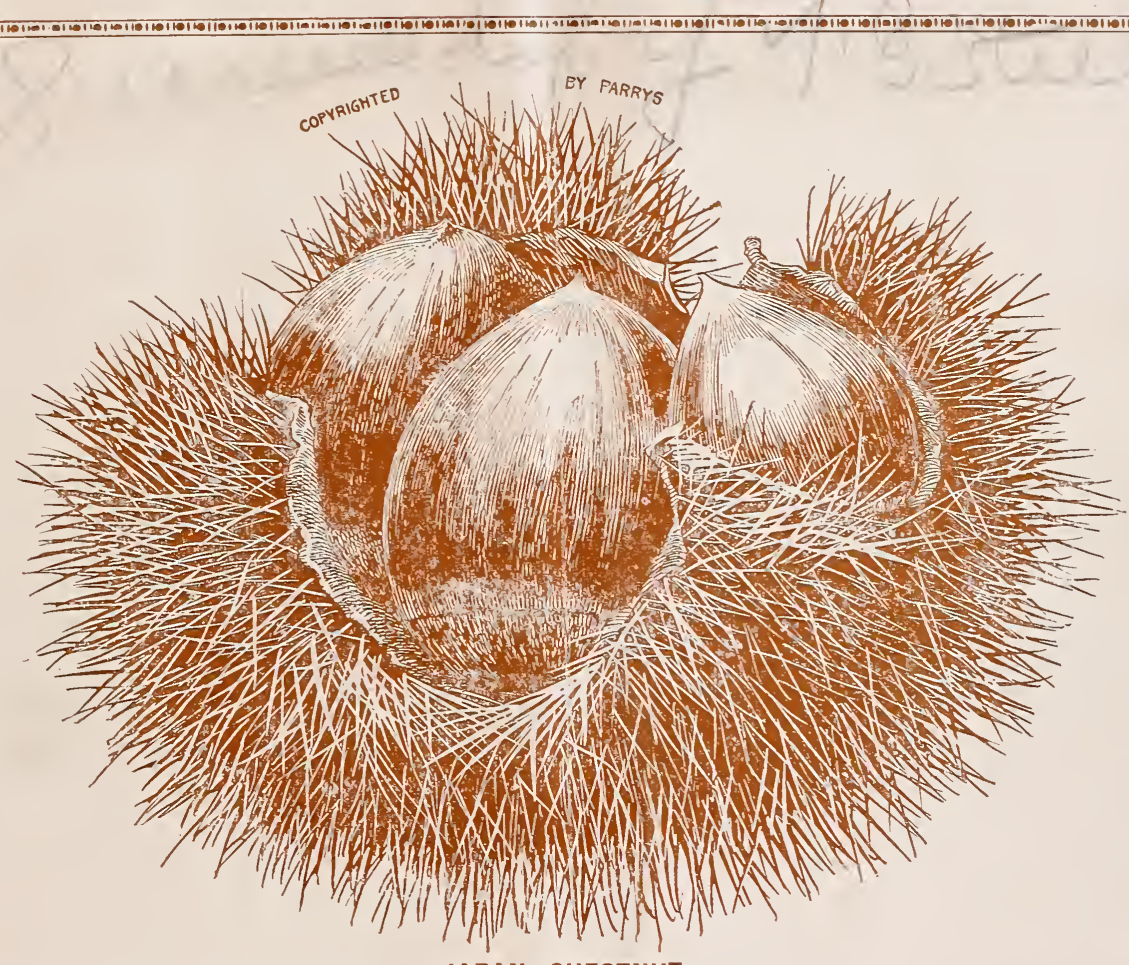

JAPAN CHESTNUT.

OUR SPECIALTIES ARE BEST NUT-BEARING TREES:

Japan, American and European Chestnuts; Japanese Walnuts, Sieboldiana and Cordiformis; Persian Walnuts, Kaghazi, Madeira, Etc.

FRUIT, SHADE AND ORNAMENTAL TREES, SMALL FRUIT PLANTS, ETC.

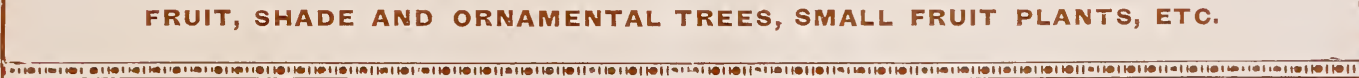

\section{PARRYS' POMONA NURSERIES} PARRY 


\section{Conditions of Sale.}

We offer no ehromos or prize packages as an inducement to buy our trees and plants, but give our patrons more than their value in quality of stock, careful packing, good count, ete.

The prises in this Catalogue abrogate previous quotations. The prices affixed are for quantities specified, but half-dozen, 50 and 500 trees or plants will be supplied at dozen, 100 and 1,000 rates respectively.

If your order amounts to $\$ 10$ or more, accompanied by the cash, we will furnish an assortment of stock, 100 of any one kind at 1,000 rates, one dozen or more of any one kind at 100 rates.

Large packages will be delivered at Riverton Station free of cost, after which they are at the risk and expense of the purchaser. In case of loss or delar, the purchaser must look for clamages to the forwarding companies alone. Packages by mail are postpaid by us.

Substitution. When varieties are ordered which we do not have in stock, others, similar or better, will be substituted, unless we are requested not to substitute by the person ordering.

No elaims will be allowed unless made within ten days after receipt of goods.

We exereise care that all our stock shall be genuine, unmixed, trme to name and quality represented, free from insects and disease, and accept your order with the understanding and agreement that should any prove untrue to name, we will replace them with genuine stock; or shoull stock be infested or diseased when received, we will replace with clean and healthy stock; but we are not liable for damages other than 'herein named.

For eash with order, deduet 10 per eent from the list price 3 THe make no: chard for packing, except on shade and ornamental trees.

No discount unless eash reaches us before shipment. No discount on special cillections.

Money can be sent safely by Post Office Orter on Parry $\mathrm{P} O$, Burlington County, $\mathrm{N}_{-} \mathrm{J}$., Bank Check, Draft; or"Registered Letter, directed to-

\section{PARRYS'-POMONA NURSERIES; Parry PO O,; Bürlington Co,, N. J \\ TPECIA工 NOTICE! SE :}

To insure our enstomers against the many injurious insects to which nursery stock is subject, to wit : oyster-shell louse, Harris scale, San José scale, midge, psylla, and other's, we have built a fumigating house, wherein all stock shipped by us except Evergreens, Strawberry Plants and Hardy Herlaceous Plants, is thoroughly fumigated, under the specific instructions of the state entomologist.

\section{DISTANCES FOR PLANTING, \\ Number Required to the Acre, and Time Required to Come to Fruiting.}

FRUIT TREES.

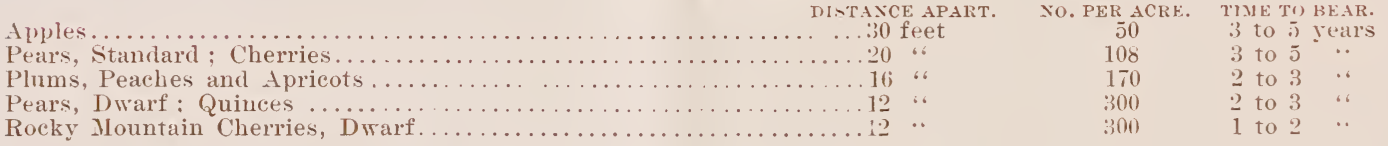

NUT TREES FOR FRUITING.

Pears, Dwarf : Quinces ...........
Rocky Mountain Cherries, Dwarf

DISTAXCE APART.

Chestnuts-American and spanish

40 feet

$$
\text { Japan }
$$

Walnuts-Persian

Pecans, Shellbarks and Butternut.

Almonds-Hard and Soft Shell....

Filberts and ('hinquapins...

40

30

(3)

16

\begin{tabular}{|c|c|c|c|}
\hline XO. PEK ACRE. & TIME & To & BEAR. \\
\hline . 8 fritated. & 2 to & 3 & years \\
\hline -o I Seedlings. & 8 to & 10 & . \\
\hline - $\int$ Cirafted. & 1 to & $\underline{2}$ & $* 6$ \\
\hline 0 Seedlingx. & 3 to & 4 & $\cdots$ \\
\hline & (i to & 8 & $\cdots$ \\
\hline 50 & \pm to & j) & . \\
\hline 2 & 6 to & 10) & $\because$ \\
\hline -0 & 1 to & 2 & “ \\
\hline 4.3 .5 & $\because$ to & 3 & $\cdots$ \\
\hline
\end{tabular}

SMALL-FRUIT PLANTS.

WISTANCF, OF ROWS APART. MSTANCE OE PIANTSAPART.

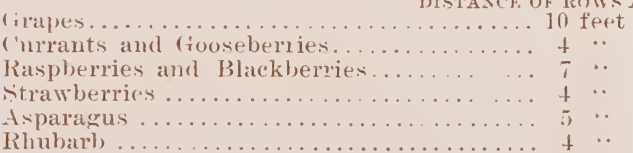

$\begin{array}{ll}8 & \text { feet } \\ 4 & \cdots \\ 3 & \cdots \\ 1 & \\ 1 & \cdots \\ 2 & \cdots\end{array}$

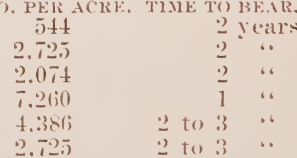

\section{WEIGHT OF TREES AND PLANTS PACKED.}

Fruit Trew.

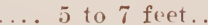

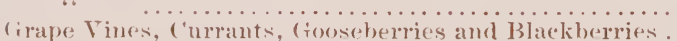

Rasplueries

itrawbervics
AVERAGE WEITHT

100 pounds to 100 trees.

3 to 5 feret.

2.) to 50

10 to to 100 trees.

to 5 pouncls per 100 plants.

2) to 2.5

100

1.000

dureing weight and express charges proportionately.

TREES AND PLANTS BY MAIL A SPECIALTY. 


\section{PARRYS' POMONA NURSERIES}

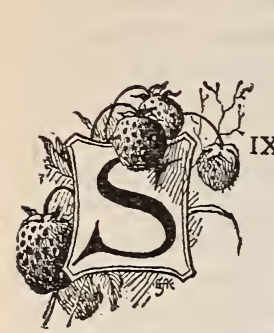

WM. PARRY, PARRY, N. J.

brought forward, comparatively few retain prominence long.

Our experimental grounds, on which the different varieties are grown under similar treatment, although expensive, are interesting and useful to those about to form new plantations, and all such are invited to visit our nursery and inspect the different fruits and nuts in bearing.

The character for accuracy, promptness and fair dealing which this establishment has earned and enjoyed for 61 years renders it unnecessary for us to publish a list of references or testimonials from the volumes of letters in evidence of our perfect packing, the good condition in which plants are received, satisfactory count, etc.

Fruit growers can not fail to realize that SUCCESS depends upon getting GENUINE, PURE, WELL-GROWN PLANTS, CAREFULLY and. SECURELY packed. As we have devoted more than THREE SCORE YEARS to the business, have at the heads of our sereral departments men who have been with us a quarter of a century or more, and are conversant and familiar with every peculiarity and characteristic of the different varieties of trees and plants, which, under our system of cultivation, guarded care, ete., render it next to impossible for our stock to become mixed or impure, or to suffer in transportation; and as "practice makes perfect," we are enabled to furnish TREES AND PLANTS PURE AND UNMIXED, at THE LOWEST POSSIBLE PRICES. Results obtained through buying stock thus grown by such a firm must be immeasurably superior to those secured from buying of irresponsible agents, dealers and others who are but little acquainted with the business, having no fruit of their own growing to sell or exhibit.

In presenting this, our 122nd semi-annual Catalogue, we are pleased to announce that our stock of trees and plants is of UNUSUALLY GOOD QUALITY, XIORE EXTENSIVE than in former years, and that the utmost care and best attention will be given all orders.

Our packing season for spring begins January 1 and continues until June 1, and our first shipments are to the most extreme points south and to the Pacific coast. In the fall we begin shipping in September, and continue through October, November, and until the ground is frozen in December.

Parrys' Pomona Nurseries are located on the branch of the Westfield and Camden Turnpike, two miles from Riverton, three from Noorestown, and eight from Burlington and Philadelphia. A steamboat leaves the latter place for Riverton several times daily, and the cars running between Philadelphia and New York stop at Riverton.

These Nurseries are now the exclusive property of MIrs. William Parry, who has purchased the interest of John R. Parry therein. The business will be conducted in the name of $W \mathrm{~m}$. Parry, and under the management of practical and experienced men, as hitherto, so that customers may rely on the same LIBERAL TREATMENT, PROMPTNESS and FAIR DEALING shown in the past. We earnestly solicit a liberal share of your patronage, and all orders shall have the very best attention.

Being in direct communication with Philadelphia and New York, our shipping facilities are unsurpassed, while our experience and system of packing enable us to send trees and plants by mail or express in safety to any part of the country, however distant.

Packages for us should be directed to RIVERTON, N. J., either by express or by freight.

Money Orders should be drawn to PARRY P. O., Burlington county, N. J., and sent to PARRYS' POMONA NURSERIES, Parry P. O., New Jersey.

Express, Telegraph and Freight Depot, RIVERTON, New Jersey.

(Pennsylvania Railroad, Amboy Division.)

Money Order Office and Post Office,

PARRY, New Jersey.
Address all orders to

\section{PARRYS' POMONA NURSERIES,}

\author{
PARRY, NEW JERSEY,
}




\section{PLANTING HINTS FROM A RIPE EXPERIENCE.}

Our threescore years' experience in growing and testing fruits, propagating, digging, packing and shipping nursery stock, may be of some service to intending purchasers. It is our desire that all orders entrusted to our care shall be executed in the best possible manner, that they reach our customers in good condition, and succeed for them. We are mutually benefited by such transactions. We therefore give some instructions which may prove of interest and benefit. If your stock is shipped by express, it should arrive within a day or two of your shipping advice; if by freight, one to two or three weeks later, according to the distance.

Care of Trees and Plants on Arrival.-If not ready to plant the stock the day it arrives, or if you have more than you can plant within a few hours, it should be at once heeled-in. Select a well-drained spot, dig a trench about 18 inches deep, sloping on one side; place the roots in the bottom of trench with the tops leaning up the sloping side. Spread out the trees so that the earth will come in contact with every root; then sift in fine dirt among the roots, fill the trench partly full, and press firmly with the feet. Fill up level with the top of the ground and press again with the feet, covering with loose dirt. Trees thus "heeled-in" will keep in good condition a long time. Do not cover with litter or straw, as it will harbor mice during winter.

If stock is frozen when received, bury the package, UNOPENED, in well-drained ground, or place in a cool cellar, so that it will thaw out slowly and gradually without being exposed to the air.

If stock should appear dry or shriveled when received, through delay in transit or any other cause, take from the package and plunge into a tub of water; or bury the roots in the ground in an inclining position so as to cover one-half or more of the tops with the earth, thoroughly soak with water and let it remain for 24 hours or more until it regains a fresh, plump appearance, when it may be planted.

Planting.-Dig the holes wide enough to admit the roots in their natural position, without cramping, and deep enough to allow the trees to stand the same depth they stood in the nursery, except dwarf pears, which should be set a little deeper, so as to cover the quince stock on which they are worked. Throw the surface and subsoil into separate piles. Cut off smoothly from the under side all broken or bruised roots, and cut back the last season's growth of top one-half to two-thirds, leaving two to three good buds to each branch-except for fall planting in cold climates, when it is best to defer top-pruning until spring, just before the buds start. At all times keep the roots carefully protected from the sun and wind. Place the tree in the hole; fill in with fine surface soil, working it in among the roots, which must lie in their natural position. When the hole is half full, pour in a little water and press firmly with the foot, filling all cavities and air spaces with earth so that it will come in contact with all the roots. Continue to fill up and keep pressed until the hole is full, when it should be covered with loose dirt to prevent baking. BE CAREFUL NOT TO GET THE TREES TOO DEEP.

Never put any manure in the holes. A little bone dust or good rich soil is best in the bottom of the hole. Fertilizers should be applied to the surface and worked in. A covering of coarse manure, straw, litter, hay, or even stones the first season, will retain the moisture, prevent injury from drought, and be of great benefit during a dry season.

Small fruit plants should be set in a pail containing two or three inches of water and taken out one at a time as planted, not allowing the roots to be exposed to the sun or air. If not ready to plant strawberries on arrival, do not pour water on them in the package or in the bunches, as they will surely heat and spoil. They may be spread out thinly in shallow trenches, with their crowns even with the surface, heeled-in, as advised for trees, sprinkled with water and shaded for a few days.

\section{SPECIAL NOTICE TO CUSTOMERS.}

The prices of nursery stock, especially some varieties, have advanced since last season from 60 to $100 \%$, owing to the increased demand due to more prosperous times and to a depleted supply of stock generally.

We have endeavored to price our list as low as possible, but in cases where our customers desire special quotations for large quantities, we will take pleasure in furnishing such.

PARRYS' POMONA NURSERIES, Parry, New Jersey. 


\section{Apples. \\ PRICES OF APPLE TREES.}

\begin{tabular}{|c|c|c|c|c|}
\hline \multicolumn{2}{|l|}{ 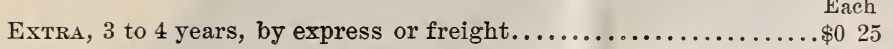 } & $\begin{array}{c}\text { Per doz. } \\
\$ 250\end{array}$ & $\begin{array}{c}100 \\
\$ 2000\end{array}$ & $\begin{array}{c}1,000 \\
\$ 15000\end{array}$ \\
\hline 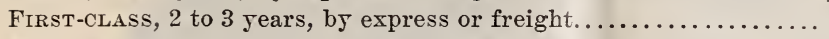 & 20 & 175 & 1250 & 11500 \\
\hline Menius, 2 to 3 jears, by express or freight... & 15 & 125 & 1000 & 9000 \\
\hline MaILING, 1-Jear, mail or express......... & 10 & 100 & 600 & 5000 \\
\hline BISMARCK, 1-year, extra, 3 to 5 feet, by expr & 40 & 400 & 3000 & \\
\hline 1-jear, fine, 2 to 3 feet, by express & 30 & 300 & 2500 & \\
\hline 1-year, 1 to 2 feet, mail or express. & 20 & 200 & 1500 & \\
\hline FloRy (Winter Banana), 1-year, mail or expr & 15 & 150 & 1000 & \\
\hline 2-year, express.... & 20 & 200 & 1500 & \\
\hline STARR, 2-year, fine, 4 to 6 feet, well-branched, by & 50 & 500 & 4000 & \\
\hline 1-year, medium, 2 to 3 feet, whips, mail or express....... & 25 & 250 & 2000 & \\
\hline 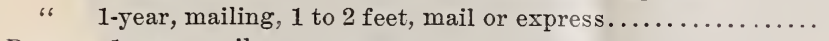 & 20 & 200 & & \\
\hline PARLIN, 1-Jear, mail or express. & 20 & & 1500 & \\
\hline 2-year, stocky, well-branched, by expr & 30 & & & \\
\hline
\end{tabular}

Special quotations for large quantities.

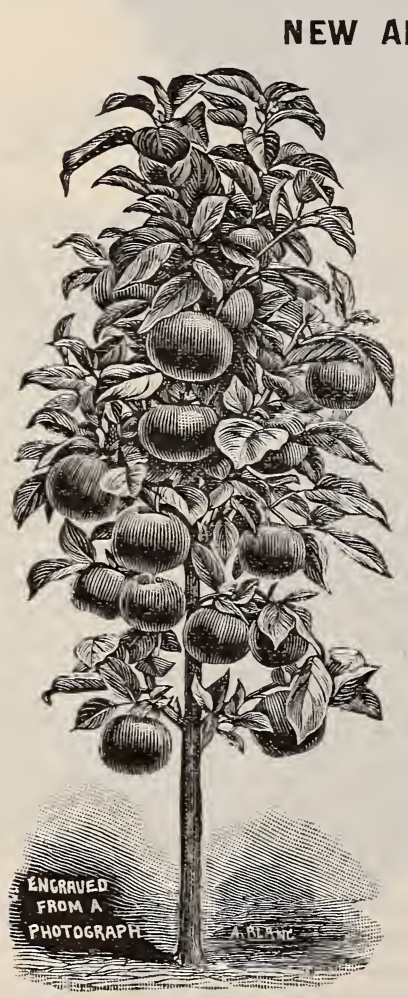

Bismarck Apple Tree.

BISMARCK. BEARS FRUIT ON 2-YEAR GRAFTS. OF FINEST QUALITY, FINEST COLOR, DWARF AND EXTREMELY PROLIFIC; most suitable Apple for hot climate, yet THE HARDIEST KNOWN. A prominent firm boldly asserts that 1-year grafts bore as many as eight fruits, that 2-year-old trees seldom fail to produce good crops, and that the tree is an excessive bearer and extremely hardy. The tree is of short, stocky growth, and. when laden with handsome fruit at one or two years old, is a pretty pot plant for table or greenhouse decoràtion. The tree is a hardy, vigorous grower, and the Apples are very sound, solid and heavy. It is especially recommended for gardens when grafted on Paradise stock. Fruit is large, brilliantly col- ored and very handsome; flesh tender, pleasant subacid, of distinct aud most delicious flavor, unequaled as a dessert Apple, very superior for cooking, and will keep in an ordinary room till March. Being among the first to offer this rare and valuable variety, we now have a vel'y fine stock of trees, and have made prices low so as to induce liberal planting.

Paragon. A seedling from Tennessee. The original tree, over 50 years old, is still vigorous and bearing, though mutilated by storms. The young trees show great vigor of growth, come to bearing very young, and are very productive. Fruit large, roundish, somewhat flattened; color dark red, slightly streaked; flesh firm, yellow, crisp, aromatic, subacid and juicy. It is A VERY LATE KEEPER, rich and of excellent quality. Thought to be a cross between Winesap and Limbertwig, combining the good qualities of each. Its full size, showy appearance, long keeping and splendid shipping qualities, together with its excellent flavor, render it very valuable as a market or family variety.

STARR. The original tree of this most valuable Apple was found on the grounds of Judge John Moore White, of Woodbury, N. J., which property afterwards came into possession of Mrs. Starr, whose son John Starr, while in the Legislature with the late William Parry, about 1865, gave him cions from which he grew and fruited it under the name of Starr Apple. It has proved A VERY VALUABLE AND DESIRABLE EARLY MARKET APPLE, having created for itself such a reputation that it is always sought after and bought up by faney grocers at high prices, even when other good varieties are selling low. The tree is a good grower, comes to fruiting young, and produces abundant crops annually. Fruit is very large, 11 to 12 inches around; showy, pale green, frequently with handsome blush on sunny side; very early, marketable first week in July, and will continue in good condition until September. An excellent shipper for so early an Apple, having carried to California in good condition. Flavor pleasant, subacid; a very superior Apple for cooking or eating. 


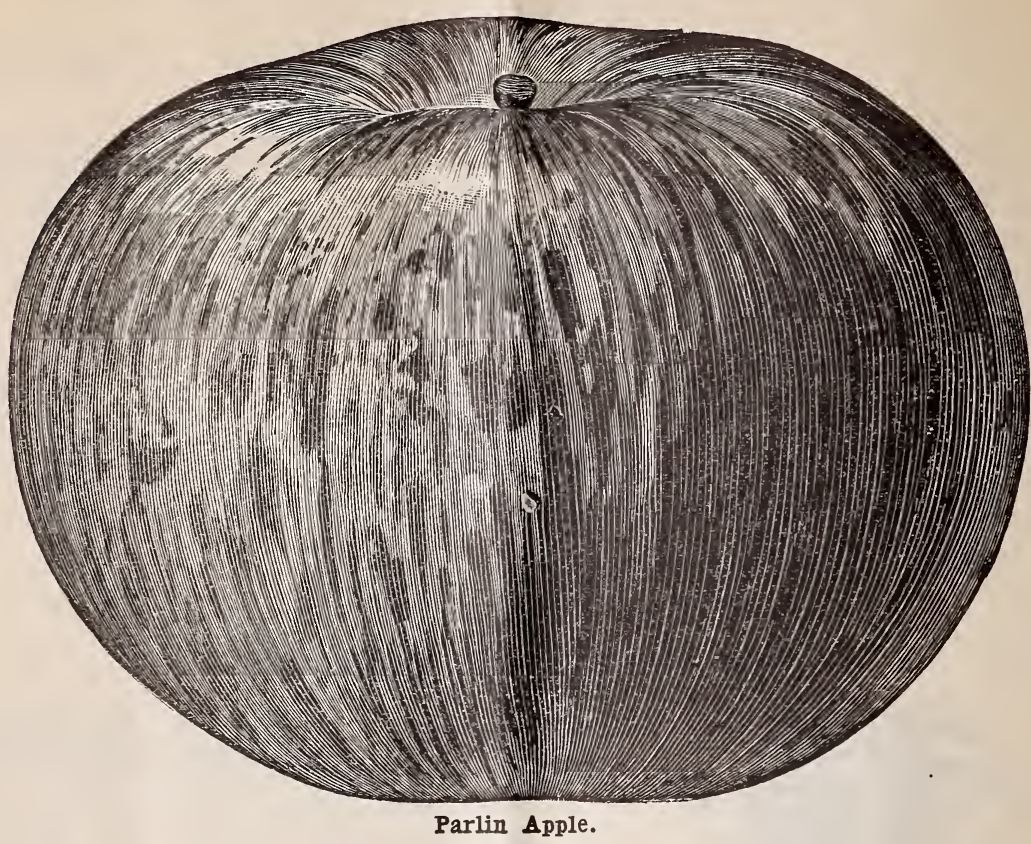

PARLIN. From Maine. The original tree is still standing, vigorous and healthy, though over 50 years of age. VERY HARDY, having withstood, uninjured, very low temperature. A good grower and very productive. FRUIT VERY HANDSOME, splashed and striped with red; of good quality; marketable early in September, immediately after Maiden's Blush, and continues growing better and handsomer for two or three months.

\section{APPLES, continued.}

Yellow Transparent. Earliest ripening Apple known. Of Russian origin; medium size, light transparent lemon-yellow; flesh juicy, pleasant, subacid. July.

Early Sweet Bough. Very large, greenish yellow, sweet, good. Early.

Early Harvest. Medium size; yellow; very good. Early.

Orange Pippin. Medium size; golden yellow; very productive and valuable. Early.

Maiden's Blush. Good size; yellow, with red cheek; good for cooking or dessert. Early.

Grimes' Golden Pippin. Golden yellow; of good size, round and firm; excellent. December to March.

Smith Cider. Medium size; greenish white, striped with red; very productive. December to March.

Fallawater. Very large; color green, with red cheek; good keeper. November to March.

FLORY, or WINTER BANANA. An accidental seedling of Indiana, claimed to be THE FINEST, MOST PROFITABLE, MOST PRODUCTIVE HARDY APPLE YET DISCOVERED. One of these Apples placed on a table will soon fill the whole room with a delightful banana perfume. This wonderful and very large Apple is nearly as hardy as the native Crab, having passed through severe winters unhurt, when many other varieties were entirely killed. It is unsurpassed for beauty; golden yellow, with slight blush or tint of red on sunny side. It is of excellent subacid flavor, much resembling a banana; a delicious Apple for eating and cooking. It is a good keeper, remaining in good condition until April. Tree is a vigorous, upright grower; the top buds generally produce fruit at two years of age, bear annually, and increase in number with age. It would be difficult to imagine a winter Apple possessing more desirable features for family or market than the Flory, or Winter Banana.

Baldwin. Large, dark red of good quality; productive. December to March.

Langford. Large, deep red, good quality; productive, late.

Ben Davis. Good size, red; very productive and showy; late.

Ridge Pippin. Yellow, large, firm, good quality; long keeper.

Winesap. Medium size, dark red, rich flavored; very productive; late.

Delaware Winter. Large, dark red, good quality; productive; very late.

\section{ADDITIONAL VARIETIES.}

The following are among the many other varieties we have in stock and can furnish: RED AsTRAChan, Early Hagloe, Williams' Favorite, GraveNSTEIN, SMOKEHOUSE, COOPER'S REDLING, Roman Stem, Roxbury Russet, Wm. E. Red, King, Salone, GaNo, R. I. Greening, HubBARDSTON.

\section{CRAB APPLES.}

Siberian, Marengo, Whitney, No. 20, Hyslop. Desirable for preserving, and are planted largely as ornamental lawn trees. 


\section{Pears.}

STANDARDS should be planted 20 feet apart each way, taking 108 trees to the acre, and dwarfs set each way between them. The ground should be thoroughly cultivated until the trees come to bearing; vegetables, potatoes, or vine crops can be grown to advantage for a few years.

\section{PRICES OF PEAR TREES. \\ New Varieties.}

Each Per doz. 100

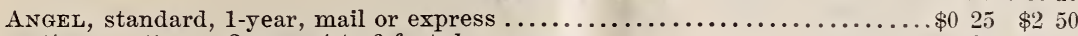

" " 2 -year, 4 to 6 feet, by express ....................... 35 . 350

Lincoln CoReless, standard, 1-year, mail or express .................. $20 \quad 200$

JAPAN Golden RUSSET “" $\quad$ 1-year, 2 to 3 feet, mail or express $\ldots \ldots \ldots \ldots \ldots$. $25 \quad 250$

1 -year, 2 to 3 feet, mail or express............ 15 1 150

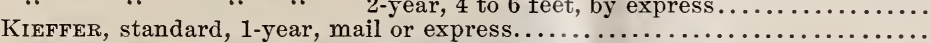

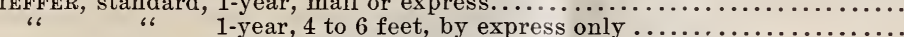

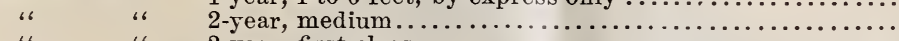

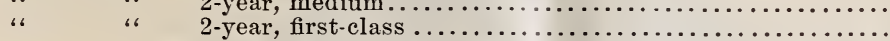

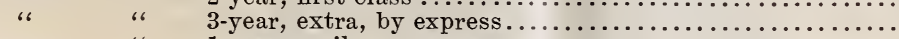

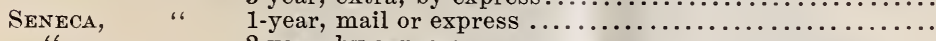

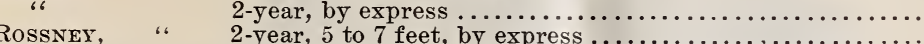

250

$150 \$ 1000$

$200 \quad 1250$

$250 \quad 1500$

$\begin{array}{llll}2 & 50 & 15 & 00 \\ 3 & 00 & 20 & 00\end{array}$

$\begin{array}{lllll}4 & 00 & 30 & 00\end{array}$

Special quotations for large quantities.

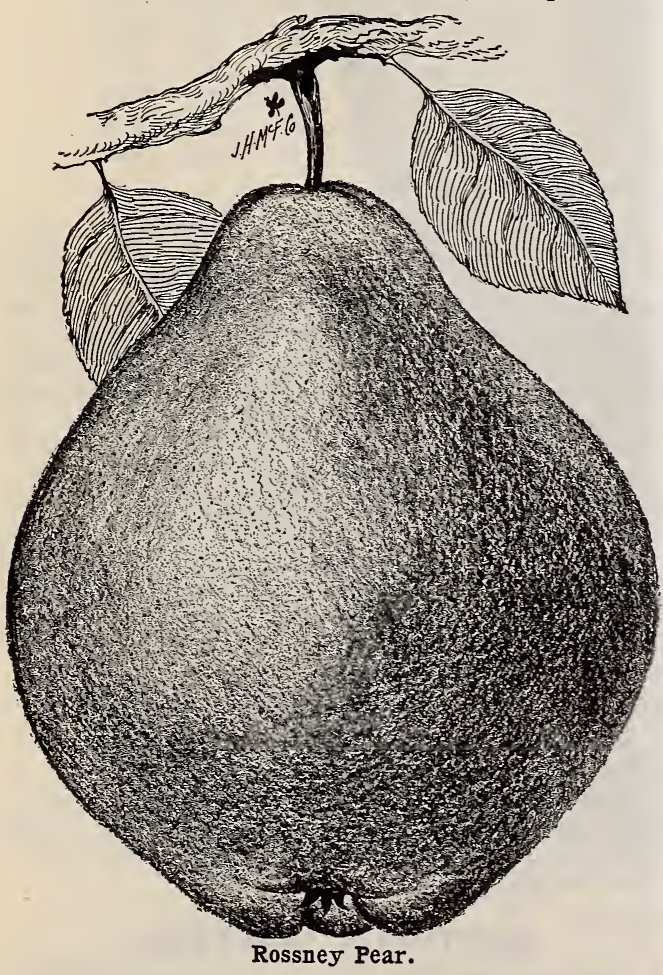

ROSSNEY. A new and excellent Pear, raised from seed at Salt Lake City, Utah. In size medium to large; flesh very finegrained, melting, juicy, very sweet. Ripens two weeks after Bartlett; is an excellent keeper and shipper. The tree is much stronger than Keiffer.

LUTHER BURBANK SAYS, under date of October 5, 1895: "The samples of Rossney Pear arrived in due season. The large size, handsome form, and creamy yellow skin with crimson blush, give the fruit a tempting appearance; and the tender, creamy flesh, of just the right texture and of superior flavor, with no hard spots and an unusually small core, make it ABOUT THE BEST PEAR SO FAR SEEN. If the tree is vigorous, healthy and productive, would prefer it to any other, even the standards, Bartlett or Seckel.
KOONCE. A chance seedling found on an old farm in Illinois. The original tree was very old when discovered, and gave evidence of having produced heavy erops of fruit. The introducer began propagating it, and soon had a large orchard in bearing. It has now been thoroughly tested in orchards and proved THE VERY BEST EARLY PEAR. Tree is very vigorous, free from blight, upright, and claimed to be a better grower than Kieffer. Fruit medium to large; skin yellow, covered on one side with bright red, rendering it strikingl handsome; of a fair quality seldom found in an early Pear; ripens two weeks earlier than Harvest Belle or Jefferson; does not rot at the core: MOST VALUABLE EARLY market Pear before the public, and will be largely planted.

ANGEL. The original tree, though very old, is still standing in a fair state of preservation in Columbia county, New York, and producing abundant crops of large, handsome fruits. It is vigorous and healthr, never having been affected with blight or other disease. The young trees are handsome growers, surpassed by but few varieties; the fruit is large, equaling Clapp's Favorite in size, and handsome beyond comparison; rich golden yellow, largely overspread with brilliant carmine; firm, solid, a good shipper, of good quality. Ripens with Lawson in July. A valuable early market sort and excellent for home use.

Rural New-Yorker says of Angel: "A remarkably early Pear, large and beautiful-more showy than Clapp."

Farm Journal says of Angel: "Large, handsome, solid-better than Lawson."

SENECA. Fruit a beautiful, bright yellow, with brilliant red cheek. Large, rich, juicy, buttery, melting, sprightly, vinous, of high flavor, of excellent quality; very attractive in appearance. Much admired and highly praised by all who see it. Ripens in August.

JAPAN GOLDEN RUSSET. Tree BEARS ENORMOUSLY EVERY YEAR, HAVING NO OFF YEARS. Its bearing propensities are so great that the fruit hangs in great masses, consequently, if it is not thinned, the tree will not increase rapidly in growth, and is therefore nicely adapted to smal pots or for planting close together. The abundance of thick, tough, leathery leaves of the JAPAN Golder Russer enables it to endure great heat and drought, and particularly adapts it to dry, hot climates and parched, sandy soils, where the Euro- 
PEARS, continued.

pean varieties cannot exist. It also matures its wood so perfectly that it would require very intense cold to injure it, and it is very free from blight and insects.

THE FRUIT is of a handsome, uniform, flat or apple shape, so that it may be a hybrid between the apple and Pear; of good size, 8 or 10 inches around, and becomes a beautiful golden russet color when it ripens, in September.

KIEFFER. A seedling of Chinese Sand Pear; very vigorous, free from blight, enormously productive; fruit large, golden yellow with red cheek, very handsome, good quality; excellent for canning.

LINCOLN CORELESS. This remarkable late winter Pear, so far as we are able to ascertain, is a chance seedling. It originated in Lincoln county, Tenn., near the Alabama line, and the original tree during sixty years has seldom failed to bear. Though scarcely more than a shell, it has remained free from blight and annually borne fruit. The young trees are good growers; wood dark, foliage large, healthy and entirely free from blight, leaf rust or mildew.

THE FRUIT is very large and matures late in the season, at which time it is hard and green; but when put away and kept during winter, it gradually mellows, becomes very high colored, juicy, rich, and has a very delicate, aromatic flavor. It KEEPS LONGER THAN ANY OTHER VARIETY KNOWN Or tested in its original locality, having been kept in good condition until March. The flesh is of a rich yellow tint. It has neither SEED NOR CORE, AND CAN BE PRESERVED WHOLE.

\section{GENERAL LIST OF GOOD PEARS.}

\begin{tabular}{|c|c|c|c|c|}
\hline TANDARD & XTRA, & & $\begin{array}{l}\text { er doz. } \\
\$ 200\end{array}$ & $\begin{array}{c}100 \\
\$ 2000\end{array}$ \\
\hline & First-class, 2-year, express or freight.... & 20 & 150 & \\
\hline & MEDIUM, 2-year, express or freight....... & 15 & 150 & 1200 \\
\hline & LigHT, 1 -year, mail or express $\ldots \ldots \ldots \ldots \ldots \ldots \ldots$ & $121 / 2$ & 100 & \\
\hline & FirST-CLASS, 2 to 3 -year & 15 & 150 & \\
\hline & ExTrA, bearing, 3 to 4 -year. . & 25 & 250 & 20 \\
\hline
\end{tabular}

Special quotations for large quantities.

Lawson. A healthy grower, free from blight; very productive. Fruit medium to large; beautiful red on yellow ground; remarkably attractive and handsome; flesh crisp, juicy and pleasant. Very early, ripening middle of July.

Wilder Early. A good growing, good keeping, good shipping, superior flavored, very early, handsome Pear. It holds its foliage well, and thus far has been free from blight or other disease.

Clapp's Favorite. Large, handsome, delicious; a good grower and productive.

Bartlett. A good grower, very productive and an annual bearer; fruit large, yellow, juicy, buttery and excellent; very popular.

Le Conte. Very vigorous grower, with luxuriant foliage; fruit very large, greenish yellow, smooth and handsome; juicy, fair quality; excellent for evaporating or canning. Very productive and profitable. Early.

Garber Hybrid. A seedling of Chinese Sand Pear; very vigorous and free from blight; very productive. Fruit large, round, handsome, smooth, waxen yellow; excellent for canning and preserving.

Seckel. Small, yellowish russet; rich, juicy, melting, delicious, best quality; slow grower, free from blight.
Vermont Beauty. This beautiful and valuable Pear originated on Grand Isle, Lake Champlain. Is very hardy, having endured extremely cold weather, and has never lost a bud from either cold or blight. A vigorous grower, free from leafblight, and an annual abundant bearer. In quality the fruit approaches nearer that most delicious of Pears, the Seckel, than any other Pear on the market. The fruit is, full medium size, yellow, covered on the sunny side with a bright carminered, making it exceedingly attractive and handsome; flesh melting, rich, juicy, aromatic. Ripens with and after the Seckel, and is much larger and more attractive in appearance. Cannot fail to prove a general favorite.

Anjou. Good grower, very productive and valuable; fruit large, greenish yellow, buttery, melting, very good.

lent.

Sheldon. A good size, russet; juicy and excel-

Lawrence. A good grower, with good foliage; very productive and an annual bearer. Fruit medium, canary-yellow, sweet and excellent; a good keeper.

\section{ADDITIONAL VARIETIES.}

Howell, Buffum, Belle Lucrative, Vicar, Louis Bonne, Duchesse D'Angouleme.

\section{IMPERFECT POLLINATION OF PEARS.}

IT HAS LONG BEEN KNOWN that strawberries and some other fruits gave best results when several varieties were planted together, so that the pollen of the different varieties could be intermixed; but until recently it had not been considered necessary with the larger fruits.

In spring of '93 Prof. M. B. Waite, of the Department of Agriculture at Washington, D. C., spent several days at the Pomona Nurseries, experimenting with the pollen of Pears, and found that THE POLLEN OF MANY varieties of Pears is entirely STerile Upon their own Blossoms. Bartlett is considered so, and Anjou is as sterile on its own variety as Bartlett; but the pollen of Anjou is perfectly good for Bartlett, and that of Bartlett is perfectly good for Anjou. Seckel and Duchesse are very satisfactory pollenizers. Buffum, Howell and Bosc do not need pollination from other varieties.

OUR ATTENTION has been attracted to some large blocks of Kieffers and Bartletts that, under unfavorable climatic conditions during time of blooming, would produce little or no fruit, while other orchards of Kieffers and Bartletts, having other varieties through or near them, have given much better results; and we are led to believe that in planting Kieffer orchards, they will be more productive if other varieties are planted among them.

IN ESTABLISHING ORCHARDS OF KIEFFER that are not fruiting satisfactorily, we would suggest planting some other varieties among them at a distance of every fifth row; and as it is important to have a variety that blooms early in the season, and to get immediate benefit, IT SHOULD BE A VARIETY THAT BLOOMS YOUNG. 


\section{Peaches.}

PRICES OF PEACH TREES.

Small trees by mail.

Each Per doz. $100 \quad 1,000$

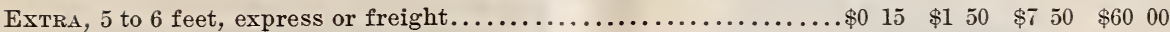

First-class, 4 to 5 feet, express or freight ................... $10 \quad 100 \quad 600 \quad 5000$

Medium, 3 to 4 feet, express or freight ..................... $10 \quad 75 \quad 500 \quad 3500$

SECOND-CLAss, 2 to 3 feet, and June buds, mail or express ......... $10 \quad 50 \quad 400 \quad 3000$

Special quotations for large quantities.

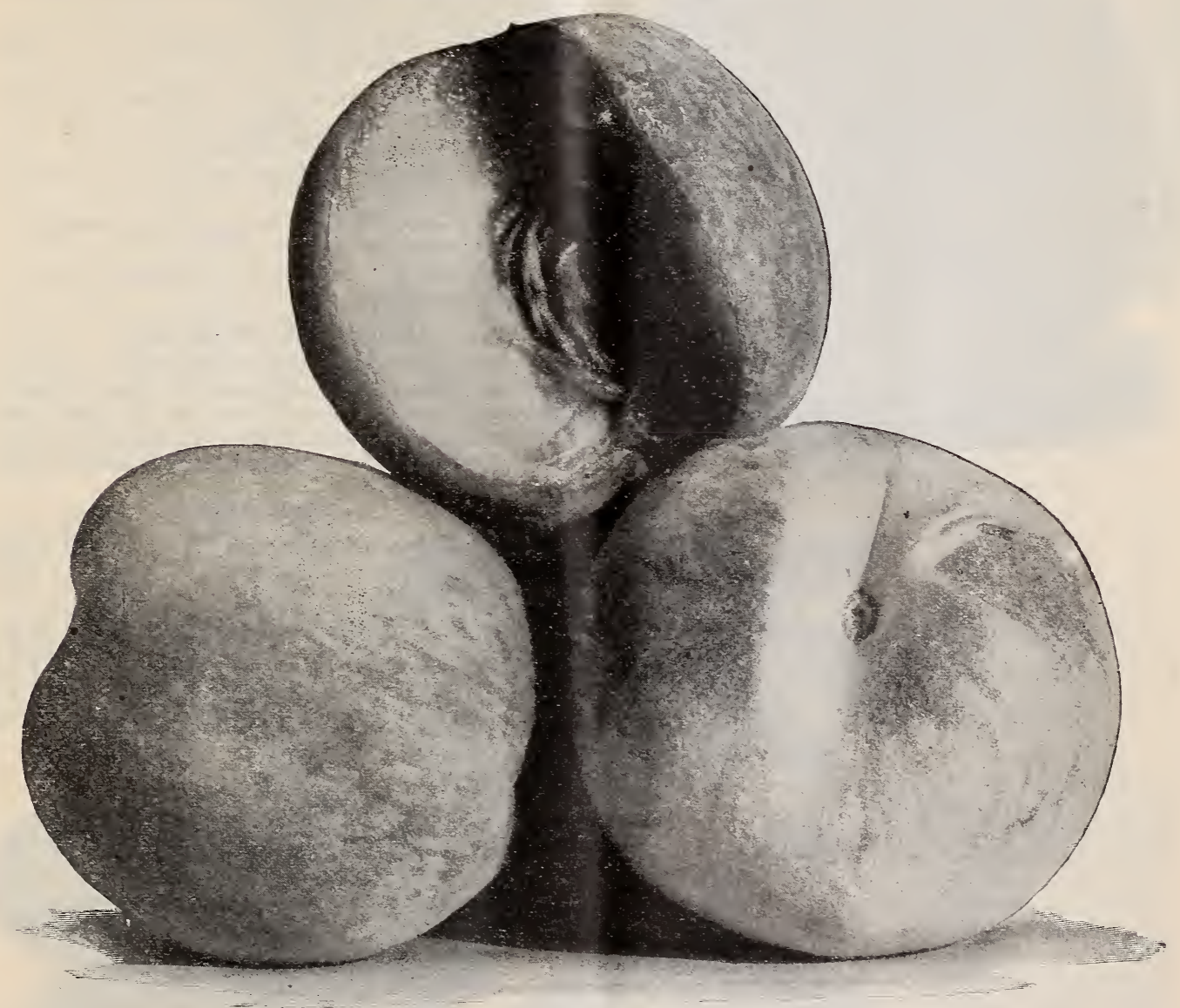

Triumph Peaches.

TRIUMPH. Fruit growers have for years been looking for a good early yellow freestone Peach. The late Chas. Downing once said: "A freestone as large, handsome, early and good in quality as Alexander would be worth a million dollars to the public." TRIUMPH FULLY SUPPLIES THE WANT. It ripens with Alexander, blooms late, has large flowers, is a sure and abundant bearer, and the tree makes a very strong growth. Several trees (2-year-old buds) produced this season over half a bushel of fruit each. The fruit is of large size, with a very small pit. Surface yellow, nearly covered with red, dark crimson in the sun. Flesh bright yellow, free when fully ripe; of excellent flavor.

CROSBY is claimed to be THE SUREST BEARER AND OF THE BEST QUALITY OF ANY PEACH IN AMERICA. The introducer says: "It is now bearing its eleventh successive crop in New Hampshire, and June-bud trees planted in Georgia in Febr'uary, 1892, produced superb specimens of fruit the first week in Jul 5,1893 . At date of writing, August 1, we have fine specimens in our office, picked two weeks ago, brought north without ice, proving it to be a SUPERB SHIPPER AND KEEPER."
Greensboro. Origin North Carolina. Recently introduced, and claimed to be earlier and larger than Alexander. Freestone.

Amsden. Medium, red, juicy; of good quality.

Large Early York. Medium, light red; juicy and rich. Freestone.

Mountain Rose. The largest early Peach. White, with red cheek; rich and very good; productive and reliable. Fréestone. 


\section{PEACHES, continued.}

LORENTZ. A FRost-PRoOF PEACH. Claimed to be superior in quality to any other Peach ripening at same time. More attractive, showing both bloom and color like an early September Peach. It has not failed to produce a full crop in the five years it has been in existence, while but one crop has been gathered in the same time from other varieties. IT Is FROST-PROOF. This season, when all others failed, Lorentz was loaded. From one foot of wood, cut for photographing,

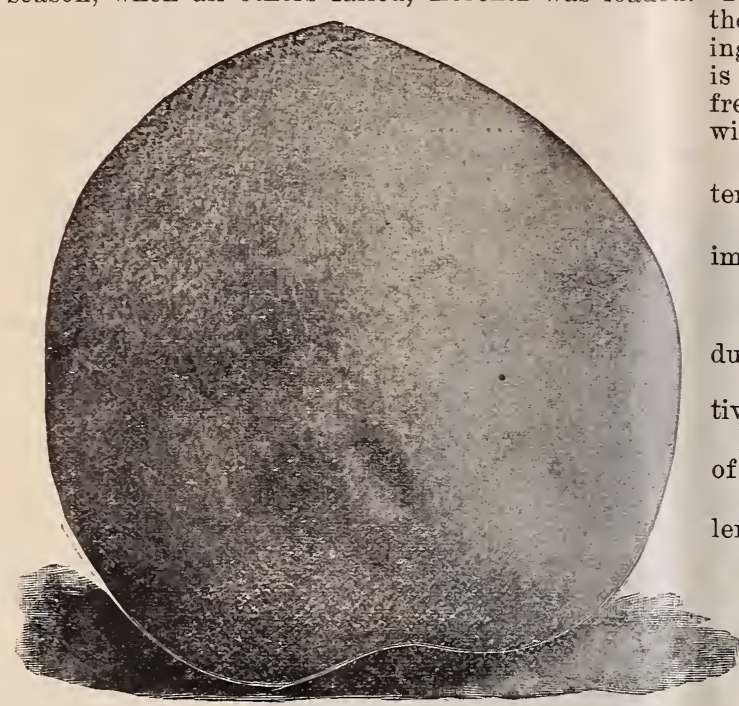

Lorentz Peach. there were taken 25 large, luscious Peaches, equaling in size Crawford Late or Wheatland. Lorentz is vellow in flesh, with bright red cheek; a perfect freestone of best quality, ripening October 25, and will keep two weeks after picked.

Oldmixon Free. Large, white, with red cheek; tender and rich; very good.

Stump. Very similar to Oldmixon, following immediately. Freestone.

Globe. Tery large, yellow; firm and excellent.

Crawford Late. Large, yellow; very productive and reliable. Freestone.

Beer's Smock. Large, yellow; very productive; good shipper.

Ford's Late White. Large, white, handsome; of good quality.

Heath Cling. ' Large, white ; clingstone; excellent for canning.

\section{ADDITIONAL VARIETIES.}

We can furnish at regular rates: TROTH'S EARLY, CrawFord's Early, Foster, WhEATLAND, WAGER, REeVES' FATORITE, WARD's LATE, Parker's Seedlixg, Salthay, Fox's Seedlixg, Chair's Choice, Peen-To, Wonderful, and ELbERTA.

\section{Quinces.}

PRICES OF QUINCE TREES.

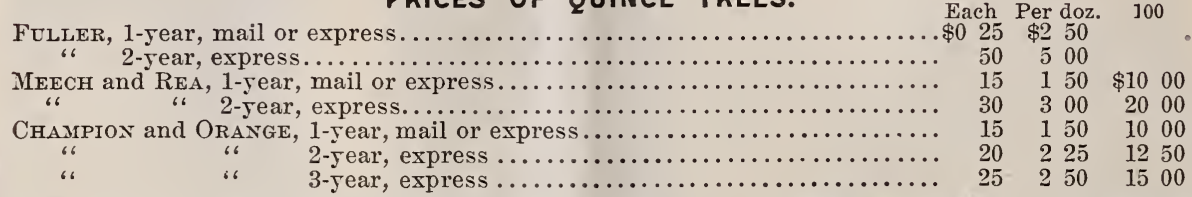

Fuller. First brought to notice by and named in honor of Andrew S. Fuller. The most reliable variety yet found, not having failed to produce a crop of the largest, handsomest and finest fruit in orer 20 years. The tree is a strong grower, with large smooth foliage, which it has retained, and produced fruit abundantly in locations and situations where all other varieties of the Quince are barren. The fruit ripens early, is of the largest size, pyriform in shape, of clear, bright lemonyellow color, highly flavored and tender.

Orange. The well-known old and popular sort; large, golden yellow; fine quality.

Rea. Seedling of Orange Quince; strong grower; fruit large and handsome.

CHAMPION. Very hardy and prolific, fruiting very young, often at two and three years old in nursery rows; fruit very large, showy and handsome; rich yellow; flesh tender, and cooks free from lumps.

Meech. A strong grower, enormously productive, and comes to bearing very young. The fruit is remarkable for its fine form and color, high fragrance and flavor; large, bright orange-yellow, very handsome; unsurpassed for cooking.

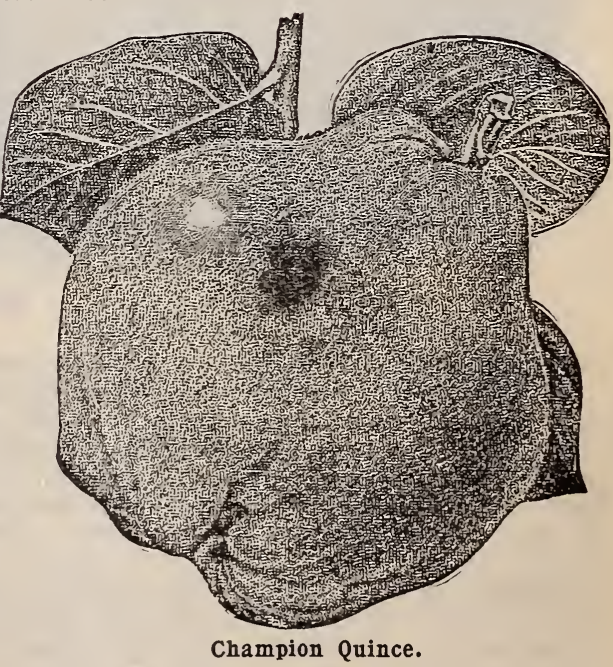

ASPARAGUS.

Columbian White. Per $100 \quad 1,000$ Conover's Colossal.$$
\text { is }
$$$$
\text { is }
$$

3 -year

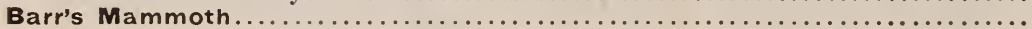

Palmetto. 


\section{Plums.}

\section{PRICES OF PLUM TREES.}

\section{Lincoln, $\quad$ Each Per doz. 100}

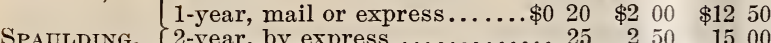

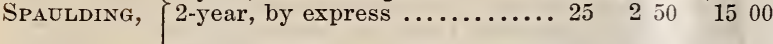
Abundance, Satsuma, Burbank, Willard,

Kelsey, Botan, Juicy, Wickson.

1 -year, 1 to 2 feet, mail or express ........... $15 \quad 150 \quad 1000$ 2-year, 4 to 6 feet, by express...............25 $250 \quad 1500$ Special quotations for large quantities.

SPAULDING. Curculio-proof. Has not failed to produce a full erop in 20 years, and is enormously productive. Fruit large, yellowish green, with marblings of a deeper green and a delicate white bloom ; flesh pale yellow, exceedingly firm, of sugary sweetness, though sprightly and of great richness. The canned fruit is superb and most attractive. The fruit has been selling' here for years at $\$ 1$ a peck. Tree as exceptional in its vigor as a Kieffer pear. Ripens early; from middle to last of August here.

THE LINCOLN. For years we have been searchto the list of cultivated varieties of the Plum, those that were prolific, handsome and of fine quality, but above everything else, for those that escape the attacks of the curculio. Our efforts have thus far resulted in bringing forward the Spaulding and Abundance and giving popularity to

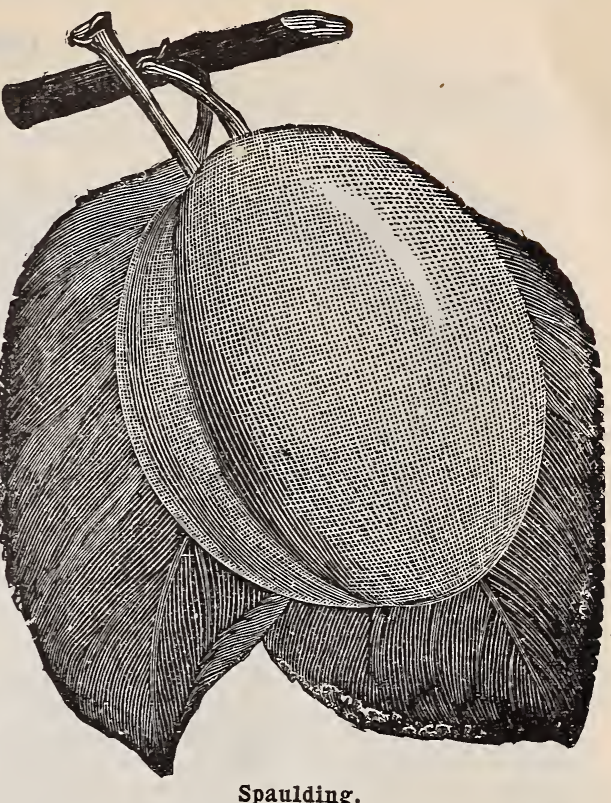

several others. We now offer the Lincols, which in several important properties is the most remarkable Plum we have yet seen. It is THE LARGEST OF ALL HARDY PLUMS, average specimens from overloaded trees measuring $2 \frac{1}{2}$ inches long, 6 inches around, and weighing 2 ounces; selected specimens weighed 4 ounces each. It is THE FINEST IN QUALITY of ANY PLUM we have ever tested, surpassing its parent,

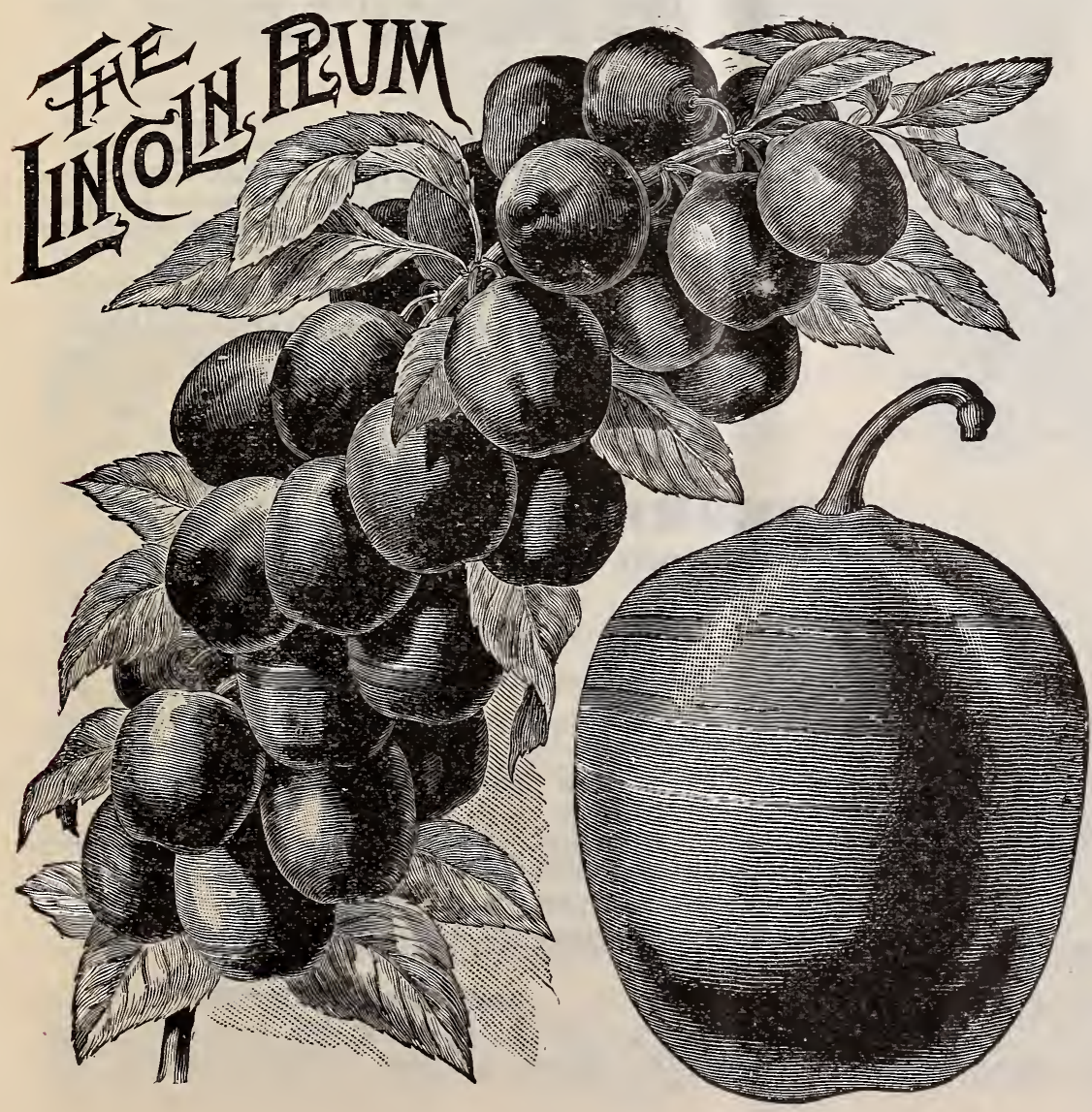
that standard of excellence, the old Green Gage ; wonderfully prolific, the Plums hanging like ropes of onions upon the branches; beautiful in form and color, very early in ripening and curculio-proof.

The fruit is reddish purple, with a delicate bloom; very bright, showy and attractive; flesh light yellow or amber, exceedingly juicy, rich, sweet, melting and luscious ; entirely free from any coarseness or toughness, parting freely from the stone. Ripens from August 1 to 15.

HEAPS OF MONEY IN IT. Mr. E. B. Good, of York county, Pa., writes : "The specimens I send you by mail are of only medium size. Specimens have been grown to weigh four ounces. The tree from which these were picked is just literally covered with Plums and standing in a stiff sod. I am sadly mistaken if there are not heaps of money in it for the market-grower." 


\section{JAPANESE PLUMS.}

WICKSON. Luther Burbank, the originator of this as well as of many other valuable fruits, con-

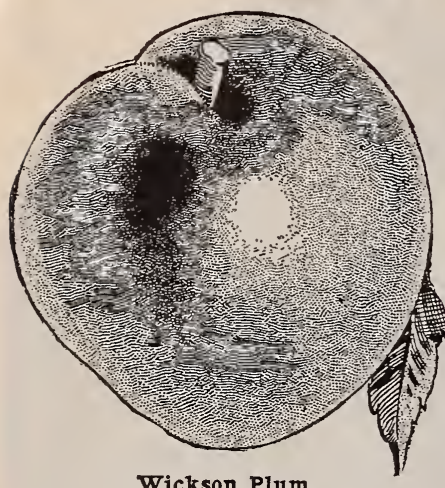
siders this the best of all cross-bred Plums, and offered the original tree for $\$ 2,500$, which evidenced his estimate of it. Fruit large, - obconical, dark crimson-purple; flesh very firm, yellow, juicy, subacid, highly flavored; pit small; clingstone; quality best. An excellent keeper. Ripens after Burbank, and is a good-keeping Plum.

ABUNDANCE. In tree and fruit unlike any other Plum. In growth it is so strong and handsome as to render it worthy of being planted as an ornamental tree, equaling in thrift and beauty the Kieffer Pear, which it even excels in early and profuse bearing. Its propensity to early bearing is such that every year, in the nursery row, the branches are bent with such a weight of fruit that they sometimes break. The curculio has no effect upon it, the eggs failing to hatch and produce the destructive grub, the same as with Spaulding. THE FRUIT is very large, showy and beautiful. Amber, turning to a rich, bright cherry color with a decided white bloom and high perfume. Season early August. Stone small, parting readily from the flesh.

JUICY. (Burbank's.) Claimed by the introducer to be "BURBANK's GREATEST PRODUCTION. The grandest Plum in existence, most beautiful, most luscious, best bearer, and best keeper." A cross between Botan and Robinson. Fruit the size of the former, three times larger than the latter, aud of perfect shape. Skin thin and transparent, light yellow, underlaid with scarlet. It has a delicious sweetness, mingled with a sprightly acid and a high, melting Plum flavor. The tree is a hardy, rank, luxuriant grower, though of dwarfish habit. It begins to bear when very small, trees scarcely three feet high often producing crops. When of fair size it is an enormous yielder and the fruit ripens early. The fruit keeps a long time after ripening, often 15 or 20 days in hot weather, without decay.

BURBANK. Crimson-purple; very handsome and rich; hardy and productive.

WILLARD (No. 2 Botan). Immensely productive; a month earlier than Abundance; of large size and quality.

SATSUMA. A purple-fleshed Plum from Japan, of very vigorous growth, with rank, dark green foliage. Enormously productive of fruit that is larger, handsomer and very much richer and betterflavored than Kelsey, hardier, and ripening 5 or 6 weeks earlier. Pit but little larger than a cherry stone. Fruits at two or three years of age. Considered the most valuable of Japan Plums.

\section{NATIVE PLUMS.}

\section{Price, 20 cts. each, $\$ 2$ per doz., \$15 per 100.}

Since it is impossible to grow the more delicate varieties of European Plums in some unfavorable localities, it is gratifying to us to be able to offer to our customers in such sections a succession of native American Plums that can be relied on for certain crops of luscious fruit, all of which are considered curculio-proof.

Milton. The earliest Plum in the world; three weeks earlier than Wild Goose, larger, more productive and of better quality.

Wild Goose. Large, rich, crimson, very productive and profitable.

Newman. Large, red, productive and reliable.

\section{ADDITIONAL VARIETIES.}

Coe's Golden Drop, Imperial Gage, Marianna, JefFerson, RichlaAN, GreEN GaGe, GerMAN Prune, Shipper's Pride and Pond's Seedling. Price, first-class, $4 \frac{1}{2}$ to 6 feet, 20 cts. each, $\$ 2$ per doz., $\$ 15$ per 100 .

\section{CHERRIES. PRICES OF CHERRY TREES.}

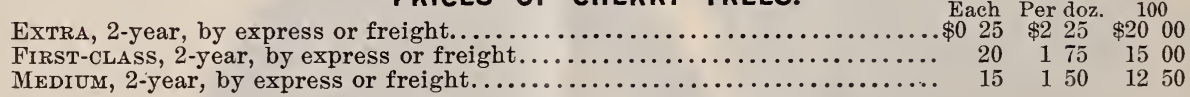

\section{Special quotations for large quantities.}

Early Richmond. Medium, red, acid; productive.

May Duke. Large, red; rich, good quality.

June Duke. Large, dark red, excellent.

Montmoreney. Large, bright red, sour; late and valuable.

Belle de Choiey. Medium, amber; very good.

Black Eagle. Large, heart-shaped; dark, rich and good.

Black Tartarian. Large, juicy, rich, sweet, delicious.

Governor Wood. Large, yellow, with light red cheek; delicious.
Napoleon. Very large, light with red cheek; sweet and good.

Yellow Spanish. Large, yellow; rich, sweet and good.

Oxheart. Very large, light with red cheek; solid, meaty, rich and excellent.

Downer's Late. Medium, red; rich, luscious.

Mercer. $35 \mathrm{cts}$. each, $\$ 3.50$ per doz.

\section{ADDITIONAL VARIETIES.}

We can also furnish Elton, Windsor, OLIVET, Dye Horse, Empress Eugenie, English MoRELLO, etc. 


\section{THE DWARF ROCKY MOUNTAIN CHERRY.}

Is closely related to the Eastern Sand Cherry, Prunus pumila, but differs from it in a degree that would seem to warrant the opinion that it is a distinct species, and noted botanists are unable to classify it. It is entirely hardy, having withstood $40^{\circ}$ below zero unharmed in either fruit, bud or branch.

Chas. E. PENNOCK, of Colorado, says: "It is the most productive fruit of which I have any knowledge. I have picked 16 quarts of fruit off a 3 -year-old bush. I have picked 80 cherries off a branch 12 inches long of a 2-yearold bush. The fruit is jet black when ripe, and in size averages somewhat larger than the English Morello, season of ripening being after all others are gone. In flavor it is akin to the sweet Cherries, and when fully ripe, for preserves or to eat out of hand, it has no equal in the line of pitted fruits, and is conceded superior to any fruit grown in this section. It has the best system of roots of any shrub or tree

I have ever planted, which accounts for the wonderful productiveness of plants at such an early age. It bears every year, and is as prolific as a currant bush. Grows to a height of 4 feet, and has never been affected by insects, black knot or other disease. In addition to its immense productiveness of luscious fruit, valuable for pies, sauce, or for market purposes, its mass of pure white flowers makes it a handsome flowering bush."

The bushes grow 4 to 5 feet high and begin to bear luscious Cherries the second year. As ornamental trees or for hedging there is nothing more delightful in their line from the time they blossom in May until the fruit ripens in August, and their beautiful deep green, willow-like leaves remain very late in fall.

\section{GOOD OPINIONS FOR THIS CHERRY.}

"The fruit is not astringent, is larger than the Early Richmond Cherry, and not so tart."

"Cherry five-eighths of an inch in diameter, nice, fat and delicious.

"It is very hardy and is found in rery exposed posi-

tions in British Columbia. It does not send up suckers or sprouts from the roots."

"It is as hardy as a mountain pine, as easily cultivated and propagated as a gooseberry, as prolific and steady a bearer as a currant bush."

Price for Rocky Mountain Cherry.

1-year trees, mail or express, $10 \mathrm{cts}$, each, $\$ 1$ per 2 -rear trees, express, 15c. each, $\$ 1.50$ doz., $\$ 10$ per 100. doz., $\$ 5$ per 100 .

3-year trees, $25 \mathrm{c}$. each, $\$ 2.50$ doz., $\$ 15$ per 100 .

\section{PAPA W-(Custard Apple, Northern Banana).}

A beautiful, symmetrical lawn tree with dark green, handsome foliage; is best known in the valley of the Mississippi and tributaries. Hardy as far north as New York on the Atlantic coast, and much esteemed in the south. The fruit is yellowish green, about 3 inches long, and in flavor so closely resembles a custard as to suggest the name Custard Apple. Price, small trees, by mail, 25 cts. each; larger, by express, 50 cts. each. 


\section{Apricots.}

RUSSIAN APRICOTS are claimed to be in every way superior to American varieties in early bearing and quality of fruit, as well as hardiness of trees and freedom from all disease, worms and insects. In extremely cold locations, where the mercury falls to $46^{\circ}$ below zero, the Russian Apricots have passed through the winter safely, while the Amercans by their side have been killed to the ground. The leading and best varieties are J. L. Budd, Alexaydria and CATHARINe. Price, mail or express, 20 cts. each, $\$ 2$ per doz.

AMERICAN APRICOTS. Not so hardy as the foregoing, though if planted on the north or west side of a building or wall, a crop is almost certain. Price, mail or express, 15 cts. each, $\$ 1.50$ per doz.

Early Golden seems to be a favorite owing to its great productiveness and attractive fruit of delicious quality.

Moorpark is one of the largest, with beautiful red cheek; flesh firm, juicy, rich.

JAPANESE APRICOTS. Japan appears to abound in delicious fruits, and among the most remarkable of recent introduction are the Japanese Apricots, far excelling the American or Russian in vigor of growth, hardiness and excellent quality. We can fur-

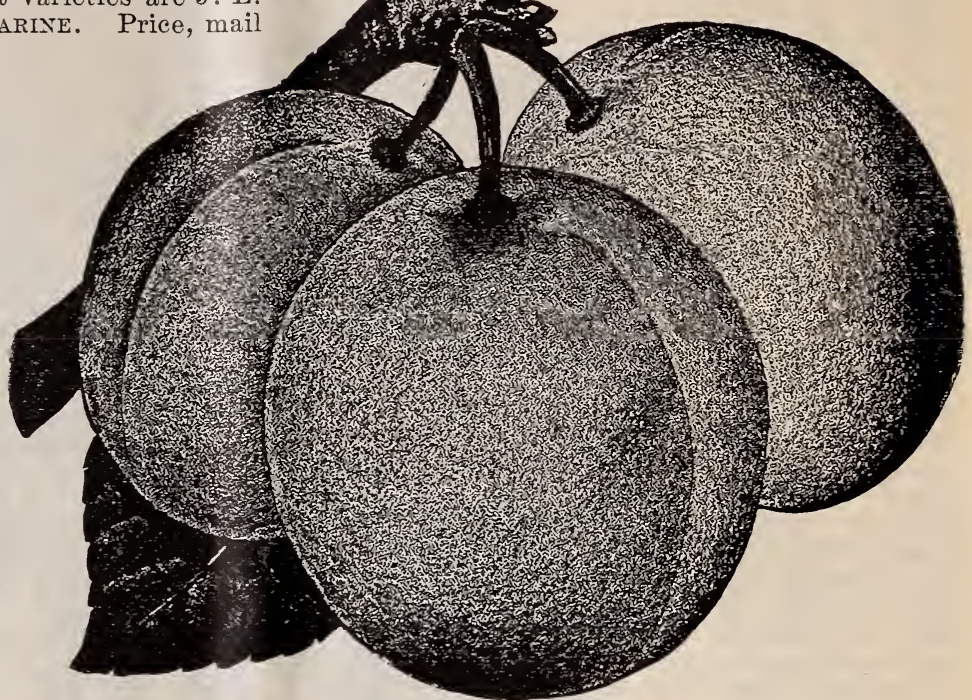

Japanese Apricots. nish several varieties, including only the leading and most desirable sorts. Price, mail or express, 20 ets. each, $\$ 2$ per doz.

\section{A NEW HARDY ORANGE.}

This is the most hardy of the Orange family, and will stand our northern climate with little or no protection, and is also desirable for pot culture. In the parks of both New York and Philadelphia it is growing luxuriantly, and blooming and fruiting profusely. You can have an Orange tree growing, blooming and fruiting on your lawn or yard. It is a dwarf, of a low, symmetrical growth, with beautiful trifoliate, glossy green leaves, and an abundance of large, white, sweet-scented blossoms, and borne

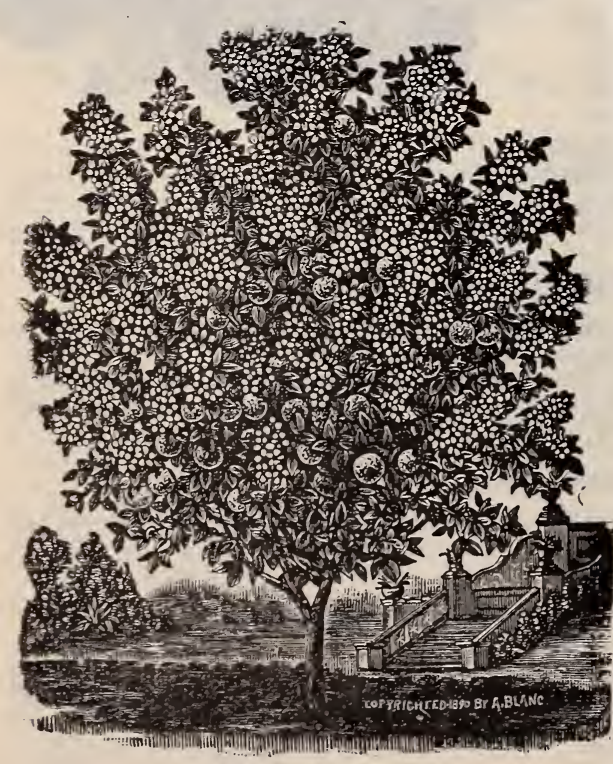

Trifoliate Orange. almost continually. The fruit is small, bright orangered in color, having a peculiar flavor; of no value for eating, though it may prove useful in making lemonade, as the fruit is as acid as a lime. It is best suited for open ground culture, as it is deciduous and drops its leaves in the fall, and cannot be induced to make much growth in winter, even in a greenhouse, though it will not drop its leaves if kept from frost. It blooms very profusely in spring and early summer, but after the fruit begins to form, blossoms are not plentiful. Our picture represents a young tree about 4 feet high, as it appears when in bloom nnd when it fruit, but the flowers and fruit do not appear-together to the extent there shown. The fragrance produced by a tree in bloom can be appreciated only by those who are familiar with the delicious perfume of the orange blossom. We predict for this tree a great future. It makes a handsome hedge. Price, 2 years, $1 \frac{1}{2}$ to 2 feet, 10 cts. each, $\$ 1$ per doz., $\$ 2.50$ per $100, \$ 20$ per 1,000 .

\section{AMERICAN PERSIMMON.}

The Persimmon of our woods is a very ornamental tree, especially when in fruit. It is a hardy, prolific bearer, and free from insects. If allowed to remain on the tree exposed to frost the fruit becomes very sweet and palatable. Price, mail or express, 25 cts. each, $\$ 2$ per doz. 


\section{DOWNING EVERBEARING MULBERRY.}

This not only makes a handsome lawn tree, but produces delicious berries, beginning to fruit at 4 and 5 years of age, and continuing in bearing 3 to 4 months of the year, making it very desirable. The foliage of Mulberries is valuable for silkworms, while the fruit makes excellent chicken feed as well as a fine table dessert. The late Henry Ward Beecher said that he regarded the Mulberry as an indispensable addition to every fruit garden, and that he would rather have a Downing Mulberry tree than a strawberry bed. The Downing is of the highest quality, and ought always be planted instead of the miserable little "Russian" mulberries so widely advertised, which have fruit of no quality at all, and of only the most trifling size. Price, by mail or express, 25 cts. each, $\$ 2.50$ per doz., $\$ 15$ per 100 .

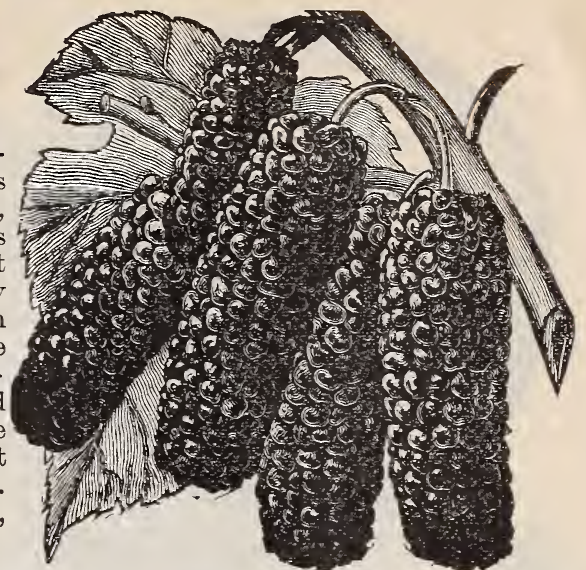

Downing Mulberry.

\section{Nuts and Nut Trees. PRICES OF NUT TREES.}

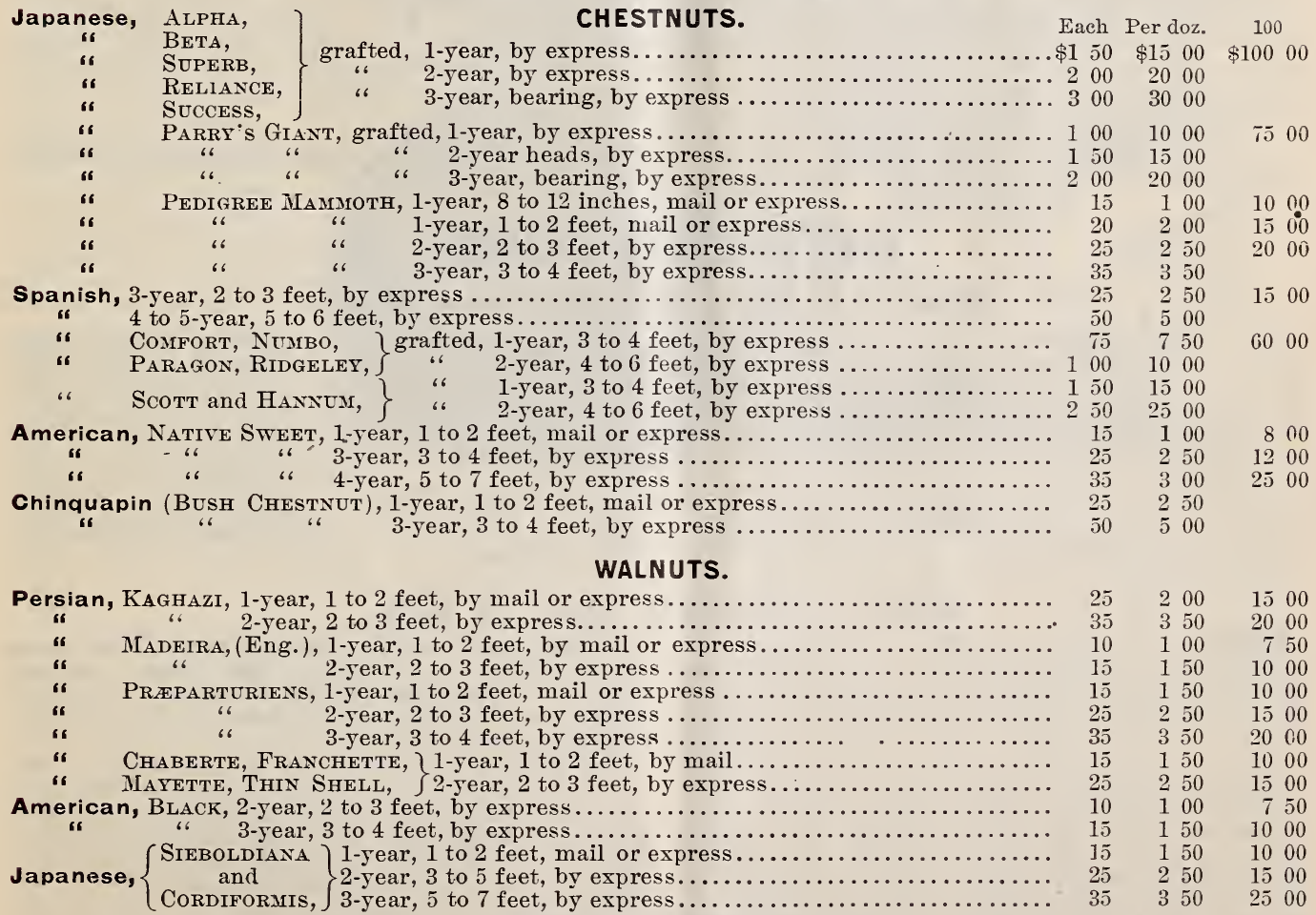

OTHER FAVORITE NUTS.

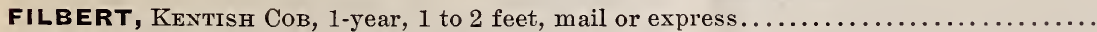

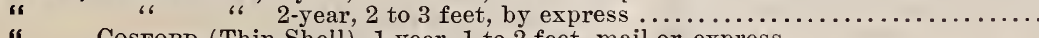

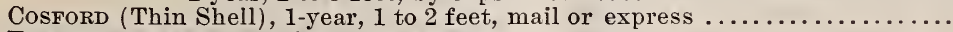

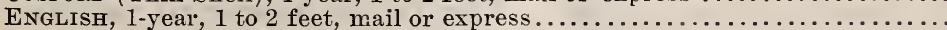

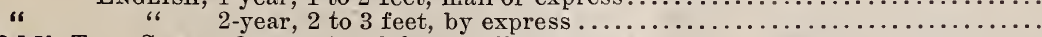

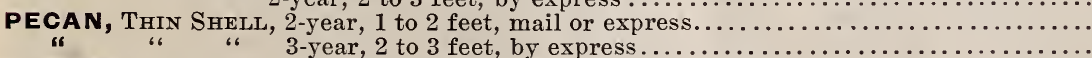

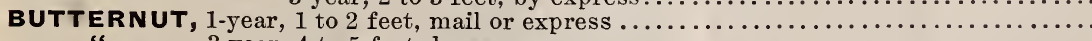

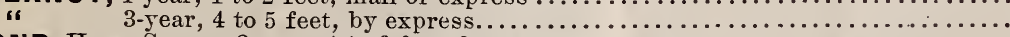

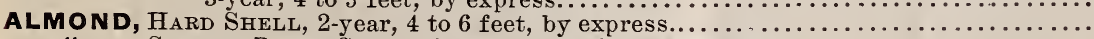

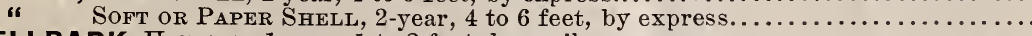

SHELLBARK, Hickory, 1-year, 1 to 2 feet, by mail or express . . . . . . . . . . . . . . . . . . . . . . .

Special quotations for large quantities. 

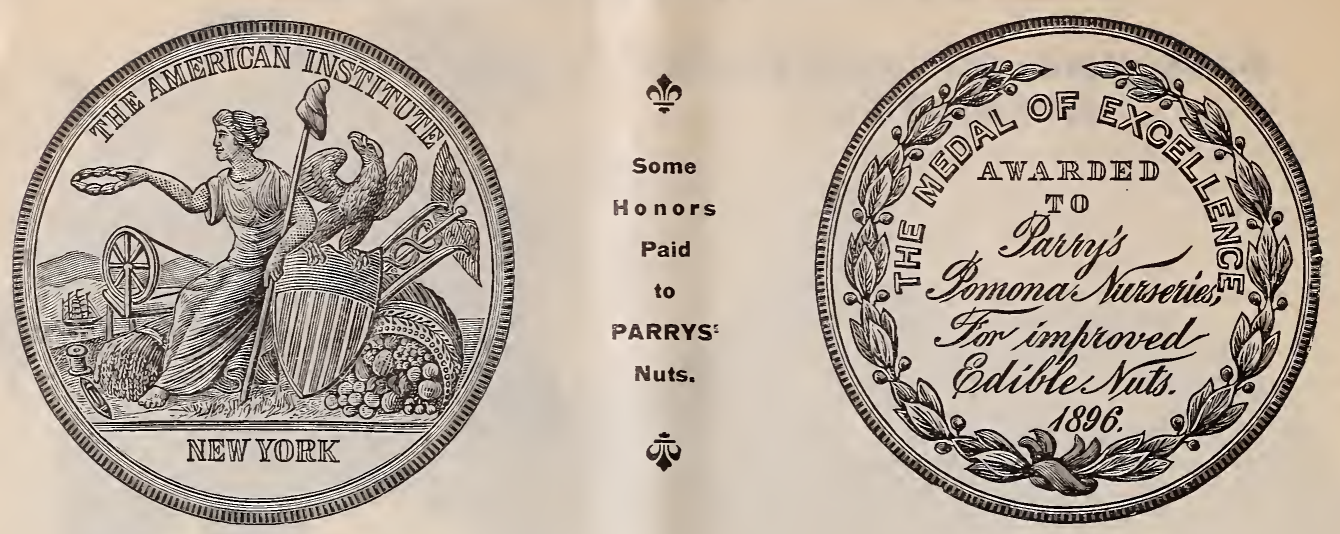

From THE RURAL NEW-YORKER:

\section{NOTES FROM AMERICAN INSTITUTE FAIR.}

"One feature of the American Institute Fair that attracted much attention was the display of nuts made by Parrys' Pomona Nurseries, Parry, N. J. It comprised 18 varieties of chestnuts, French, American Black, Persian, English, Madeira and Japan walnuts, hickory nuts, pecans, filberts and butternuts. It showed the advance that has been made in nut growing, and the interest manifested by visitors in the exhibit showed that the public are anxious to learn about the subject. The size of several of the varieties of chestnuts was a revelation to many. The quality of the nuts was left to the imagination, as 'hands off' was the injunction. Yet some had sadly depleted the collection, the superintendent saying that visitors would steal them in spite of everything."

For which display we were awarded "The Medal of Excellence ;" also, a special Diploma for a highly meritorious exhibit of improved edible nuts.

\section{NUT CULTURE.}

\section{Plant Nut Trees Instead of the Nuts.}

Until recently nut trees have been but little grown in nurseries, and in consequence all transplanted trees have come from forests, or where they have come up and grown naturally, and having but little or no fibrous roots, their transplanting has been attended with much uncertainty, giving the impression that they could not be transplanted, but that to insure success the seed must be planted where the tree is intended to stand, which is erroneous, and has deterred many from engaging in this profitable industry. Many of the nut bear- ing trees, when grown in nurseries, are well supplied with fibrous roots, and can be transplanted as safely as an apple tree. Thus the planter has the benefit of the three or four years' growth in the nursery over that of planting the seed, has no worry over the uncertainty of their coming up regularly, and spends no time, care and attention in getting them properly started. We therefore advise our customers to always plant the trees, if they can be had, and save three or four years' time.

\section{Notes on Different Kinds of Nuts.}

Pecans. The impression that the Pecan can be grown only in certain favorable, moist locations is rapidly being dismissed, as the trees are being continually discovered throughout the middle and western states in locations which have not been considered favorable to their growth. Here in Burlington county, New Jersey, are a number of large, handsome trees, 2 to 3 feet in diameter, on high, dry ground, and producing annually 5 to 6 bushels of delicious thin-shelled nuts. A writer in the American Agriculturist states that "they can be grown wherever the hickory thrives." The wild pecans begin bearing at six years of age; at ten they yield 4 to 5 bushels, and increase their yield with age. The nuts sell rapidly at $\$ 4$ to $\$ \bar{y}$ per bushel. The tree is hardy, tough, free from blight, insect scales or any of the usual ailments common to orchard trees.

The Chestnut is also very valuable, not only for timber purposes, but for market. Of the improved varieties of large nuts, 2 to 3 bushels per tree is but an ordinary yield, and as they come to bearing at 2 or 3 years of age, or as young as a peach tree, and the nuts sell at 25 to 40 cents per quart, the profits must be very gratifying and the business pleasant and popular. When the culinary uses of the Chestnut are more generally appreciated in this country, as they are in Europe, the demand for those of large size will be immense. European cooks know how to utilize them in a number of ways.
A Customer's Report-"May 30, 1891. This spring we ordered of you a list of NuT TREes. Among them was a Mammoth Japan Chestnut. Though a small tree, it now has seven clusters of blossoms on it, very much to my surprise."

The Rural New-Yorker, Aug. 29, 1891, states: "The 'aragon Chestnut tree, planted in spring, 1888, and now about 9 feet high, is bearing 43 burs. Another, planted in 1889, and 7 feet high, bears 7 burs. A Reliance Chestnut tree, but 2 feet and 2 inches high, bears 3 burs. It bore several the year before in the nursery row."

Mr. Forest Cory, of Enfield, N. H., states in American Gardening: "The new Japan Chestnut Reliance was not hurt by the last severe winter. One tree, $3 \frac{1}{2}$ feet high, bears 10 burs."

THE JAPAN MAMMOTH CHESTNUT is among the most valuable recent introductions from Japan, and although it revels in dry, sandy soil, yet it adapts itself to almost any conditions, has proved hardy in extreme cold climates, and flourishes in the south and southwestern states. It is quite distinct from the European varieties, being hardier, and the nuts are of superior flavor and sweetness. The leaf is long and narrow, like a peach leaf, dark green in color, making a very ornamental lawn tree. It comes to bearing at 2 to 3 years of age, and while yet in the nursery rows, 3 to 


\section{NUT CULTURE, continued.}

4 feet high, trees are heavily laden with nuts of enormous size, measuring 4 to 6 inches around and running 3 to 7 in a bur. Their early bearing and great productiveness of such enormous nuts are the wonder and admiration of all who see them.

The value of Chestnuts and profits of their culture DEPEND VERY MUCH ON THEIR EARLY RIPENING, as large Chestnuts marketed in September and early October will bring $\$ 10$ to $\$ 15$ per bushel, while late in October and Norember the price will drop to $\$ 6$ or $\$ 8$ per bushel. Our Japan Mammoth has the fortunate feature of MATURING VERY EARLY, without the aid of frost to open the burs, and is hardy in northern New York.

\section{Chestnut Culture.}

The following paper wa read before the Gloucester County Farmers' Institute, November 19, 1897, by Charles Parry, of Parry, Burlington county, N.J.:

"There are aNNUALLY IMPORTED into the United States from southern Europe many thousand pounds of Chestnuts. Over one and a half millions of dollars are paid every year by this country for imported nuts, of which a considerable portion are Chestnuts. Every pound of these Chestnuts could and should be grown at home. There are some imported articles, such as tea and silk, for instance, that had better be grown abroad. Although we have soil and climate well adapted to the production of these staples, yet the labor cost is so great in these articles that it is good economy to avail ourselves of the cheap labor of other countries and

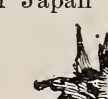
1
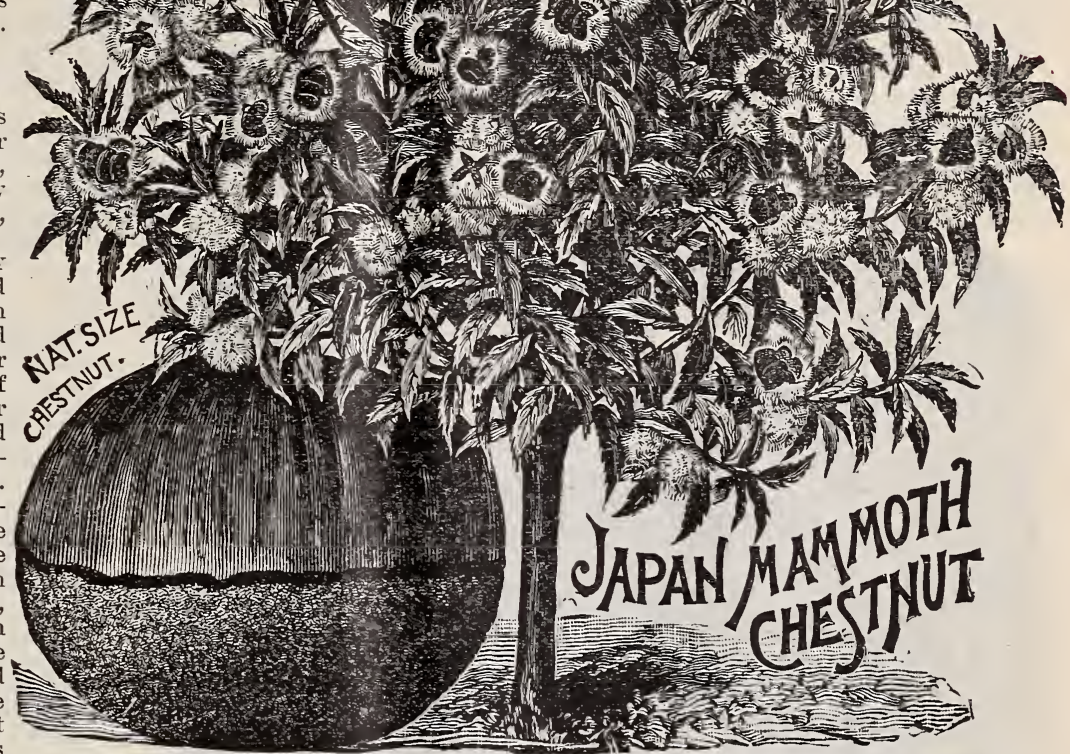

JAPAN MAMMOTH CHESTNUT TREE, four years old, at Pomona Nurseries, producing four quarts of mammoth nuts.

produce them abroad, employing our own labor in a field that will return many times what it would in tea or silk.

'THIS DOES NOT APPLY TO THE PRODUCTION OF CHESTNUTS. There are very few farm products that will yield so large a return for the capital and labor employed as Chestnuts. And we should not only supply our own markets, but should export enough to supply England, Germany and northern Europe. Why is it that farmers are so slow to arail themselves of the possibilities of this crop? It must be because they do not like to make money easily. They will spend time, labor and money growing melons, that nust be picked and marketed every day, and sometimes twice a day, to prevent spoiling, and then, if they are not sold promptly, will spoil anyway. Such crops which, after they have been grown at great expense, are liable to be swept away by millions of lice, or, if the crops are full, are liable to sell at a price that leaves the farmer in debt. Crops of this kind, I say, farmers delight in; yet they especially avoid Chestnuts, a crop that has none of these disadvantages, and will pay many times better; a crop which, when once planted, is there certainly for many generations, and will annually yield an immense revenue without cultivation, without manure, almost without care, being in this respect like a government bond, from which you annually clip coupons, leaving the principal untouched to go on producing revenue indefinitely.

"SUPPOSE FARMERS could secure a contract from a grain merchant to take all the corn they could grow every year at $\$ 3$ per bushel. They would tumble over each other to secure the contract, and would put their whole farms in corn. Yet they must plant and cultivate corn every year, and this, too, at the busiest time of the year. While Chestnuts will yield as many bushels per acre as corn and sell for more, they are planted once in a lifetime and the improred varieties will hardly sell as low as $\$ 3$ per bushel for a generation to come. In addition, Chestnuts may be grown on ground so hilly and broken that it would hardly grow corn at all.

"ANOTHER ADVANTAGE OF THIS CROP is, that the only work required on it, the gathering and marketing of the nuts, comes at a time of year, September and early October, when most other farm work is not so pressing. Nuts are not perishable, like melons. If not gathered to-tlay, to-morrow or next week will do. Neither must they be sold as soon as shipped, but can be kept for days, put in storage for weeks, or shipped thousands of miles to a better market. Again, at this time of year, when the receipts of the farm are apt to be light, Chestnuts makes a welcome addition to the market returns.

"MANY FARMERS are not yet ready to plant their level fields in Chestnut trees, but on most farms there are ravines and hillsides well adapted to Chestnut culture, and on every farm there are lanes, headlands and roadsides which, if set in Chestnuts, would pay as well or better than the best cultivated land on the farm. What an amount of food would be produced if all the maple and other shade trees along our roadsides were bearing Chestnuts! The Chestnut furnishes ample shade and at the same time rields a valuable food. At the present prices of Chestnuts they are more of a luxury than a 
CHESTNUT GULTURE, continued.

food; yet the time is coming when they will be used as a standard food and the demand will be unlimited.

"OF ALL TREE PRODUCTS of our country the pecan, walnut and chestnut are the only ones suitable to replace wheat and other grains as food. Of these the pecan and walnut are too oily to make good flour, so that the Chestnut alone is capable of yielding a flour that can make a fair substitute for the cereal grains.

"CHestnut FlovR is largely used in southern Europe for bread, cakes and pies. The nut is also largely boiled whole and eaten as a vegetable. It is too high priced to be used in this manner in this country. But as the Chestnut yields as many bushels per acre as either wheat or product. The time will come when all our mountain slopes and steep hillsides will be covered with productive groves of Chestnuts like those of Italy. This will be many years in the future, and until that time there will be abundant opportunity for progressive farmers to literally coin money out of this industry.

"In Planting Chestinuts care must be taken to set them in congenial soil, or failure is apt to result. The ous well-drained sub-soil. A heavy, sticky clay soil with an impervious wet sub-soil will not answer. Hillsides and sloping ground, where the water drains quickly away, suits this tree well.

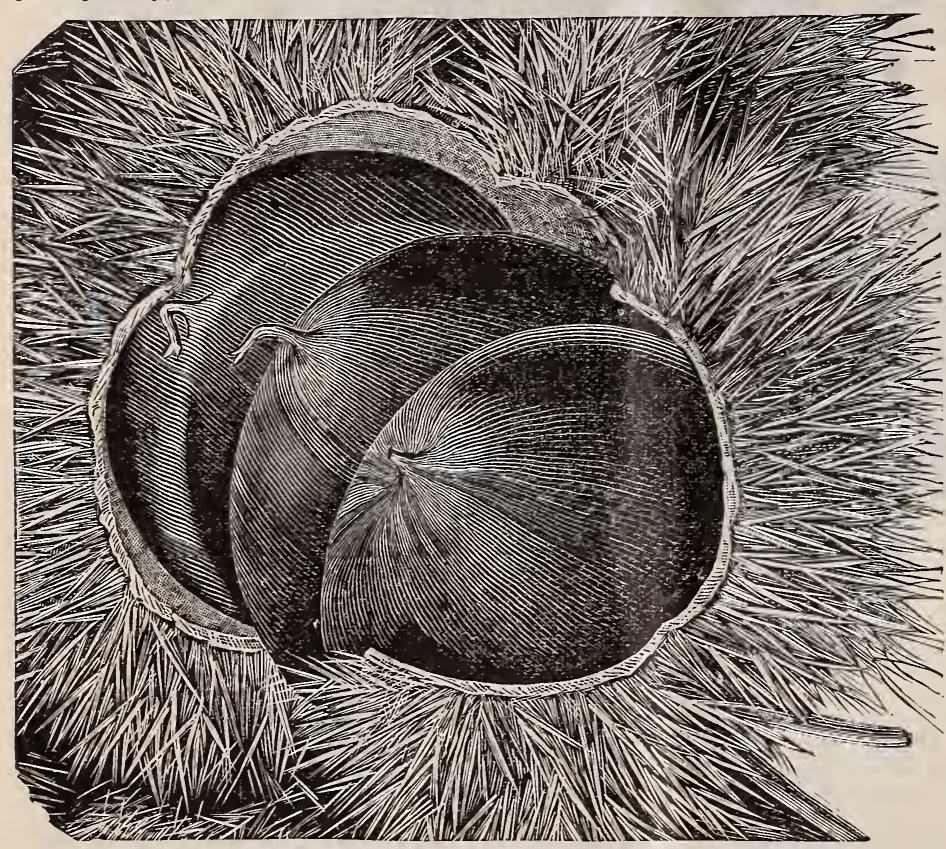

Japanese Chestnut, Parrys' Superb. (For description, see page 18.) corn it must eventually take its place as a staple food Chestnut does best upon an open soil, with a deep, por-

poor color, and fuzzy appearance make the nuts sell for low prices in the market. There are some seedlings that promise to be improvements in this respect, but at present commercial groves are composed almost entirely of Spanish and Japanese varieties. Of these the earliest to ripen, and also the largest, is the Japanese. The skin of the Japanese varieties has a much more bitter taste than either the Spanish or American varieties. This bitterness, however, largely disappears in cooking and in drying. There are also some varieties of the Japanese strain that are claimed to be equal in quality to the American; and in the future we may expect to get seedlings from the Japan strain crossed with American pollen that will produce nuts equal to American varieties in quality, while retaining the large size and extreme earliness of the Japanese.

"There ARE MANY Japan strains, all of which are early and profitable. As a few are better than many, I will name some ripening in the order named:

"ALPHA is tho first to open. It is large in size, 2 and 3 in a burr, productive; opens September 5 to 10 ; brings the highest market price.

"RELIANCE. A very early bearer; nuts large and uniform; very productive; ripens after Alpha.

"SUPERB. Very productive, running 3 nuts to the burr; ripens after Reliance.

"GIANT. The largest Chestnut, measuring 7 inches in circumference; smooth, dark, handsome; ripens after Superb.

"The Spanish strain ripens after the Japanese. The trees are largegrowing, and in planting require more room than the Japanese. There are many profitable varieties of this strain, among the best of which are Numbo, Paragon, Ridgely and Scott. These ripen after the Japanese, and prolong the season well into October.

"The PROFIts OF Chestnot GROWING at present are very large. As much as $\$ 14$ per bushel has been realized from the first consignment of Chestnuts sent to New York. From this figure the price rapidly falls to $\$ 10$ and $\$ 8$ per bushel, at which figure large quantities can be sold in New York. New York is a much better market for the earliest nuts than Philadelphia. Philadelphia will not use many nuts above $\$ 8$ per bushel, and large supplies soon reduce the price to $\$ 6$ and $\$ 5$ per bushel. Chestnuts can be produced for less than wheat, showing how profitable these figures are. After a grove once comes into bearing the expenses thereafter are very light. The original tree of Ridgely has produced in one year $\$ 55$ worth

"The QUESTION OF varieties is also of vital importance. A grove of seedling Chestnuts is of no more value than an orchard of seedling apple trees. Perhaps one out of a hundred may be of value, while ninety-nine will be of little account. Besides a grove of seedlings will be 10 to 15 years coming into profit, while grafted trees begin to bear the second year from the graft. Again, it Is IMPORTANT to have all the trees ripening at one time close together, so as to save time in gathering. Also, It IS BEST TO HAVE MOST OF YOUR TREES OF EARLY VARIETIES, so as to market them while the price is high. None of these objects can be attained with seedling trees. Again, seedlings vary as much in productiveness as in any other point, so that while some might yield well, the vast majority would probably be worthless for profit, so that it would be time and money lost to grow any but grafted trees of the best varieties.

ThERE ARE THREe GROUPS of Chestnuts in cultivation: American, Spanish and Japanese. The American strain, while sweeter than the others, has yielded few, if any profitable market varieties. Their small size, of nuts. The Hannum tree in one year returned its owner $\$ 57$. Judge Scott stated that he sometimes realized more profit from one tree of the Scott Chestnut than from the whole field of wheat in which it stood.

"BY PLANTING 30 FEET APART, we would have 48 trees per acre. A yield of 2 bushels per tree would be a moderate crop, and if the nuts sold at $\$ 5$ per bushel, would yield $\$ 10$ per tree, or $\$ 480$ per acre. This would be a large yield and a large price for common American nuts, but it is not a large estimate for the best Japanese or Spanish varieties. Cutting the price to $\$ 3$ per bushel would still give a yield of nearly $\$ 300$ per acre, and there are very few crops that can be depended upon to produce this amount per acre, even those costing far more in planting and cultivation. Occasional yields of such crops as celery, strawberries, onions, etc., surpass this yield, but it must be remembered that these crops can only be grown in limited quantities at great expense for fertilizers, cultivators, labor, etc. while Chestnuts may be grown by the hundred or thou- 
CHESTNUT CULTURE, continued.

sand acres, with little eare beyond gathering. The product is not perishable. It is a staple product, like wheat or corn. It may be shipped to distant cities foreign countries.

"There are Chestnut groves in Europe hundreds of years old still yielding annual crops of nuts. The famous Chestnut tree on Mt. Etna is supposed to have been bearing nearly 2,000 years, and it still bears annually.

"WHAT BETTER INHERITANCE can a man leave his children than a bearing grove of improred Chestnuts or how can he so easily add a permanent value to his estate as to plant 50 or 100 acres out in Chestnuts Nor is it necessary to have cheap land in order to accomplish this. I know of one farm of 120 acres worth $\$ 300$ per acre, that was set last spring entirely to Chestnuts. Such a plantation is better as an inheri tance than stocks, bonds, or even life insurance. Stocks fail to pay dividends, bonds default on their interest. the officers of insurance companies sometimes make away with the funds, and the companies fail. But as the seasons roll around the Chestnut vields its crop of nuts, and while there is a demand for food the crop will sell at a paying price. The rise or fall of the gold or silver standard would carry terror to the possessors of many kinds of wealth, while a revolution might destroy the value of even Government bonds, but nothing can destroy the demand of the human race for food.

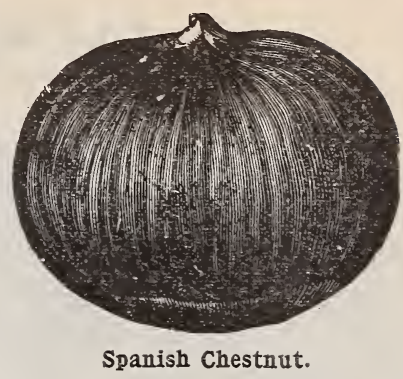

"President Berckmans once related to me the story of a friend of his who was a wealthy planter before the war. The war swept away all he had-slares and everything, except a grove of pecans, and by the receipts of this grove he was now supported comfortably with no other effort than to yearly gather the nuts. What the pecan is to the south the Chestnut is to the north, and the possessor of a large grove of these nuts has an inheritance, the value of which cannot be estimated. It can be safely said that as long as he keeps the grove, the grore will keep him."

Our Pedigree Chestnuts, described below, wil "keep" the planter royally.

\section{PARRYS' PEDIGREE CHESTNUTS.}

SINCE OUR FIRST IMPORTATION of Japan Mammoth Chestnuts, by a careful selection of seed from trees yielding in abundance nuts of large size, good form, good quality, and ripening early, we have produced a VERY SUPERIOR STRAIN OF THIS VALUABle CHESTNUT, that can be relied on to bear large, handsome and desirable nuts.

Pedigree Japan Mammoth Chestnuts. From among thousands of these we hare selected a few of rare value, their special features being YoUNG FRUITING, GREAT AND UNIFORI ANNUAL PRODUCTIVENESS, LARGE AND ATTRACTIVE NUTS OF GOOD QUALITY, RIPENING EARLY, all of which they possess in a remarkable degree. They are much larger than any of the American, French, Spanish or Italian varieties. They begin bearing much younger, one year grafts being often set with nuts; ripen much earlier, which is of vast importance to the market man; are much more productive, and are brighter, smoother nuts, free from fuzz, which renders them more attractive and salable. We have fruited them several years, and they have never failed to produce good crops, having no off years.

The JaPan Chestnuts, like the Spanish, have a bitter skin, which should be removed before eating raw, when the kernel beneath will be sweet and good. The bitterness of the skin will disappear in cooking. Seedlings grown from these LARGE SELECTED NUTS seldom fail to produce large, fine nuts at three or four years of age.

Parpys' Japan Giant. In offering both the Japan Chestnuts, Parrys' and Pedigree, we wish to

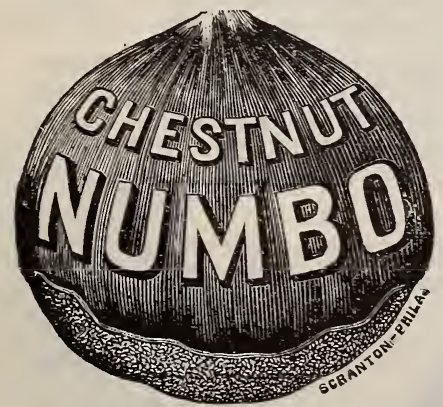

(For description, see page 19.) impress upon our customers the advantage of the particular strain of varieties we are propagating over those generally offered, which, as a rule, are imported. Our strain of JAPAN GIANT, Parrys', is grafted by us direct from the GENUINE GIANT tree, and can be depended on to produce the GENU INE GIANT NUTS, while the imported grafted Japan Giants are such as are generally offered, and to distinguish them we have styled ours JAPAN GIANT, "Parrys'," the 'largest nuts known.

Our Pedigree Mammoth Japan Chestnuts are grown from selected seed of the genuino "Parrys" Japan Giant, and also produce nuts of immense size, which should not be confounded with what are generally offered as Japan Chestnuts; therefore, for the best results, be careful to order JAPAN GIANT, "PARRYs'," or PEDigReE JAPAN MAMmoth, if the latter are wanted.

\section{SPECIMEN NUTS (SEEDS).}

Most of these we can furnish at any season of the year, and the newer varieties of Chestnuts, not named below, in the fall. Price, except where noted, 5 cts. each, 6 for 25 cts., 40 cts. per doz., $\$ 3$ per 100 , by mail.

Chestnuts-Pedigree Japan Mammoth, Parrys' Giant, Japan; American Sweet. 3 ets, each, 10 for 25 ets., $\$ 1$ per 100 , by mail.

Walnuts - Persian (English), Madeira; Persian "Kaghazi," Japan "Cordiformis," Japan "Seiboldii." American Black. 50 ets. per doz.

Filberts. 3 cts. each, 10 for 25 cts., $\$ 1$ per 100.
Pecans-Paper Shell. 5 cts. each, 6 for 25 cts., $40 \mathrm{c}$. per doz., $\$ 3$ per 100 .

Butternuts. 5 cts. each, 6 for 25 cts., 40 ets. per doz., $\$ 3$ per 100 .

Almonds. Hard and Soft Shell. 3 ets. each, 10 for 25 ets., $\$ 1$ per 100.

Shellbark. Thin Shell. 3c. ea., 10 for 25 c., $\$ 1$ per 100 . 


\section{JAPAN CHESTNUTS.}

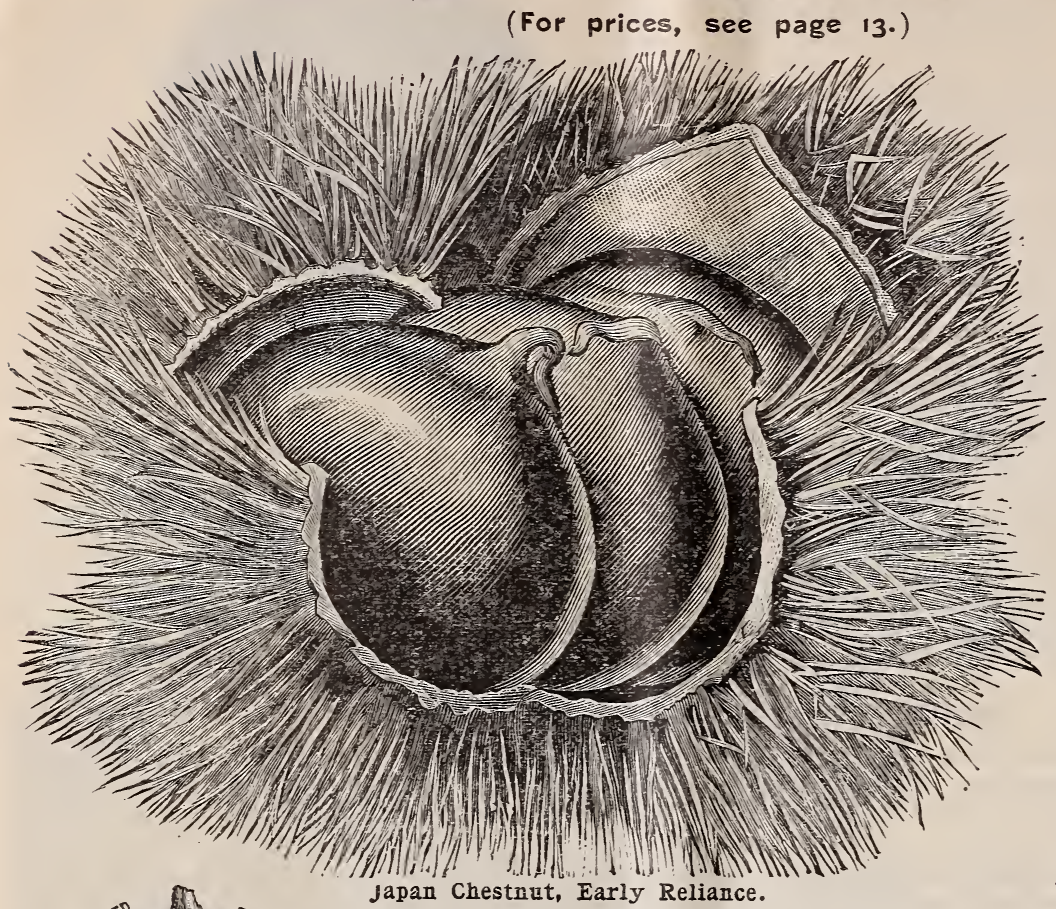

Early Relianee. Grafted. The third to ripen. Tree of low, dwarf, spreading habit, beginning to bear immediately; 1-year grafts are frequently loaded; a 10 -foot tree sometimes yields 3 to 6 quarts. Nuts large, measuring 4 inches in circumference, and running 3 to 5 nuts in the bur; smooth, bright, uniform, attractive. Ripens September 18 to 20 .

Parpys' Superb. Grafted. This superb variety is a magnificent grower, and an enormous bearer. The burs are literally packed one upon another along the branches, generally with 3 nuts to each bur, and it is the exception to find an imperfect or defective nut, nearly every one being very large, 2 inches across, full, plump, bright and

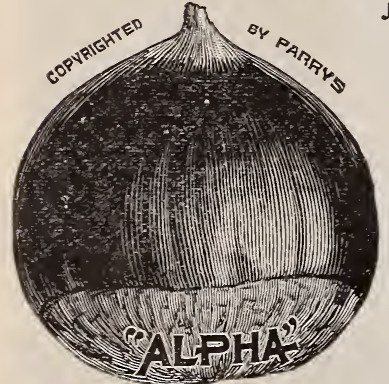

free from fuzz. Very valuable market sort. A picture of one of the burs is shown on page 16. The quality of the nuts is also very superior to that of ordinary varieties.

Alpha. Grafted. The Earliest known Chestrut. An upright, vigorous grower; comes to bearing at 2 to 3 years old and is very productive. Nuts large, 4 inches around and 2 to 3 to a bur. Ripens September 5 to 10, without frost; the earliest of all, and, therefore, always sells at unusually good prices.

Beta. Grafted. This is next to ripen. An upright, vigorous grower; comes to bearing at 2 to 3 years old, and is very productive; bears about 2 quarts to a 10 -foot tree. The nuts are large, running 2 to 3 to the bur; dark

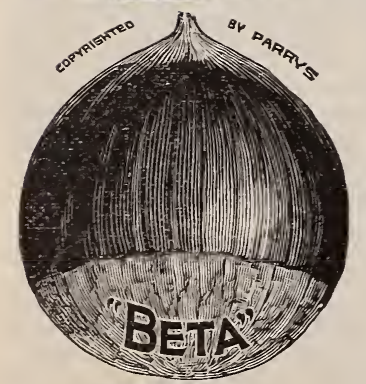
in color, smooth and handsome. Ripens September 10 to 15, closely following Alpha, and is, in turn, closely followed by Early Reliance, described above.

Parpys' Giant. Grafted. Ripens immediately after Parrys' Superb. These nuts are enormous, measuring 6 inches in circumference, and run 2 to a bur. Tree is a vigorous, upright grower and very productive; nuts smooth; dark and attractive; ripens September 25. THE LARGEST KNowN Chestrut. The picture below will give some idea of its size, as compared with that of other Chestnuts.

Success. Grafted. Tree an upright, vigorous grower, very productive. Nuts of uniformly large size; ripens September 20 to 23. Their

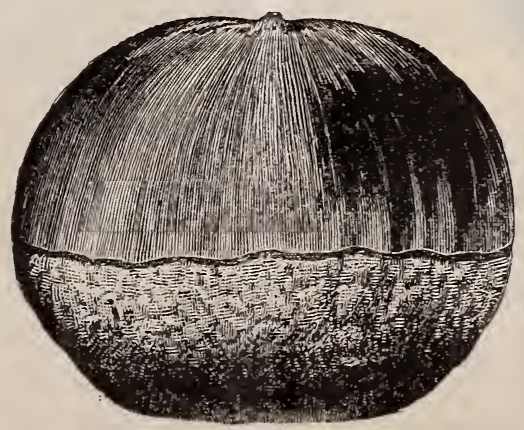
flavor is sweet and excellent.

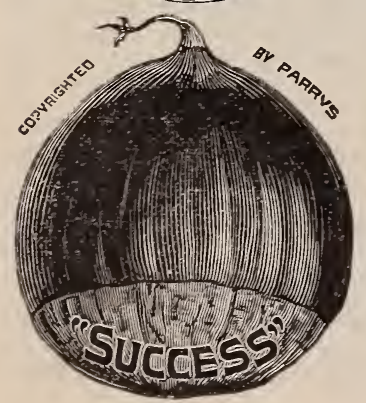

Parrys' Giant.

\section{CHINQUAPIN.}

A dwarf-growing tree of the Chestnut family, attaining a height of 8 to 10 feet, and produeing a small nut, in shape like an acorn. The tree comes to bearing very young and is enormously productive. The nuts? ripen earlier, and in delicious quality exceed the Chestnut.

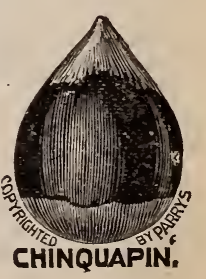




\section{SPANISH CHESTNUTS.}

These form handsome, round-headed trees of rapid, spreading growth, that yield abundantly of large nuts of good quality. Desirable ornamental trees, or profitable for market.

Numbo. Grafted. Very hardy; very productive. Comes to bearing quite young. Nuts large and of good quality, ripening early, usually before frost, and selling at high prices. (See eut, page 17.)

Paragon. Grafted. Tree hardy, productive; nuts large and of excellent quality. Two trees 4 years grafted produced one bushel of nuts each, which sold at wholesale at $\$ 10$ per bushel.

Seott. Grafted. Tree very hardy, strong grower, enormously productive, attaining large size. The original tree measures 5 feet in diameter and produces annually 3 to 5 bushels of large, handsome nuts of excellent quality, that have sold in New York market at $\$ 16$ to $\$ 18$ per bushel. The Scott trees are very precocious, producing heavy crops at 2 years from graft. Another very important feature is its almost entire exemption from attacks of the Chestnut weevil. The original tree

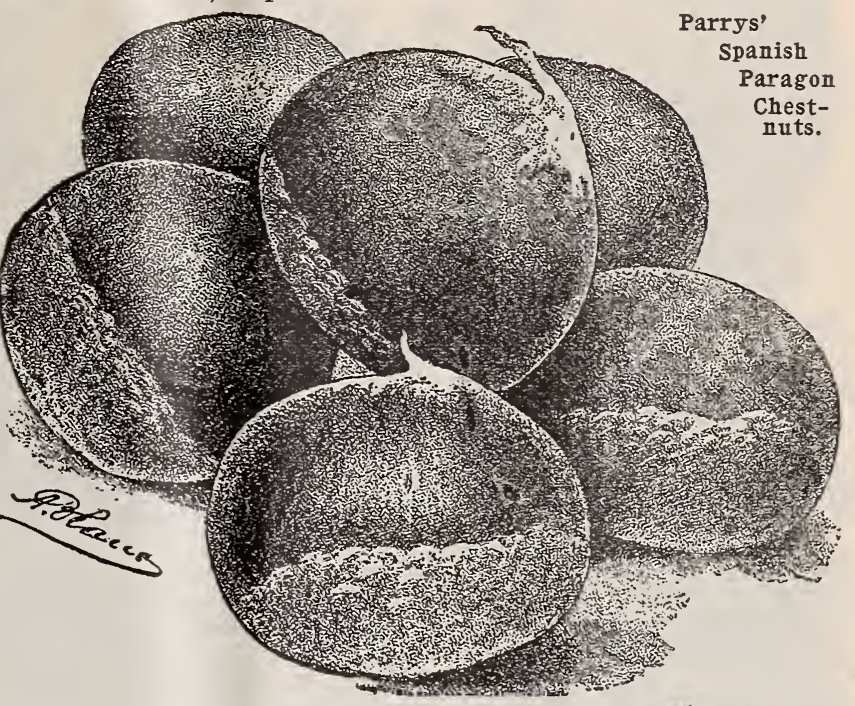

stands between two others planted at the same time, both of which have always suffered severely from the Chestnut weevil, while IT IS THE EXCEPTION TO FIND AN IMPERHECT NUT ON THE SCOTT. Young orehards propagated from the Seott so far appear to be free from worms. The nuts are large, beautiful, glossy mahogany eolor, free from fuzz, and of good quality, ripening

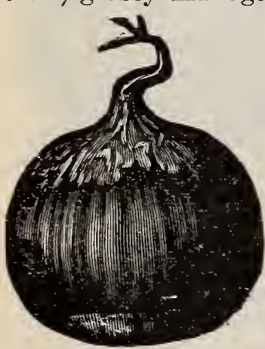

Native American Sweet.

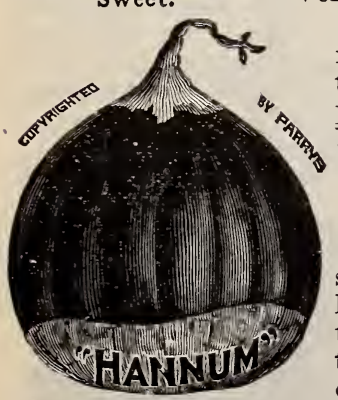
midseason. OFFERED NOW FOR THE FIRST TIME, AND THE STOCK OF TREES IS VERY LIMITED.

Comfort. A very large, handsome nut, which has been grown in Pennsylvania for many years; so nearly identical with Paragon in growth and in fruit that it is not improbable that it was from a nut of this variety that Mr. Schaeffer, of Germantown, grew the original Paragon tree. Comes to fruitage very young; is an enormous bearer; the nuts are of very good quality.

Ridgeley. Grafted. A large variety of the Chestnut from Delaware. Very productive. The erop from the original tree is reported to have brought $\$ 32$. Very good quality.

Hannum. Grafted. Tree a very vigorous, upright grower, attaining great size, the original tree having a spread of about 80 feet; immensely productive. Nuts of medium size, light in color, bright, handsome, of very good quality.

\section{NATIVE SWEET.}
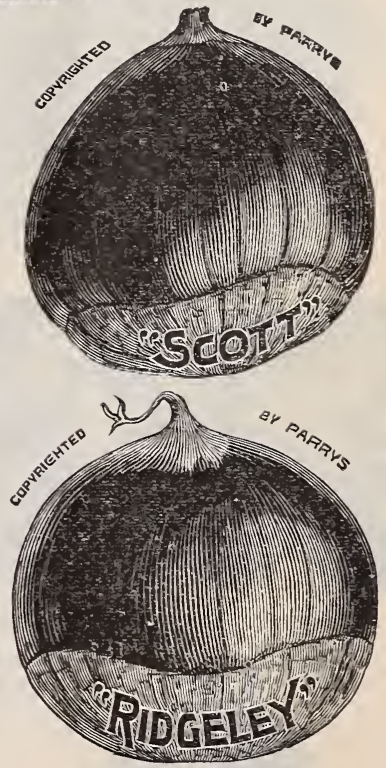

The well-known Chestnut of the forest, for sweetness and quality unsurpassed. A vigorous, healthy growing tree, and the best stock on which to graft the improved varieties. It makes a beautiful shade tree, also, showing billowy masses of creamy bloom in summer.

\section{" "NU VALUABLE PREMIUM: BY JOHN R. PARRY.... PRICE, 50 CENTS.}

AN ILLUSTRATED TREATISE on the propagation and cultivation of nut-bearing trees adapted to profitable culture in the United States, with descriptions of best varieties, and results of experience given by successful growers from various sections. Contains 157 pages, and 60 illustrations carefully engraved from nature, giving correct representations of the numerous varieties of nuts, their size, shape and general appearance, and shows the habit of growth of some of them. BUDDING AND GRAFTING receive considerable space, with cuts representing the operations in their various stages. When desired we will send A COPY BY MAIL, POSTPAID, TO ANY ONE ORDERING NUT ing the operations in their various stages. When desired we will send A COPY BY MAIL, POSTPAID, TO ANY ONE OED
TREES TO AMOONT OF \$5 WITH THE CASH; OR SEND 50 CENTS, AND THE BOOK WILL BE MAILED YOU AT ONCE. 


\section{JAPAN WALNUTS.}

(FOR PRICES on Walnuts and all other Nuts, see page 13.)

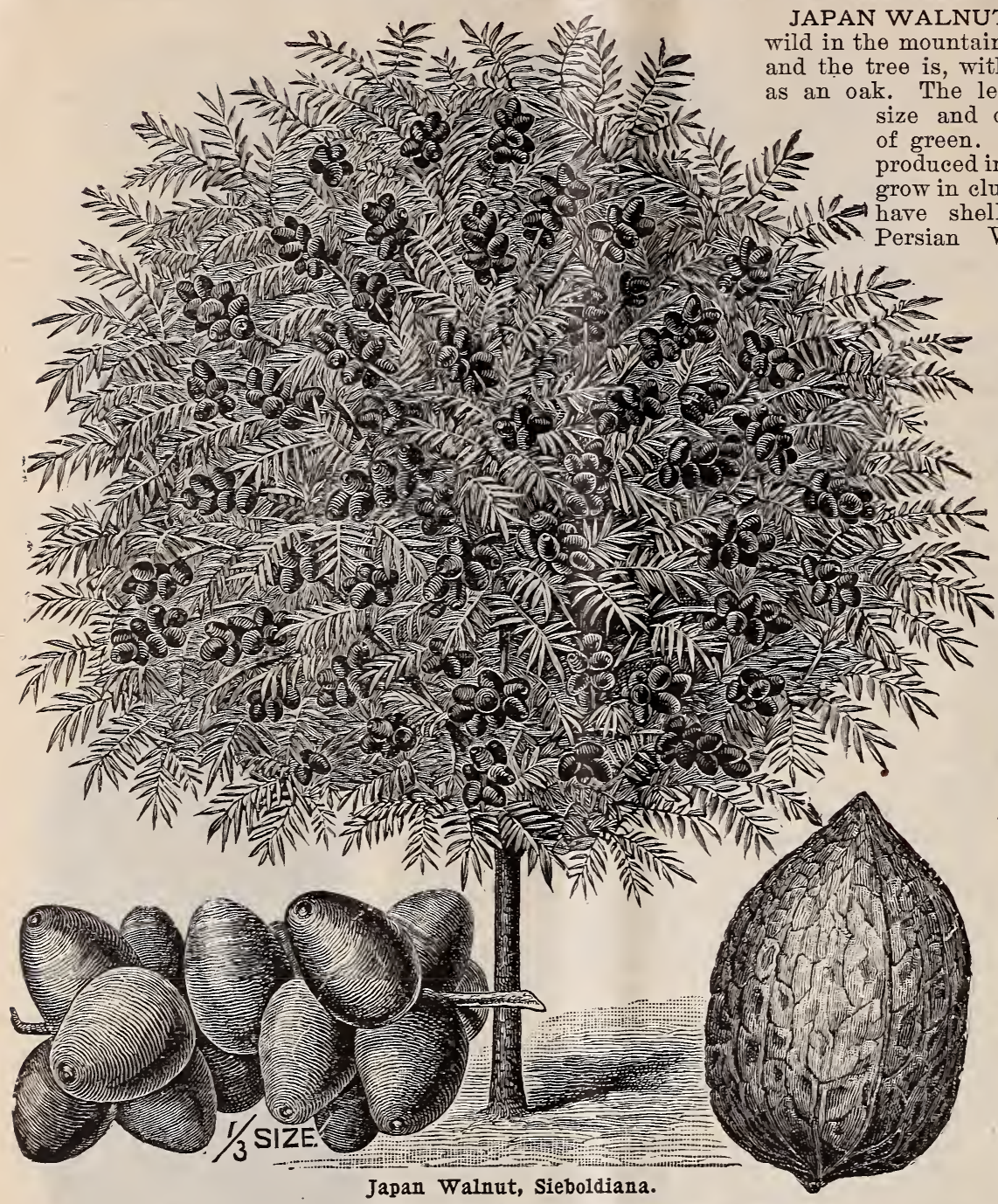

JAPAN WALNUTS are found growing in the mountains of northern Japan, and the tree is, without doubt, as hardy The nuts, which are produced in extreme abundance, grow in clusters of 15 or 20 , and Walnut thick as the black Walnut. The meat is sweet, of the very best quality, with flavor like that of the butternut, but less oily and much superior. The trees grow with great vigor, assuming a very handsome form, need no pruning; mature early, bear young, and are more regularly productive than the Persian Walnut. Having an abundance of fibrous roots, the Japanese Walnut transplants as safely as an apple tree.

Sieboldiana was probably the first Japan Walnut introduced in this country. The eut gives an excellent representation of the tree, showing habit of growth and fruiting. The cluster of nuts gives an idea of the tree's enormous productiveness, while the single specimen shows the size and shape of the nuts, which are excellent.

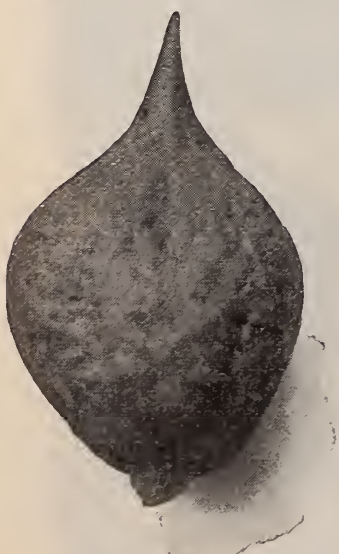

The Cordiformis Japan Walnut is rery similar to Sieboldiana in growth of tree and manner of fruiting, but has nuts more pointed and heart-shaped. The kernels are full, plump, and more easily cracked than any other known
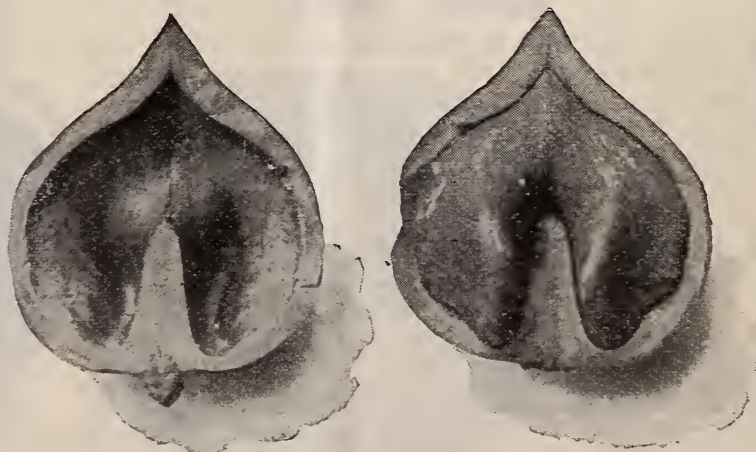
variety. By boiling the nuts for about five minutes and eracking by a slight tap while still hot, the thin shells part readily, and the fat kernel can be extracted whole, as shown in cut. This feature should render them very valuable. All who appreciate fine nuts should plant a few trees of Cordiformis, and thereby secure Japan Cordiformis walnut.-The two smaller pictures show how easily the nut may beracked not only nuts but in halves and the kernel taken out whole. 


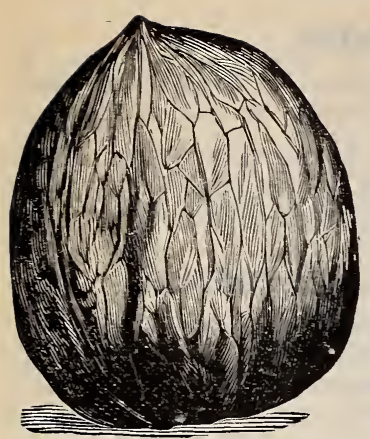

Mayette.

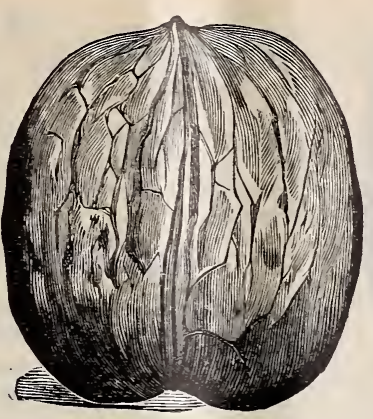

Franchette.

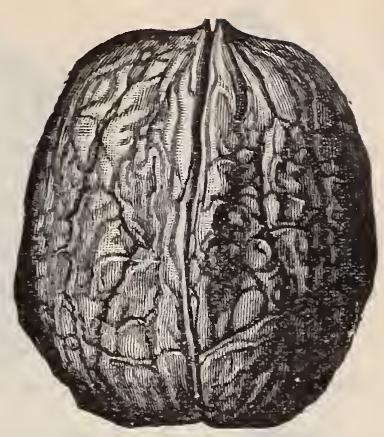

Madeira.

\section{PERSIAN WALNUTS.}

There is no reason why these delicious nuts, so largely used for dessert purposes, should not be grown in our country instead of being imported. Trees of the most popular varieties here offered have thriven and produced well in a number of different sections of our country.

Kaghazi is claimed to be the hardiest of all soft-shelled Walnuts, and stands several degrees below zero without injury. It is a vigorous, free grower and transplants readily; very prolific, producing nuts in clusters, and comes to fruiting very young. It puts out leaves and blossoms late in spring, and is therefore especially desirable for sections subject to

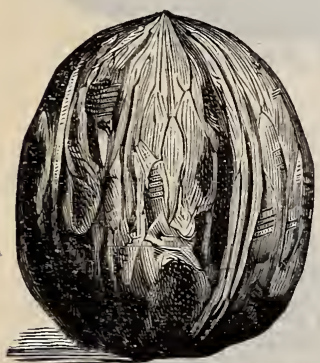

Chaberte. late frosts. The nut is larger than in the ordinary varieties; the kernel full, plump, meaty, sweeter, richer in oils and of finer flavor. The shell is thin but not tender, like some "paper shell" varieties; does not crack in handling, still may be crushed in the fingers. Very desirable and valuable.

Chaberte. Very productive, of extra fine quality; valuable.

Praeparturiens. This is of the appearance and character of the common Persian or Madeira nut, though of dwarf habit, and has the advantage of coming to bearing very young. Very hardy and productive.

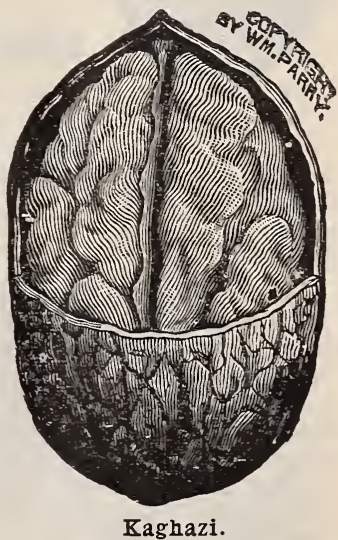

Franchette. Nuts exceeding large, elongated; of fine quality.

Mayette. This is one of the finest dessert nuts grown; large and sweet. The tree is late in budding out, hence escapes late frosts.

Madeira. A handsome-growing tree, with large, thin-shelled, delicious nuts. Also known as English Walnut.

\section{AMERICAN WALNUTS.}

The WALNUT is not only valuable as a timber tree but the nuts find a ready sale, rendering their planting a profitable investment.

American Blaek Walnut. The common Black Walnut, the wood of which is so valuable, while the nuts are always desirable.

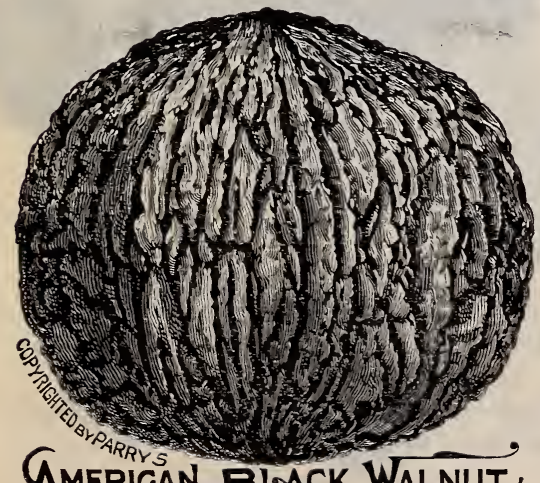

\section{BUTTERNUT.}

Tree of rapid growth, with large, luxuriant, tropical-looking foliage; very ornamental, very productive; bears young. The nuts differ from American black walnuts in being longer, with kernels of sweeter and more delicate flavor.

\section{RHUBARB ROOTS.}

Victoria and Linnæus. $\$ 1$ per doz. $\$ 1$ per $100, \$ 25$ per $\$ 1,000$.

\section{HORSE-RADISH SETS.}

Mail or express. Strong roots, that will grow off nicely. 20 cts. per doz., 50 cts. per $100, \$ 3$ per 1,000 .

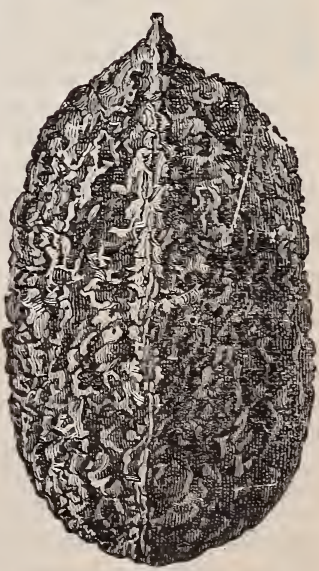

Butternut. 


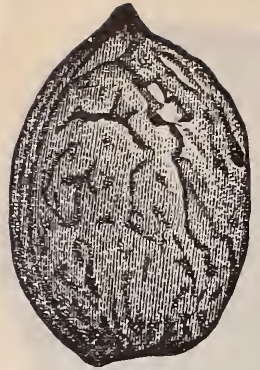

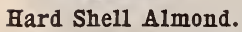

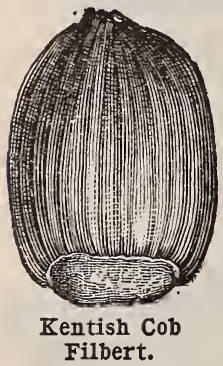

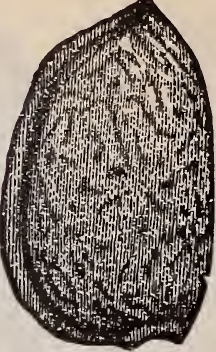

Soft Shell Almond.

\section{ALMONDS.}

Hard Shell. A fine, hardy variety. The nuts have large, plump kernels, and the tree large, showy, ornamental blossoms.

Soft, or Paper Shell. This is what is known as the "Ladies' Almond, or Lady Finger of the Shops." Although preferable to the HARD SHELL, it is not so hardy; kernel sweet and rich.

\section{FILBERT HAZELNUTS.}

These are of the easiest culture, and among the most profitable and satisfactory nuts to grow. The bushes are of dwarf habit, entirely hardy, abundant yielders; succeed almost everywhere, and come into bearing young.

English. The sort usually sold at the fruit stands.

Kentish Cob. This is one of the finest and largest of Filberts; oblong, of excellent quality.

Cosford Thin Shell. An English variety; valuable for thinness of shell and sweetness of kernel.

\section{PAPER SHELL PECANS.}

A beautiful, symmetrical, rapid-growing tree, of luxuriant foliage, which it retains late in the fall. Produces valuable timber and heavy crops of sweet, oblong, smooth nuts of very good quality.

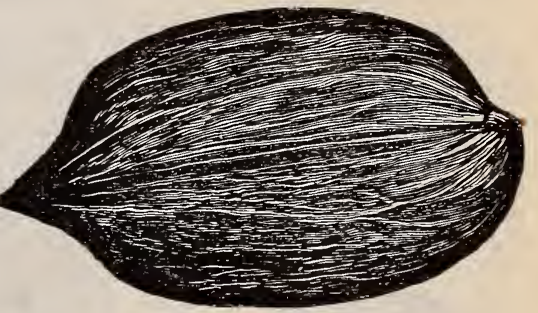

Pecan.

\section{ELAEAGNUS LONGIPES.}

A valuable new fruit, and a magnificent ornamental shrub from Japan. Perfectly hardy; free from diseases of all kinds. Very attractive when in bloom in May, after which until late in fall it is clothed in luxuriant green foliage, silvery underneath, and producing in profusion handsome bright red cherries, which make delicious sauce.

Wy. FALCONER said in The Rural New-Yorker: "The shrub Eleagnus Longipes is one of my special favorites. I have grown it for years, and the longer I know it the better I like it. It is a native of Japan, belongs to the olive family of plants, and is perfectly hardy. As a garden shrub it grows to a height of 5 feet or more, is bushy, broad and thrifty; plants begin to fruit when 2 or 3 years old. The flowers are small, silvery yellow, borne in great abundance, and in full bloom about May 6 to 10 . The fruit is oval, $5 / 8$ of an inch or more long, very fleshy and juicy, bright red, and drooping on slender pedicels on the underside of the twigs, and borne in immense profusion. It is ripe about July 4 to 10 . We use the fruit for sauce as one would eranberries, and a delicious sauce it makes, especially for children; indeed, I like it so well that I have planted it in our fruit garden as a standard crop the same as currants." Price, 2-year trees, mail or express, 15 ets. each, $\$ 1.50$ per doz., $\$ 7.50$ per 100 ; 3 -year, by express, 25 cts. each, $\$ 2.50$ per doz., $\$ 10$ per 100 .

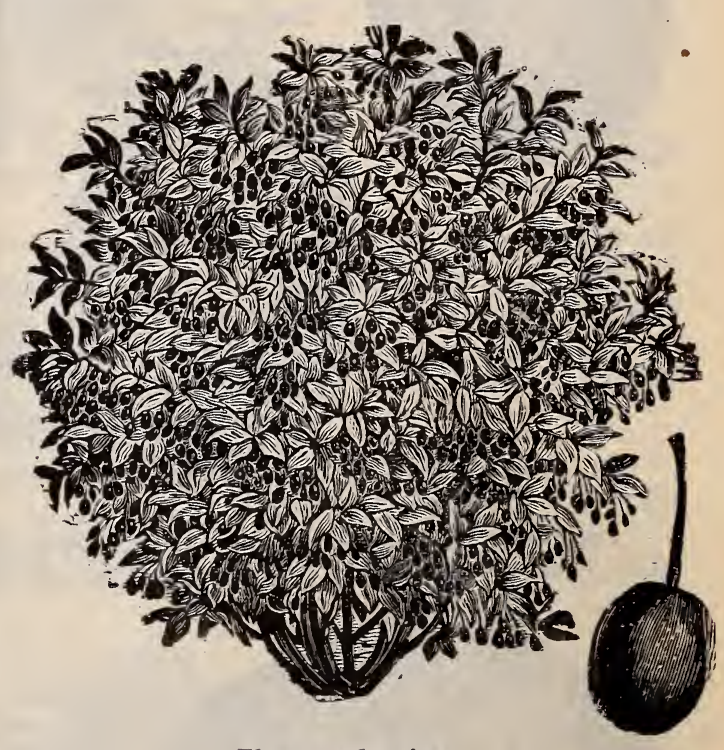

Elæagnus longipes.

\section{TREES AND PLANTS BY MAIL.}

THRIfTY, WELL-ROOTED TREes AND PLANTS OF MEDIUM sIze receive less shock in transplanting, suffer less in transportation, start off more promptly, make better growth and better trees, and are in many ways more desirable than larger stock.

In order to supply our patrons who are remote from express office, and where express rates are high, we will furnish such trees and plants at prices stated by mail, postpaid to any post office in the United States, however distant. Safe arrival guaranteed. 


\section{Cuttings or Cions for Rooting, Grafting or Budding}

PEARS, 12 inches. General List . . . . . .

$\overbrace{\text { Each }}$ Mail- $-\sim$ Express $-\frac{}{100}$

APPLES, 12 inches. General List . . . . . .

$\begin{array}{lllllll}\$ 0 & 05 & \$ 0 & 25 & \$ 0 & 75 & \$ 500\end{array}$

Starr, Parlin and Bismarck . . . . .

QUINCES, 7 to 8 inches. Heech and Champion

$\begin{array}{lllll}05 & 25 & 75 & 5 & 00\end{array}$

PEACHES, 12 inches. General List .... .

10

.05

PLUMS, 12 inches. General List

50

$50 \quad 100 \quad 500$

05

Juicy, Milton and Wickson

$0 \overline{5}$

$\begin{array}{lllll}50 & 1 & 00 & 5 & 00\end{array}$

$\begin{array}{llllll}50 & 1 & 00 & \tau & 50\end{array}$

CHERRIES, 12 inches. General List . . . . . . . .

CHESTNUTS, 12 inches. Pedigree Japan Mammoth . . . . . . . . 10

Alpha and Parrys' Superb, 12 inches . .

Advance, Reliance, Suceess, Hannum and Scott . . . . . . . . . 15

Parrys' Giant

Numbo, Paragon, Comfort and Ridgeley

PECANS, CHINQUAPINS and ENGLISH WALNUTS .

ALMONDS, 12 inches. Hard and Soft Shell .

$7 \tilde{5} \quad 150$

$\begin{array}{llllll}50 & 1 & 00 & 10 & 00\end{array}$

$\begin{array}{llllll}50 & 1 & 00 & 10 & 00\end{array}$

$\begin{array}{lllllll}150 & 12 & 00 & 100 & 00\end{array}$

$\begin{array}{lllllll}1 & 50 & 12 & 00 & 100 & 00\end{array}$

$\begin{array}{lllrrr}1 & 00 & 5 & 00 & 40 & 00\end{array}$

$\begin{array}{lllllll}1 & 50 & 3 & 00 & 30 & 00\end{array}$

MULBERRIES. Downing and New American

150

$100 \quad 250$

$75 \quad 250$

2000

Special quotations for large quantities.

\section{Small Fruits.}

\section{GOOSEBERRIES.}

GooseberRY PLANTS will be sent by mail, postpaid, at dozen rates, and by mail at 100 rates, for $25 \mathrm{c}$. additional for 50 plants and $50 \mathrm{c}$. additional for 100 plants.

Pearl. A very productive and perfectly healthy variety, quite free from mildew. Pearl is a favorite, and hard to beat; bushes planted but one year are said to yield three quarts of berries. A robust, vigorous grower, with berries larger than Downing, and of excellent quality.

Columbus. A new yellow variety; very prolific, free from mildew ; fruit larger than Industry.

Triumph. An American seedling of the English type. Fruit large, golden yellow; bush hardy, an immense bearer. Tery promising.

Chautauqua. "A new white Gooseberry, equaling the finest and largest varieties in size, beauty and quality, and excelling them all in vigor and yield."

Red Jacket. Claimed to be the best red Gooseberry in existence. Foliage mildew-proof; fruit

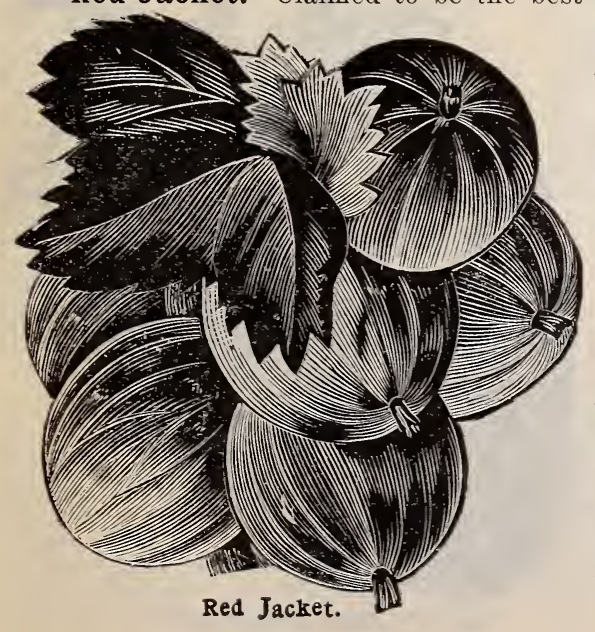
of the best quality; as large as the largest; berry smooth. Tery prolific and hardy; a splendid cropper, with exceptionally clean, healthy foliage. Will succed under circumstances where the common sorts fail.

PRICES OF GOOSEBERRIES.

\begin{tabular}{|c|c|c|c|}
\hline & & ail. & Exp. \\
\hline \{1-year.. & $\begin{array}{r}\text { Each } \\
. \$ 030\end{array}$ & $\begin{array}{c}\text { Per doz. } \\
\$ 250\end{array}$ & $\begin{array}{c}100 \\
\$ 2000\end{array}$ \\
\hline UTAUQUA, $\left\{\begin{array}{l}2 \text {-year... } \\
\text {-year }\end{array}\right.$ & 50 & 500 & \\
\hline OLUMBUS . & 25 & $2 \tilde{5} 0$ & \\
\hline 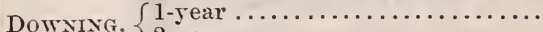 & 10 & 75 & \\
\hline 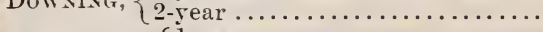 & 10 & 100 & \\
\hline$\{1-$ year.................... & 10 & 50 & 200 \\
\hline$\ldots \ldots \ldots \ldots \ldots \ldots \ldots$ & 10 & 75 & \\
\hline 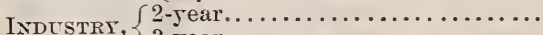 & 10 & 100 & 6 \\
\hline 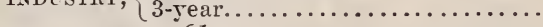 & 15 & 150 & \\
\hline n......... & 10 & 100 & \\
\hline ACKE & 20 & 200 & \\
\hline מ & 10 & & \\
\hline & 10 & & \\
\hline$\ldots$. & 20 & 250 & \\
\hline & & & \\
\hline
\end{tabular}

special quotations for large quantities. 


\section{CRUNELLS.}

Claimed to be a cross between the gooseberry and the currant; FREE FROM MILDEW, RUST, WORMS and THORxs. Plant an upright, healthy, clean, vigorous grower, resembling Crandall currant in foliage and

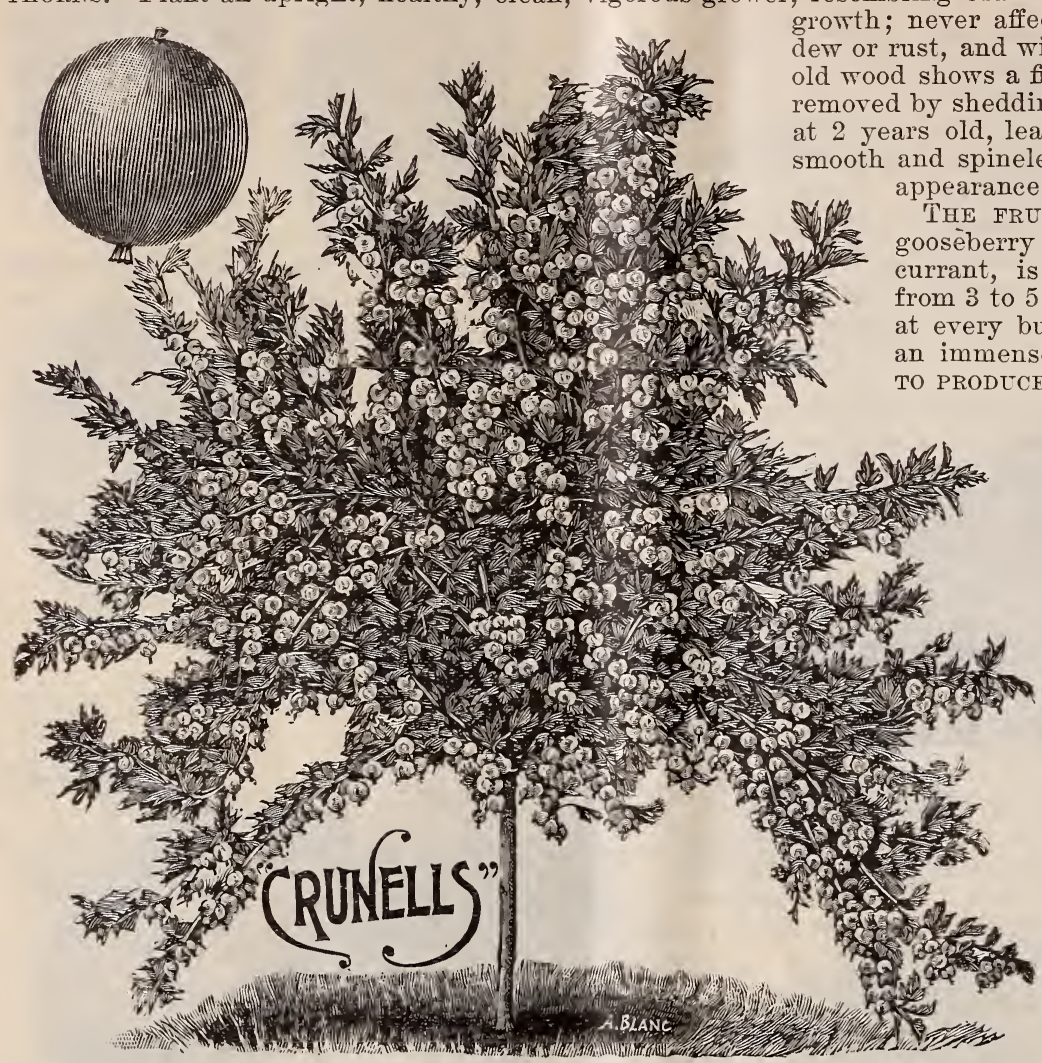
growth; never affected in the least by milshows a fine, hairy spine, which is at 2 years old, leaving the canes perfectly appearance of a currant bush.

THE FRUIT, which resembles the more than the to 5 and 10 berries each, and mense weight of fruit. SAID 5 TIMES AS MUCH FRUIT GOOSEBERRY OR CURRANT, and has averaged 9 cents per quart for the last 10 years. The fruit is good to eat out of hand when ripe, having a peculiar, pleasant flavor of its own, distinct from either the gooseberry or currant; served as jelly, jam, or in pies it is delicious. Price, mail or express, 1-year, 25 cts. each, $\$ 2.50$ per doz.; 2-year, 50 cts. each, $\$ 5$ per doz.

\section{CURRANTS.}

Currant Plants will be sent by mail, postpaid, at dozen rates, and by mail at 100 rates for $25 \mathrm{c}$. additional for 50 plants and $50 \mathrm{c}$. additional for 100 plants.

Cherry and La Versailles. Large, red. 1-year, by mail, 50 cts. per doz.; by express, $\$ 2$ per $100, \$ 20$ per 1,$000 ; 2$-sear, by mail, 75 cts. per doz.; by expres, $\$ 2.50$ per $100, \$ 20$ per 1,000 .

White Grape. White, handsome, good. 1-year, by mail, 50 cts. per doz.; by express, $\$ 2$ per $100, \$ 20$ per 1,000 ; 2-year, by mail, 75 cts. per doz.; by express, $\$ 2.50$ per $100, \$ 20$ per 1,000 .

Red Dutch. Very prolific. 1-year, by mail, $50 \mathrm{cts}$. per doz.; by express, $\$ 2$ per 100, $\$ 20$ per 1,000; 2-year, by mail, 75 cts. per doz.; by express, $\$ 2.50$ per $100, \$ 20$ per 1,000 .

Black Naples. Good for jelly. 1-year, by mail, 50 cts. per. doz.; by express, $\$ 2$ per 100 , $\$ 20$ per 1,000; 2 -year, by mail, 50 cts. doz.; by express, $\$ 2.50$ per $100, \$ 25$ per $\mathbf{i}, 000$.

Fay's Prolific. Red. 1-year, by mail, $10 \mathrm{cts}$. each, 75 cts. per doz.; by express, $\$ 3$ per $100 ; 2$-year, by mail, 15 cts. each, $\$ 1.05$ per doz.; by express, $\$ 5$ per 100 .

Crandall. Black. 1-year, by mail, 20 cts. $\in a c h, ~ \$ 1.50$ per doz.; by express, $\$ 8$ per $100 ; 2$-year, by mail, 25 cts. each, $\$ 2$ per doz.; by express, $\$ 10$ per 100 .

North Star is claimed to be the hardiest, the best grower, the most prolific bearer, the sweetest and best Currant grown. 1-year, by muil, 10 ets. each, 75 cts. per doz.; by express, $\$ 5$ per 100; 2-year, by mail, 15 cts. each, $\$ 1$ per doz.; by express, $\$ 5$ per 100.

Special quotations for large quantities.

\section{STRA WBERIRIES.}

WE ENDEAVOR to handle our plants in the very best manner. They are carefully cleaned, the roots straightened and neatly tied in bunches of 50 each. In filling orders we take up the beds solid, and the purchaser receives the strongest and best plants made during the season of growth. These are worth much more than plants dug from the alleys, which are the last efforts of the runners, and are apt to be small and weak.

Among the best early varieties we would name "THE Leader," Lovett's Early, Michel's Early, Bomba, Parry, Crescent, Bubach, and Vax Deman.

Midseason-Cumbertuand Triumph, Sharpless, Jessie, and MARSHALI.

Late-Kentucky, Gandy, Timbrell, and Brandywine.

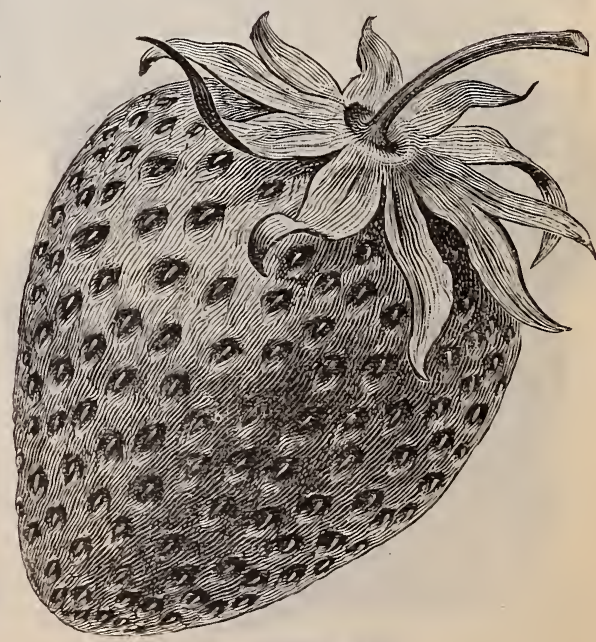

Lovett's Early Strawberry. 
STRA WBERRIES, continued.

Nick Ohmer. The plant is very large and stocky, sending out plenty of very strong runners. It is prob ably not surpassed in healthy, vigorous growth and great productiveness by any variety. It has a perfec blossom. Fruit of largest size, a giant among Strawberries; dark glossy red, firm and of excellent flavor.

Leader. An exceedingly early, very large berry of crimson color; firm, a good shipper, and of good quality A very strong staminate rariety and good grower, with clean, healthy foliage; very productive.

Greenville has proved to be one of the best among 150 varieties fruited at the Missouri Agricultural Experi ment Station. Crescent is the only Strawberry equaling it in productiveness, while but two exceeded it in size. A good grower, with no inclination to rust.

Henry Ward Beecher. (Per.) For enormous yield of large, handsome berries under all circumstances we know of no better variety. It is, indeed, an excellent sort. The berries are large, handsome, of great firmness and high quality; the plant is immensely productive. This variety has is sen subjected to the sererest tests, and has proved itself a truly wonderful berry, developing not a single defect. For market it cannot be excelled, possessing, as it does, remarkable size, productiveness, firmness and good quality. An excellent berry for canning. Season early to medium.

Brandywine. Extract from The Rural New-Yorker: "BRANDYWINE is of immense size and fine qualityquite firm and shapely for so large a berry. Foliage of the largest and thriftiest, entirely free from scald or blemish. The average size is as large as any ever raised, and the shape is more uniformly good than that of any other of the largest varieties. It is generally

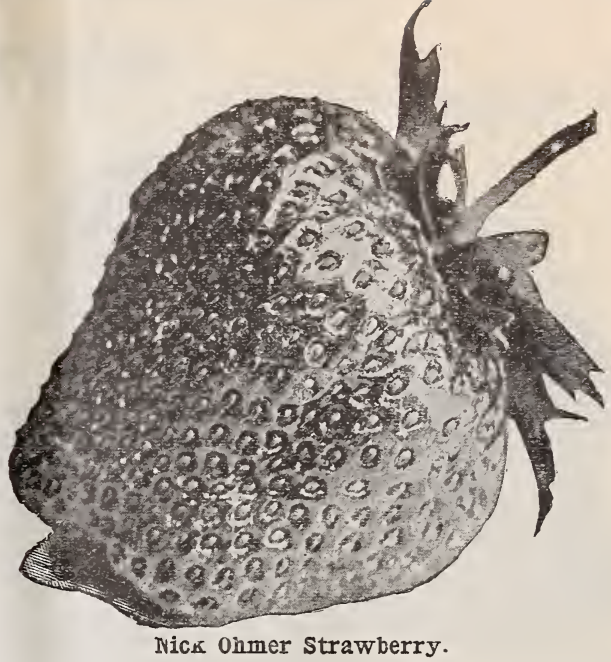

heart-shaped, medium red; flesh red, firm and solid for so large a berry-none more so; quality fully as good as Sharpless; exceedingly prolific. The best berry in our collection of this season up to date. Foliage perfect; continues a long time in fruit."

Bubach No. 5. (Imp.) Very large, has fine color; good quality, ripens early; very productive and strong grower; raluable.

\section{PRICES OF STRAWBERRY PLANTS.}

We can supply Strawberry plants during August at given rates per dozen; during September at dozen and 100 rates; in the fall, after October 15, during November, and in the spring at dozen, 100 and 1,000 rates. No plants furnished at 1,000 rates in the fall until after October 15.

THE PRICES HEREIN NAMED ARE FOR LAIER PLANTS. Then given two weeks' notice we can furnish pot-grown plants during August, September and October, at additional cost of 25 cents per doz., \$1.50 per 100 .

Strawberry plants at the dozen rates will be mailed free; at the 100 rate add 25 cents per 100 to cover postage, packing, etc. Send for special prices for large quantities of Strawberry plants.

\begin{tabular}{|c|c|c|c|c|c|c|c|}
\hline & ant & $-\mathrm{E}$ & $s$ & & & & \\
\hline Albany, Wilson (Per.) & $\begin{array}{l}\text { er doz. } \\
3025\end{array}$ & $\$ 0 \stackrel{100}{50}$ & $\begin{array}{l}1,000 \\
\$ 300\end{array}$ & Lovett (Per.) & $\begin{array}{l}\text { er doz. } \\
\$ 0 \\
25\end{array}$ & $\begin{array}{l}100 \\
\$ 0\end{array}$ & $\begin{array}{l}1000 \\
\$ 300\end{array}$ \\
\hline Beder Wood (Per.) ............... & 25 & 50 & 300 & MIargaret... & 50 & 100 & 500 \\
\hline Bomba (Per.).......... & 35 & 75 & 500 & Marshall (Per.) & 25 & 50 & 400 \\
\hline Bismarck (Per.). & 50 & 100 & 500 & Lary (Imp.)... & 25 & 50 & 400 \\
\hline Brandywine (Per.)................. & 35 & 75 & 400 & Meek's Early (Imp.) ............... & 25 & 50 & 300 \\
\hline Brunette...................... & 35 & 75 & 400 & hel Early (Per.)................ & 25 & 50 & 300 \\
\hline Bubach (Imp.)... & 35 & 50 & 40 & $\ldots \ldots \ldots, \ldots, \ldots, \ldots$ & 50 & 100 & 800 \\
\hline Canoe........... & 35 & 75 & 500 & cean City (Per.) ............. & 25 & 50 & \\
\hline Charles Downing (Per.) & 25 & 50 & 30 & . & 5 & 50 & 300 \\
\hline Clyc & $3 \tilde{5}$ & 75 & 40 & rker Earle ( $\mathrm{Pe}$ & 35 & 100 & 500 \\
\hline$(\operatorname{Imp}$ & 25 & 50 & 30 & $\ldots \ldots \ldots \ldots \ldots$ & 25 & 50 & \\
\hline ........... & 25 & 50 & 30 & hief (Per.). & 25 & 50 & 300 \\
\hline Ell & 50 & 100 & 75 & $(\operatorname{Imp}) \ldots \ldots \ldots \ldots$ & 25 & 50 & 300 \\
\hline ... & 35 & 75 & 40 & . & 50 & 100 & 500 \\
\hline$\ldots$ & 35 & 75 & 4 & & 25 & 50 & 400 \\
\hline$(\mathrm{Pe}$ & 25 & 50 & 30 & (Per.) & 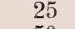 & 50 & \\
\hline & 35 & 75 & & (D) & 50 & 100 & 500 \\
\hline Gle & 40 & 100 & 5 & ( & 25 & 50 & 300 \\
\hline & 25 & 50 & 3 & & 25 & & 300 \\
\hline $\mathrm{Ha}$ & 25 & 50 & 30 & (Per.)... & 25 & 50 & 300 \\
\hline Ward Beecher (Per.). & 23 & 50 & 30 & & 25 & 50 & \\
\hline .... & 3 & 75 & 50 & $\mathrm{~T}$ & 35 & 100 & 400 \\
\hline (Per) & 25 & 50 & 30 & & & 50 & \\
\hline & 2 & 50 & 3 & X & & & 300 \\
\hline & 2 & 50 & 3 & & & 50 & \\
\hline & 2 & 50 & 3 & (Imp.) & 25 & 50 & 300 \\
\hline Leader (Per.) & & 50 & & ial quotations & & & ties. \\
\hline
\end{tabular}

\section{RUBUS SORBIFOLIUS.}

\section{(Strawberry-Raspberry.)}

A Japan variety of the raspberry or blackberry family but little known in this country. It is of robust, upright, spreading habit, similar to the raspberry, except that it dies to the ground every fall and the fruit is produced on the young growth made the next year, by which we should think it would be well adapted to cold climates. Fruit large, red, handsome, luscious, resembling in size and form the strawberry; of sprightly subacid, pleasant flavor; excellent for sauce, jams, or as a dessert fruit; ripens with the raspberry. That this novelty may be thoroughly tested, we offer plants at the moderate price of 10 ets. each, 50 cts. per doz., $\$ 2$ per 100 , $\$ 12$ per 1,000 . 


\section{RASPBERRIES.}

RASPBERRY PLANTS will be sent by mail, postpaid, at dozen rates, and by mail at 100 rates, for 25 cts. additional for 50 plants, and 50 cts. additional for 100 plants.

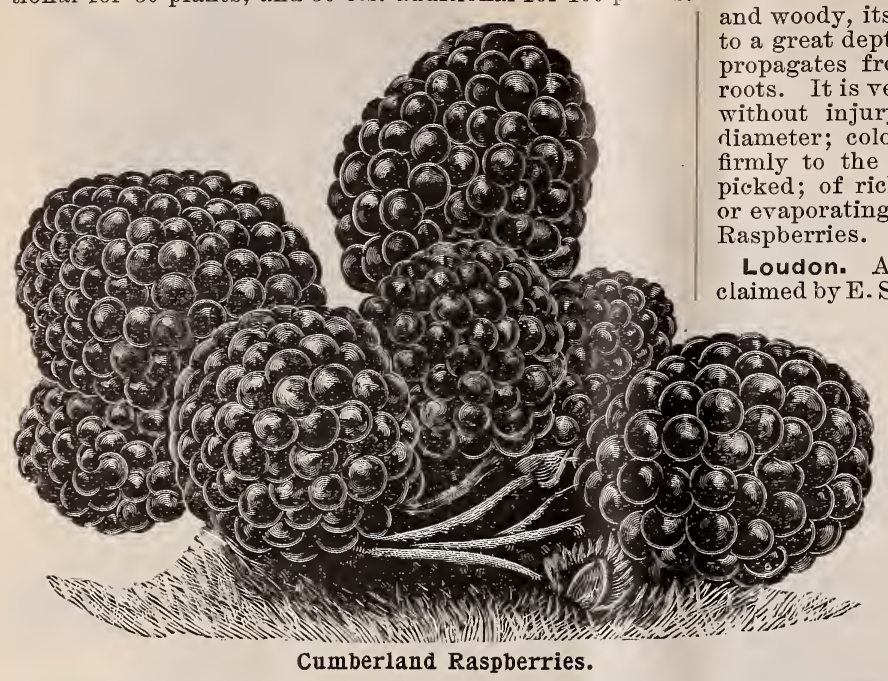

and woody, its roots spreading and penetrating the soil a great depth, thus enabling it to resist drought. It propagates from the tips and never suckers from the hardy, enduring 28 degrees below zero injury. Fruit very large, often an inch in ter; color dark red, bordering on purple; adheres ; of rich, sprightly flavor; the best for canning the most productive of all aspberries.

Loudon. A new Red Raspberry from Wisconsin; . CARMAN, of The Rural New-Yorker, and others, to be THE BEST RED RASPBERRY IN ExIstence. Plants hardier and more vigorous even than Cuthbert; canes virtually thornless. Begins to ripen with Cuthbert and continues longer; berries are larger, firmer and of brighter color; they cling well to the stem and never crumble. Will remain on bushes longer after ripe than any other berry, is the best of shippers, and will stand up longer in market than Cuthbert; enormously productive and of excellent quality.

Munger. Strong grower, very hardy and productive; fruit very large, an inch in diameter, 5 to 8 days later than

Cumberland. (Blackcap.) Claimed to be the largest Raspberry known. Selected specimens measure an inch in diameter, while they are uniformly very large. The canes are extremely hardy, having undergone a temperature of 16 degrees below zero unprotected without injury. They are immensely productive, producing annually very heavy crops. Fruit firm, and in quality equal to the very best blackcaps ; very black, showing little if any of the bloom so objectionable to some; season a little in advance of Gregg.

Phoenix. Of ironclad hardiness; a vigorous, upright grower, with stout, sturdy canes; immensely productive. Fruit of large size, bright red; equal to the old Hudson River Antwerp in high quality, lusciousness and superior shipping properties.

Columbian. A most vigorous grower; canes 10 to 15 feet long and often over an inch in diameter; strong
Gregg, which it much resembles.

Miller Red has been grown and fruited largely for the past 10 years, and is no untried novelty. The bush is a stout, healthy, vigorous grower, not quite so tall as Cuthbert, rather more stocky and dwarf, and is well calculated to hold up the immense crops of large, luscious berries with which it is loaded. It is very hardy, remaining unhurt when Cuthbert and Thompson, in same field, were badly winter-killed. Berry is large as Cuthbert, holding its size until the end of the season; is round, bright red, does not fade, but will hold its color after shipment longer than any other red variety; the core is very small, the berry does not crumble and is the finest and best shipping berry in existence ; of rich flavor and very good quality. Time of ripening is with the earliest and continued until the end of the Raspberry season. Special prices for large quantities of Miller Red.

\section{PRICES OF RASPBERRIES.}

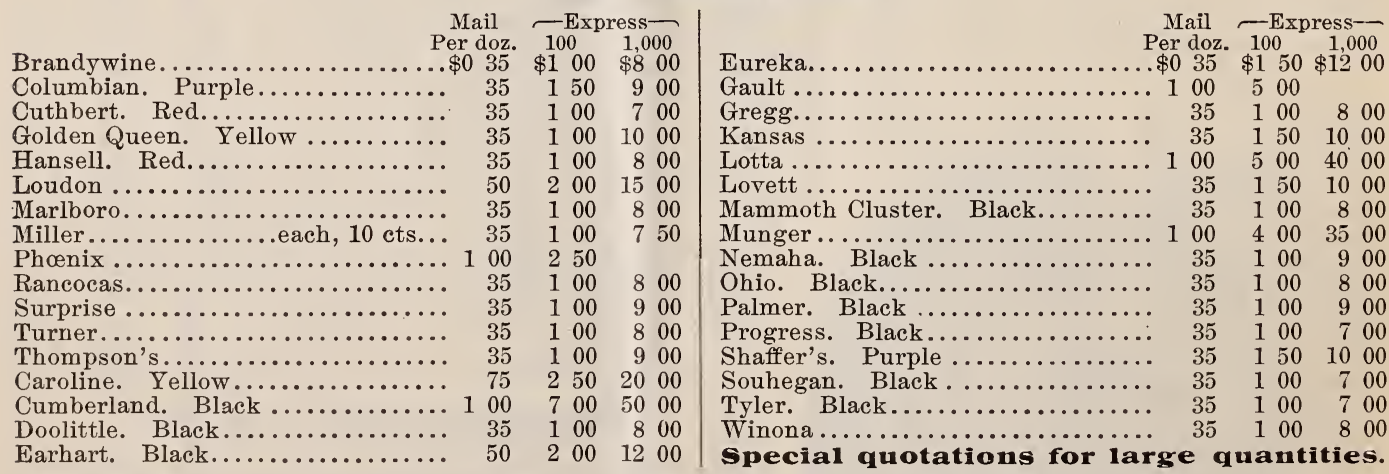

\section{THE JAPANESE WINEBERRY.}

THE CANES of this interesting plant are large, robust and entirely hardy here; they are thickly covered with purplish red hairs, which extend along the stem to the extremity. Each berry is at first tightly enveloped by the large calyx, forming a sort of bur, which is also covered with purplish red hairs so thickly as to present the appearance of a moss rosebud. These gradually open and turn back, exposing the fruit in all its beauty.

ThE BERRIES are of medium size as compared with our raspberries, but are of a beautiful, translucent appearance, running through all the shades of amber to crimson as they ripen. There is a freshness and briliancy about them impossible to describe, and we know of nothing in the way of raspberries so attractive.

IN QUALITY the fruit is good, with a rich and sprightly flavor, but decidedly brisk subacid. When cooked it is simply grand, surpassing by far when canned the huckleberry and all other small fruits. Season of ripening early July. Price, mail or express, $10 \mathrm{cts}$. each, $50 \mathrm{cts}$. per doz., $\$ 1.50$ per 100, $\$ 10$ per 1000. 


\section{BLACKBERRIES.}

BLACKRERRY PLANTS will be sent by mail, postpaid, at dozen rates, and by mail at 100 rates, for 25 cents additional for 50 plants and 50 cents additional for 100 plants.

New White Blackberry, "ICEBERG." Mr. Burbank says of this berry: "Owing to the somewhat unsatisfactory qualities of White Blackberries so far known, the impression may have been entertained by some that no White Blackberry could be as productive and hardy, with berries as early, abundant, large, handsome and delicious, as the best black ones.

"THE WELL-KNOWN LAWTON Is, when ripened, unsurpassed, and very generally known as the most productive market berry. Owing to its fixity of race, it will reproduce itself from seed almost exactly, and its seedlings will not be influenced when raised from seed pollenated by other varieties, but it really imparts its good qualities when employed as the staminate parent. One of the great grandparents of 'Iceberg' was Lawton. The first generation of seedlings, when crossed with Crystal White, were all black; the second also, though varying much in other respects; but the third produced this wonderful plant, bearing the snowiest white berries ever seen. Very little attention was paid to the long rows of cross-bred descendants, until one day this berry was discorered among its black relatires, with the canes bending in various directions with their load of DELICIOUS, SNOWY BERRIES, which are not only white, but so TRANSPARENT THAT THE SEEDS, WHICH ARE UNUSUALLY SMALL, MAP BE SEEN IN THE BERRIES WHEN RIPE.

"Clusters larger than those of Lawton; berries, as near as could be judged, were at least as large, earlier, sweeter, and more tender and melting throughout, though as firm as Lawton is when ripe."

Lovett's Best. A thoroughly reliable Blackberry of large size, with canes of ironclad hardiness. Lovett's Best unites not only these two invaluable properties in an eminent degree, but possesses in addition the merits of ripening early, great productiveness, entire freedom from disease and double or rose blossom, vigorous growth of cane, extra high quality, jet black permanent color and fine appearance. Either for profitable market growing or for the home garden, it is without an equal. It has now been fruited in almost erery state in the Union, and its hardiness and other valuable properties have been conclusively proved by practical field tests.

Eldorado is described as a very vigorous grower, free from mildew, rust or double blossom, enormously productive, even hardier than Snyder; fruit large to very large, excellent quality, free from core. This berry originated in Ohio, and has been tested at many of the experiment stations, and in Canada. It has been exposed to very low temperature, and has never been winterkilled in the least, always producing an immense crop of the most delicious fruit, which ripens with the early varieties.

Minnewaski. Canes hardy, very productive, stronggrowing, free from disease; fruit large, early, of good quality.

Erie. As hardy as Snyder, as vigorous as Kittatinny; very productive; free from rust or double blossom fruit of good quality, round, as large as Lawton.

Maxwell Early. It would be difficult to overestimate the value of a Blackberry as large as or larger than Wilson's Early and ripening as early as Early Harvest, yet this is claimed for Maxwell Early. Very large, sweet, rich, luscious, melting, with no core whatever; ripens before strawberries are gone, or at same time with Lucretia Dewberry and Early Harvest Blackberry, and

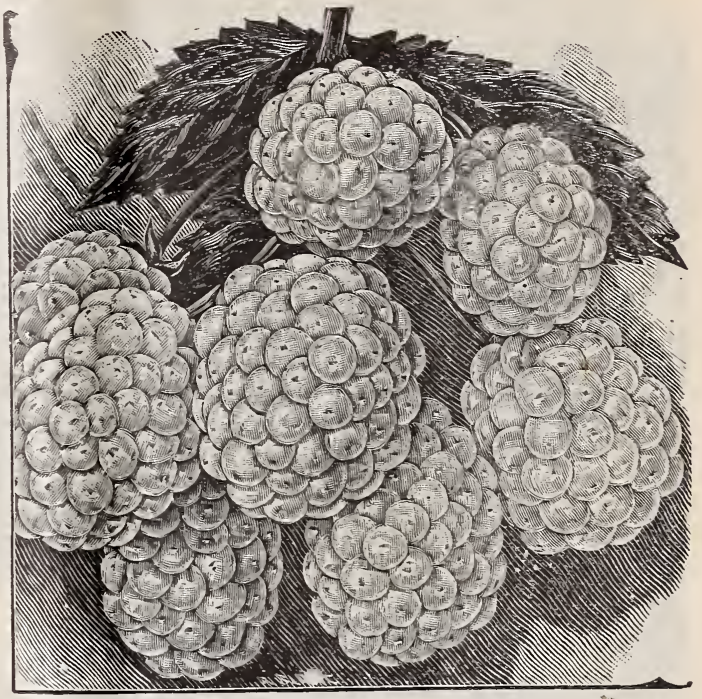

New White Blackberry, "ICEBERG."

is three times as large as the latter. Bush a low, strong, stocky grower, free from rust, double blossom or other disease; very productive.

Ohmer. Canes hardy, healthful; fruit very large, ripening after raspberries are gone and lasting until late in August, when prices are up; of excellent quality, firm, with no core, and sweet before soft or fully ripe.

Lucretia Dewberry. Claimed to be the best of the Blackberry family. As hardy as Snyder; as productire as any. The berries are far larger and incomparably better than any Blackberry-soft, sweet and lu scious throughout; of brightest glossy black color. The Lucretia Dewberry has received endorsement and highest praise from the best horticulturists in the country. Its eminent success in all soils, from Maine to California, from Minnesota to Florida, is something phenomenal in mall fruit culture.

Austin's Dewberry. Strictly a Dewberry, both in habit of growth and flavor of fruit. It bears a heary crop one year after being planted, and is always prolific. It is very early, plant is hardier than a blackberry, and never fails. Fifty-four berries were gathered which filled a quart box, while it took 347 select Early Harvest Blackberries to fill the same box. It ripens soon after strawberries, and sells at higher prices.

Rathbun. Fruit is of enormous size, far surpassing that of any other variety, 45 berries filling a quart box; single specimens measure $13 / 4$ inches in length, and the whole crop is very uniform. Fruit is quite firm, sweet, luscious, with no core, and ships well. Plant is very hardy, having produced a good crop of fruit when Erie and Minnewaski in the same field failed on account of severe freezing. A strong, erect grower, with branches curving over, touching the ground and propagating themselves like a blackeap Raspberry.

PRICES OF BLACKBERRIES.

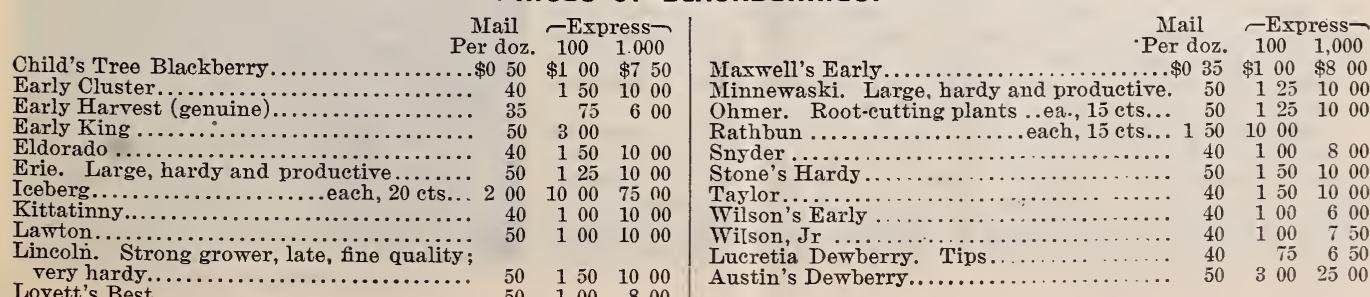




\section{THE LOGAN BERRY.}

(Raspberry-Blackberry.)

THIS TNIQUE FRUIT has now been well tested in the eastern states and proved itself a valuable acquisition to our list of small fruits. It is a seedling from the Aughinbaugh blackberry, a wild pistillate variety of California,

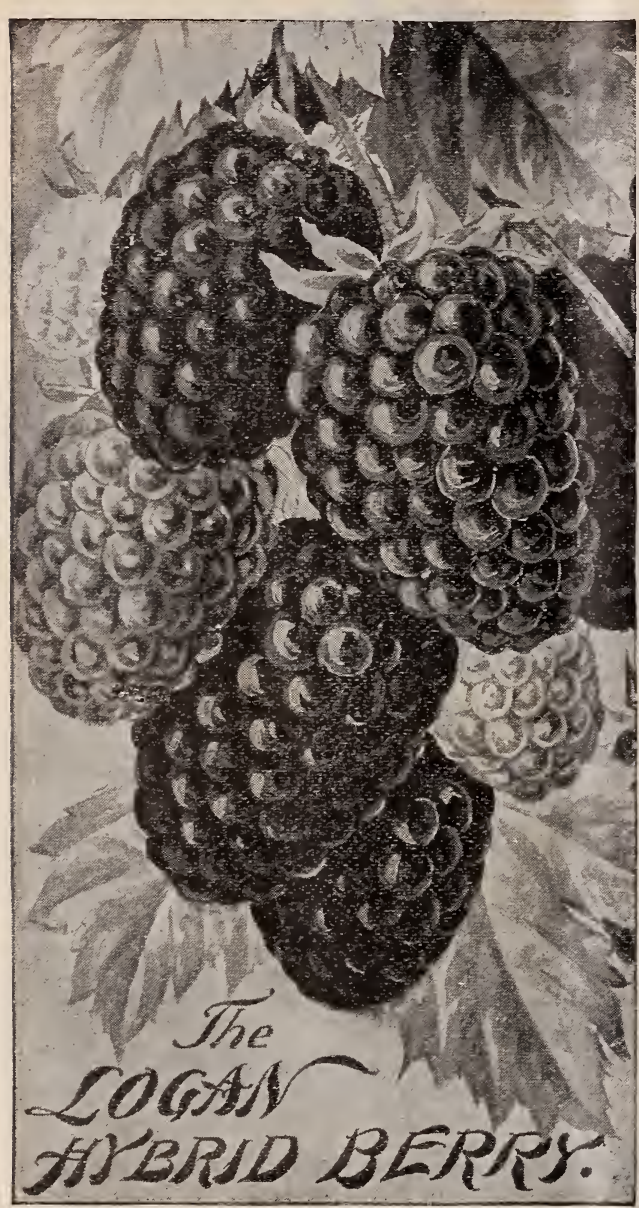

crossed or fertilized by pollen of the Red Antwerp raspberry.

The PLANTs are described as unlike either raspberry or blackberry, but of low-growing habit, more like the dewberry. It has very large, strong canes, or vines, without thorns, but with very fine soft spines, like those found on raspberry plants; leaves are deep green color, coarse and thick, more like those of the raspberry than the blackberry.

THE FRUIT is as large as the largest blackberry, of same shape, with globules as in that fruit; color, when fully ripe, a dark, rich red. It partakes of the flavors of both the raspberry and the blackberry, being a combination of the two mixed-a very pleasant, mild, vinous flavor, delightful to the taste, not found in any other fruit. It is excellent for the table, eaten fresh or cooked, and for jelly or jams is without an equal. The fruit is firm and carries well, and the seeds are small and few.

THE VINES are enormous bearers, ripening fruit very early. The crop begins with strawberries, and is nearly all ripe and gone before raspberries become plentiful, rendering it a very valuable fruit for market. Genuine stock is very limited. Beware of seedlings offered by some. Price, by mail, postpaid, $10 \mathrm{cts}$. each, $50 \mathrm{cts}$. per doz., $\$ 5$ per 100 , $\$ 35$ per 1,000 .

\section{MIGH BUSH CRANBERRY.}

A very ornamental fruit-bearing shrub of the Snowball family. Grows 4 to 6 feet high and produces in abundance berries in bunches like the mountain ash, but about the size of cranberries, which hang on long after the leaves are gone and give the tree a very attractive appearance in early winter. They are excellent for sauce-or jelly, of an aromatic pleasant, though entirely different from any other known fruit. Price, mail or express, 10 cts. each, $\$ 1$ per doz., $\$ 7.50$ per 100 .

\section{CHILD'S (BURBANK'S) MAYBERRY.}

An improved variety of the Mayberry, the result of a cross with the Cuthbert raspberry. It grows in sturdy tree form 6 to 8 feet high, ripening its fruit before strawberries and a month before the earliest raspberries. The bushes hare spreading tree-like tops, large, bellshaped, pendulous blossoms, and great golden yellow berries, sweet and luscious beyond description. Its earliness makes it the most important of all fruits. Price, mail or express, 10 cts. each, \$1 per doz., \$5 per 100.

\section{GRAPES, MARDY.}

(For prices, read page 29.)

Columbian is claimed to be the largest Grape ever placed on the market, and forms large, compact clusters. It is an excellent table Grape, and excels all others for jelly. Vine is a strong grower, free from mildew, enormously productive of handsome clusters of immense Grapes, black in color, ripening midseason.

Eaton. A healthy, vigorous vine, free from mildew; character of Moore's Early and Pocklington. Bunch, very large, compact, often double-shouldered; bcrries very large, many an inch in diameter, round, black, covered with a heavy blue bloom; adheres firmly to the stem; skin thin but tough, with no bad taste; pulp large and tender, separating freely from the seeds. Quality equal to or better than Concord. Very valuable.

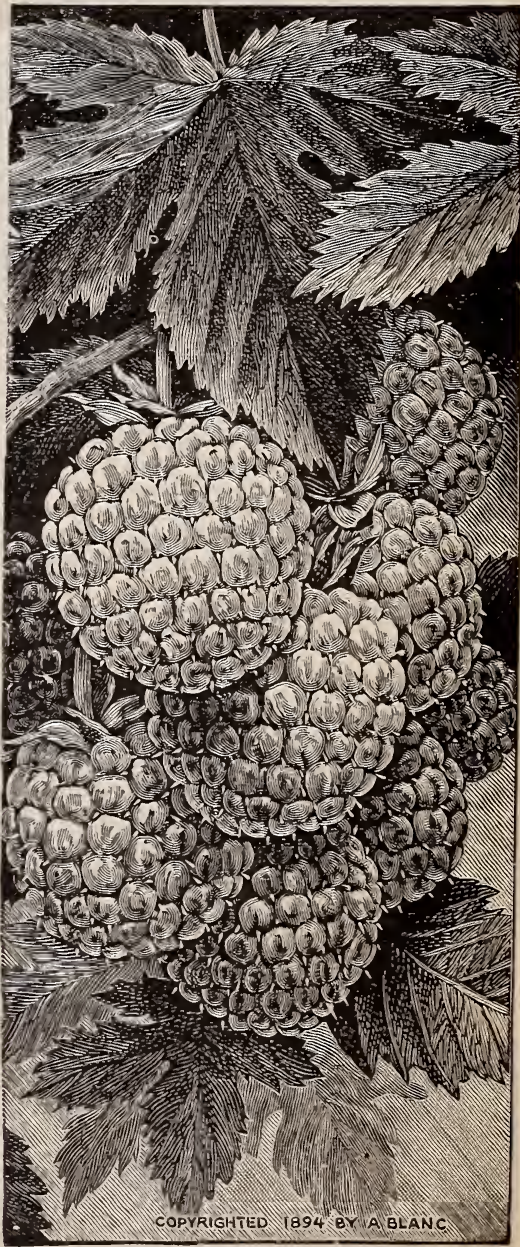

Child's (Burbank's) Mayberry. 
GRAPES, continued.

Green Mountain. Claimed to be the earliest, hardiest and best-flarored early Grape yet introduced. Vine is a rery strong, healthy grower and very productive. Clusters of medium size, often shouldered; berries larger than Delaware, with skin thin and quality fine; pulp tender, sweet and free from foxiness.

Early Onio. Claimed by the introducers to be "the earliest black Grape known; RIPENS TEN DAYS TO TWO WEEKS BEFORE MOORE'S EARLY; bunches large, compact and shouldered; berry medium, corered with a heary bloom; fully as hardy as Concord. A rigorous grower, very productire of fruit of good quality. One of the best shippers; THE ONLY EARLY GRAPE THAT WILL XOT SHELL."

Moore's Early. Bunch large, berry large, round, with heary blue bloom. Vine exceedingly hardy. Its earliness makes it desirable for an early market.

Niagara. Vine hardy, an unusually strong grower; bunches very large and compact, sometimes shouldered; berries large, mostly round, light greenish white, semi-transparent, slightly ambered in the sun; skin thin but tough, and does not crack; has very little pulp, is melting and sweet to the center.

Worden. A beautiful large, black Grape, larger, earlier and decidedly better than Concord. Vine more productive, healthier and hardier.

CAMPBELL'S EARLY. This is not a chance seedling, but the result of carefully conducted experiments by the originator through successive crossing of the most promising varieties which he had produced or tested within the past 30 years.

SoMe poINTs of SPECIAL Merit in CAMPBELL'S EARLY are a rery strong, vigorous, hardy vine, with thick, healthy mildew-resisting foliage, and abundant clusters of rery large, compact and handsome Grapes. Berries large, often an inch or more in diameter; black, with light purple bloom; skin thin but very tenacious; flesh firm but tender, parting easily from its few and small seeds. Flavor rich, sweet, slightly vinous, free from foxiness; as the seeds part readily, they need never be swallowed. Season very early, from middle to last of August at Delaware, Ohio, and its keeping qualities are remarkable, clusters having hung upon the vines sound and perfect for six weeks or more after ripening, with no tendency to fall off or shell from the stem.

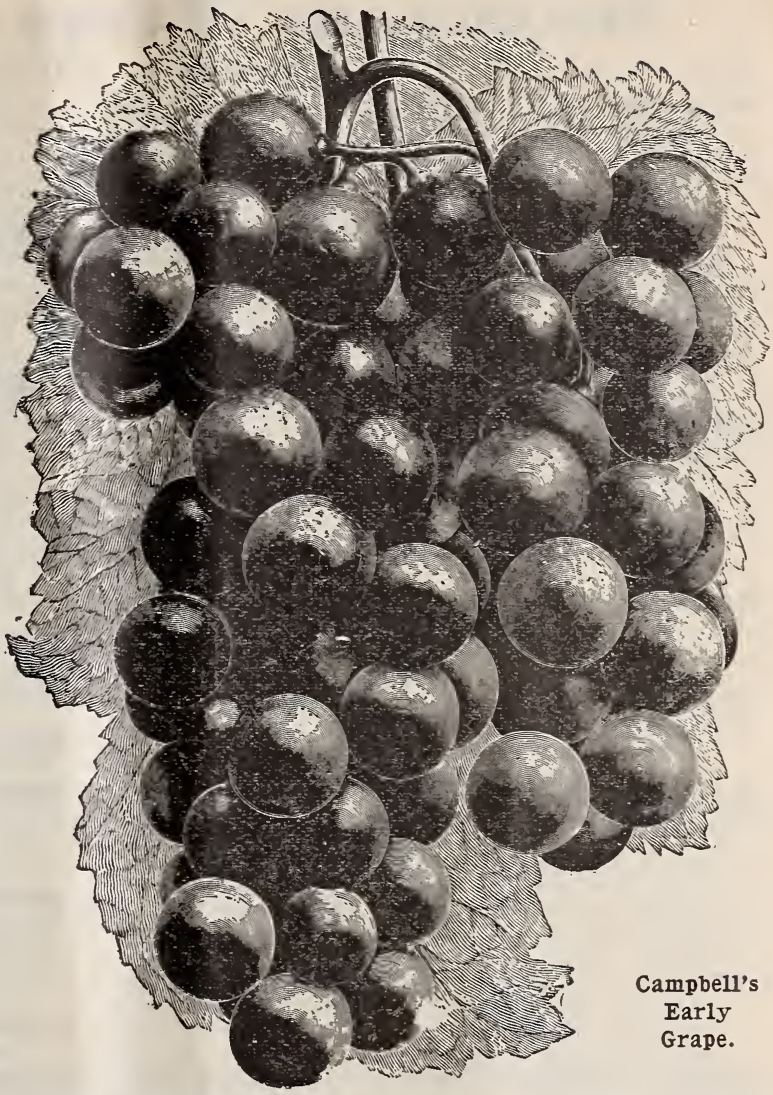

PRICES OF GRAPES.

\begin{tabular}{|c|c|c|c|c|c|c|c|c|}
\hline & - Ma & 1-year & $\begin{array}{l}\text { vines } \\
\text { ExI }\end{array}$ & ress $\longrightarrow$ & $-\mathrm{MI}$ & 2-year & $\begin{array}{l}\text { vines } \\
\text {--Expy }\end{array}$ & ess- \\
\hline & Each $\mathrm{P}$ & er doz. & 100 & 1,000 & Each 1 & Per doz. & 100 & 1,000 \\
\hline ighton. Midseason, re & $\$ 007$ & $\$ 050$ & $\$ 500$ & $\$ 1000$ & $\$ 010$ & $\$ 075$ & & \\
\hline 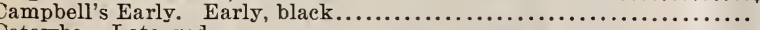 & 100 & 1000 & & & 150 & 1500 & & \\
\hline 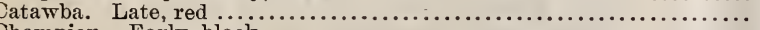 & 07 & 50 & 300 & 2500 & 10 & 75 & 400 & \\
\hline ............ & 07 & 50 & 200 & 1500 & 10 & 75 & 300 & 2000 \\
\hline …....... & 25 & 200 & & & 40 & 350 & & \\
\hline$\cdots \ldots \ldots \ldots$ & 07 & 50 & 200 & 1500 & 10 & 75 & 300 & \\
\hline 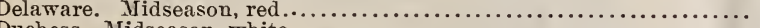 & 07 & 50 & 400 & 3500 & 10 & 75 & 500 & 4000 \\
\hline 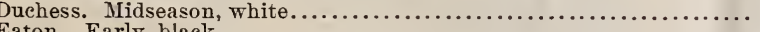 & 10 & 50 & 600 & 5000 & 15 & 100 & & 7500 \\
\hline ....................... & 10 & 50 & 500 & & 5 & 150 & 750 & \\
\hline .......... & 10 & 50 & 300 & 2500 & 5 & 75 & 400 & 3500 \\
\hline$\ldots \ldots \ldots \ldots$ & 10 & 50 & 400 & 3000 & 5 & 100 & 500 & 5000 \\
\hline aite.......... & 20 & 300 & 2500 & & 25 & 300 & 3000 & \\
\hline .... & 07 & 50 & 300 & 2000 & 10 & 75 & 500 & 4000 \\
\hline ..... & 07 & 50 & 200 & 1500 & 10 & 75 & 250 & 2000 \\
\hline on. & 15 & 100 & 750 & 5000 & 5 & 100 & 1200 & 10000 \\
\hline Ear?y, & 10 & 75 & 500 & $20 \quad 00$ & 15 & 100 & 600 & 4000 \\
\hline Late, white.... & 10 & 100 & 1000 & 7500 & 5 & & 1000 & 7500 \\
\hline ....... & 10 & 150 & 1000 & & 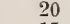 & & & \\
\hline$\because \ldots$ & 10 & 10 & 30 & 2500 & 15 & 125 & 350 & 3000 \\
\hline 1, white. & 10 & 100 & 500 & 2500 & 15 & 100 & 500 & 4000 \\
\hline k........ & 07 & 50 & 25 & 2 & 10 & 100 & 400 & 3000 \\
\hline . & 07 & 50 & 15 & 1200 & 10 & 75 & 200 & 2000 \\
\hline rly & 15 & 150 & 1000 & & 25 & 300 & 2000 & \\
\hline te..... & 07 & 60 & 300 & 1500 & 10 & 75 & 250 & 2000 \\
\hline (5) & 07 & 50 & 40 & 3000 & 10 & 75 & 500 & 4500 \\
\hline Mids & 10 & 150 & 1000 & & 15 & 100 & 1500 & \\
\hline aes. & 15 & 100 & 500 & 4500 & 25 & 150 & 750 & \\
\hline 姜. & 20 & 125 & 80 & & 5 & 200 & 1200 & \\
\hline 至 & 07 & 50 & 30 & 2000 & 10 & 100 & 400 & 3000 \\
\hline ng. E & 07 & 30 & 300 & 2500 & 10 & 100 & 500 & \\
\hline er. MI & 10 & 100 & 300 & 2500 & 15 & 150 & 650 & 6000 \\
\hline
\end{tabular}

Three-year vines of above varieties, bearing age, at an advance of 25 per cent above the price of two-year vines. 


\section{Deciduous Trees and Shrubs.}

Packing 50 cts. to $\$$ I per bale extra.

AHLANTUS, "Tree of Heaven." A very handsome ornamental tree, introduced into this country from China many years ago, yet unknown in many localities. It is a very rapid grower, perfectly hardy, succeeds in all soils, and grows 6 to 10 feet high, with very stout stem, the first summer. Its magnificent leaves, 5 to 6 feet long, give quite a tropical appearance. In China it is known as the "Tree of Heaven," a name suggested by its majestic form and great beauty. The trees grow to a good height and bear in great profusion large panicles of bloom. PrICE, 1-year trees, 4 to 6 feet, 50 cts. each, \$5 per doz. ; 1-jear trees, 2 to 4 feet, 25 cts., $\$ 2.50$ per doz.

BEECH, Purple. Native of Germany. An elegant, vigorous tree, growing to 40 or 50 feet high, or can be shorn and kept in a compact ball. Foliage in spring is deep purple, changing later in season to crimson. Very conspicuous. PRICE, by mail or express, 1 to 2 feet, 15 cts.; by express, 2 to 3 feet, 25 cts.; 3 to 5 feet, $35 \mathrm{c}$. each; 5 to 6 feet, $50 \mathrm{c}$. each.

BIRCH, Cut-leaved Weeping. Tall, slender, with graceful drooping branches, silvery white bark and delicately cut foliage. Conspicuous and desirable. PrICE, 50 cts. each, $\$ 5$ per doz.

White. A handsome tree, with white bark; very striking in winter. The trunks look like marble columns rising out of the snow. PrICE, 8 to 10 feet, $35 \mathrm{cts}$. each, $\$ 20$ per 100 .

CATALPA Speciosa. These are rapid-growing trees of tropical appearance, flowering in July, Their blossoms are large, very showy and quite fragrant; leaves very large, heart-shaped, yellowish green. A magnificent variety; very hardy; blooming in large clusters while still very young; very desirable. PRICE, mail or express, 35 cts.

Bungei. One of the most attractive trees. It forms a perfect half globular or umbrella head, with foliage of a deep green color, laid with great precision, making a beautiful roof of leaves. A most striking and ornamental tree upon the lawn. PRICE, express, 6 to 8 feet, top-grafted, $\$ 1$ each, $\$ 10$ per doz.

CORNUS or DOCWOOD, White-flowering (Cornus florida). Mr. F. J. Scott, in his "Suburban Home Grounds," says of the Dogwood: "It is remarkable for the size and showiness of its white blossoms, which make their appearance in April, before the leaves, and cover the tree like immense snowflakes. They are 2 to 3 inches in diameter. Those who have been familiar with it only in the woods can form but a poor idea of its beauty when grown in rich soil and open exposure. In such places it is not only superb in its April crown of white blossoms and its mass of summer leares, but in autumn its foliage, turning to a deep red, makes the tree a brilliant companion to the varied-hued maples, the golden sassafras, the scarlet oak and the glowing bronze of the liquidambar. The fruit is scarlet." Mr. Scott adds that trees should be obtained from a nursery, as those taken from the woods rarely grow well, or become well formed trees. PRICE, by mail, $11 / 2$ to 2 feet, 25 cts.; by express, 3 to 4 feet, 25 cts.

Red-flowering $(C . f$. rubra). This a great improvement upon the otherwise unrivalled white-flowering variety. It possesses the same freedom of flowering, producing what might be termed a drift of bloom of a bright, fresh and cheerful rosy red. In habit it is more upright; the foliage larger, somewhat more velvety, darker green in summer, and even richer and more crimson. The fruit or berries are the same as those of the species.

PARSONS SAYS OF IT: "Flowers suffused with bright-red color, lasting long; a fresh, pronounced red, continuing with the flowers from the beginning to the end of its bloom. Planted with the white variety the effect is unrivalled."

MEEHAN SAYS OF IT: "Of the most beautiful rosy pink color, bordering on red. A growing plant before me also shows the leaves to have a rich, velvety appearance, and to be darker than those of the white variety. * * * * That this is undoubtedly a grand acquisition to the list of ornamental flowering trees, no one will doubt after seeing it in bloom." PricE, by express, 2 to 3 feet, 50 cts., 3 to 4 feet, $\$ 1$.

Weeping $(C$. $f$. pendula). A weeping form of the white-flowering rariety, unlike that of any other weeping tree. It possesses the properties of the species in early and profuse bloom, brilliant autumn foliage and attractive fruit in winter. PrICE, by express, $2 \frac{1}{2}$ to 3 feet, 50 cts.

GINKGO biloba (Salisburia adiantifolia). This is one of the most beautiful and peculiar of all hardy exotic trees. The fruit is about the size of a large cherrs, and greenish yellow when ripe. Like the cherry, it has fleshy pulp with a single stone or seed; is highly esteemed for its astringent properties and its reputation for promoting digestion. Tree is perfectly hardy, attains a height of about 80 feet, and has a straight trunk with a pyramidal head. Price, 2 to 3 feet, 25c. each, 3 to 4 feet, 35c. each.

ELM, American. A noble spreading and drooping tree; rapid grower. PRICE, 6 to 8 feet, 25 cts, each, $\$ 2.50$ per doz., $\$ 15$ per $100 ; 8$ to 10 feet, 35 cts. each, $\$ 3.50$ per doz., $\$ 25$ per 100 .

HORSE CHEST NUT. PrICE, 6 to 8 feet, $60 \mathrm{cts}$. each, $\$ 6$ per doz., \$40 per 100 .

JAPAN FLOWERING CHERRY. A very attractive plant in early spring, when covered with large double rose-colored blossoms. PRICE, 3 to 4 feet, 25 cts. each, or 3, all different, for 50 cts.

LINDEN, American. A rapid-growing, large, handsome tree, with very large leaves. PRICE, 6 to 8 feet, 20 cts. each, $\$ 2$ per doz., $\$ 10$ per $100 ; 8$ to 10 feet, 25 cts. each, $\$ 2.50$ per doz., $\$ 15$ per $100 ; 10$ to 12 feet, 50 cts. each, $\$ 5$ per doz., $\$ 30$ per 100 .

LOCUST. A moderately rapid-growing tree; blossoms very handsome and fragrant; wood very durable and raluable. Price, 6 feet, 15 cts. each, $\$ 1.50$ per doz.; 8 to 10 feet, 25 cts. each, $\$ 2.50$ per doz.

MAPLE (JAPAN), Acer polymorphum. The famous Japanese Dwarf Maple. None of autumnal trees excel these. Some change their colors of leaves to yellow, others to red in autumn. Some of the varieties give their rich crimson coloring in the spring, when they shoot, as well as in autumn before they fall.

No. 1. Beni Seigen. Blood-red. 2 feet, 50 cts., each, $\$ 5$ per doz.

No. 2. Sanguineum. Blood red; very striking. 2 feet, 50 cts. each, \$5 per doz.

No. 3. Osaka-dsuki. Deep red inlautumn. 2 feet, 50 cts, each, $\$ 5$ per doz.

No. 4. Dissectum rubrum. Deep maroon; richly fringed thread-like leaflet. $50 \mathrm{cts}$. each, $\$ 5$ per doz.

No. 5. Atropupureum. Deep maroon. 2 feet, $50 \mathrm{cts}$. each, $\$ 5$ per doz.

No. 6. Roseum. Deep maroon, small narrow leaves. 2 feet, 50 cts. each, $\$ 5$ per doz.

No. 7. Scolopendifolium. Dark red; fine narrow leaves. 2 feet, 50 cts. each.

No. 10. Aureum. Golden foliage. 2 feet, 50 cts. each, $\$ 5$ per doz.

No. 12. Dissectum variegatum. Thread-like fringed foliage. 2 feet, 50 cts. each, $\$ 5$ per doz.

No. 22. Versicolor. Crimson, white and green. 2 feet, 50 cts. each, $\$ 5$ per doz.

No. 23. Atropurpureum variegatum. Bright crimson and deep maroon. 2 feet, $50 \mathrm{c}$. each, $\$ 5$ per doz.

No. 30. Dantsugi Momiji. Five to 7 kinds grafted on single stem. 2 feet, $\$ 1$ each, $\$ 10$ per doz.

No. 31. Megane. Five to 7 kinds grafted on two stems and twisted in shape of figure " 8 ". \$1 each, $\$ 10$ per doz.

One plant each of 13 above varieties, your selection, for $\$ 5$. In ordering, please designate them by their catalogue number. 
MAPLE, Norway. A large, handsome tree of spreading, rounded form, with broad, deep green, shining leaves; very compact; of stout and vigorous growth; very ornamental. PRICE, 6 to 8 feet, $30 \mathrm{cts}$. each, $\$ 3$ per doz., $\$ 15$ per $100 ; 8$ to 10 feet, 40 ets. $\$ 4$ per doz., $\$ 20$ per $100 ; 10$ to 12 feet, 60 cts. each, $\$ 6$ per doz., $\$ 35$ per 100.

Sugar or Rock. Of elegant, pyramidal form and stately growth, with beautiful foliage, turning to brilliant colors in the fall; desirable for lawn or street. PRICE, 6 to 8 feet, 25 cts. each, $\$ 2.50$ per doz., $\$ 12.50$ per $100 ; 8$ to 10 feet, 30 cts. each, $\$ 3$ per doz., $\$ 20$ per $100 ; 10$ to 12 feet, 50 cts. each, $\$$ per doz., $\$ 30$ per $100 ; 12$ to 14 feet, 60 cts. each, $\$ 6$ per doz., $\$ 40$ per 100 .

Ash-leaved. A rapid-growing, round-headed tree, with handsome, smooth green bark. PRICE, 6 to 8 feet, 20 cts. each, $\$ 1.50$ per doz., $\$ 10$ per $100 ; 8$ to 10 feet, 25 cts. each, $\$ 2$ per doz., $\$ 15$ per $100 ; 10$ to 12 feet, 30 cts. each, $\$ 2.50$ per doz., $\$ 20$ per 100 .

Silver. Of rapid growth; easily transplanted; attains large size and gives immediate shade; popular for street planting. PRICE, 6 to 8 feet, 15 cts. each $\$ 1.50$ per doz., $\$ 7.50$ per $100 ; 8$ to 10 feet, 20 ets. each, $\$ 2$ per doz., $\$ 12.50$ per $100 ; 10$ to 12 feet, 25 cts each, $\$ 2.50$ per doz., $\$ 15$ per 100

Cut-leaved. Leaves beautifully cleft; forms a handsome tree. PRICE, 8 to 10 feet, 25 cts. each, $\$ 2.50$ per doz., $\$ 15$ per $100 ; 10$ to 12 feet, 35 cts. each, $\$ 3.50$ per doz., $\$ 20$ per 100 .

Sycamore. A handsome tree of rapid, upright growth; large leaves, resembling the Norway Maple when young. PrICE, 6 to 8 feet, 25 cts. each, $\$ 2.50$ per doz., $\$ 15$ per $100 ; 8$ to 10 feet, 40 cts. each, $\$ 1$ per doz., $\$ 20$ per $100 ; 10$ to 12 feet, 60 cts. each, $\$ 6$ per doz., $\$ 30$ per 100 .

ORIENTAL PLANE. A very rapid-growing tree of large, spreading form; foliage large, handsome and free from insects. PRICE, 6 to 8 feet, 25 cts. each, $\$ 2$ per doz., $\$ 15$ per $100 ; 8$ to 10 feet, $35 \mathrm{cts}$. each, $\$ 3.50$ per doz., $\$ 20$ per 100 .
PAULOWNIA Imperialis. A magnificent tropicallooking tree from Japan; of extremely rapid growth, with leares 12 to 14 inches in diameter. Blossoms trumpet-shaped, formed in large upright panicles in May, producing a beautiful effect. PrICE, 4 to 6 feet, 35 cts.; 5 to 7 feet, $50 \mathrm{cts}$.

POPLAR, Bolleana. A very compact, upright grower, resembling the Lombardy; leares glossy green abore and silvery beneath. PRICE, 8 to 10 feet, 20 cts. each, $\$ 2$ per doz., $\$ 15$ per $100 ; 5$ to 8 feet, 15 ets. each, 1.50 per doz., $\$ 10$ per 100 .

Carolina. Very rapid grower of pyramidal form, with large, handsome, glossy leares. Popular for street planting or for immediate effect. PRICE, 8 to 10 feet, $15 \mathrm{cts}$. each, $\$ 1.50$ per doz., $\$ 10$ per 100 ; 10 to 12 feet, $20 \mathrm{cts}$. each, $\$ 2$ per dóz., $\$ 15$ per 100 12 to 15 feet, 25 cts. each, $\$ 2.50$ per doz., $\$ 20$ per 100 .

Lombardy. Rapid, upright, symmetrical grower always of striking effect. PRICE, 12 to 15 feet, 30 cts. each, $\$ 20$ per $100 ; 15$ to 20 feet, 40 cts. each, $\$ 25$ per $100 ; 20$ to 30 feet, 50 cts. each, $\$ 30$ per 100 .

Tulip. A magnificent tree, of tall, pyramidal habit, with broad, glossy leaves; free from insects; has beautiful tulip-like flowers. PRICE, 6 to 8 feet, 35 cts. each, $\$ 3.50$ per doz., $\$ 20$ per $100 ; 8$ to 10 feet, 50 cts. each, $\$ 5$ per doz., $\$ 40$ per 100 .

Van Geert's Golden. Fine golden yellow foliage, retaining its brilliancy throughout the season; very conspicuous and attractire. PRICE, 6 to 8 feet, 10 cts. each, $\$ 1^{\circ}$ per doz., $\$ 7.50$ per $100 ; 8$ to 10 feet, 15 ets. each, $\$ 1.50$ per doz., $\$ 10$ per $100 ; 10$ to 12 feet, $25 \mathrm{cts}$. each, $\$ 2.50$ per đoz, $\$ 15$ per 100 .

WILLOW, Babylonian or Weeping. A native of Asia,-our common and well-known Weeping Willow. Price, 8 to 10 feet, 25 cts. each, $\$ 2.50$ per doz., \$15 per 100 .

Kilmarnock Weeping. An exceedingly graceful tree, with glossy foliage and perfect umbrella head. PrICE, 50 cts. each, $\$ 5$ per doz.

Golden. A handsome tree at all seasons, but, on account of its yellow bark, particularly conspicuous in winter. PRICE, $25 \mathrm{cts}$. each. $\$ 2.50$ per doz.

\section{MARDY ORNAMENTAL FLOWERING SHRUBS.}

\section{Prices, by mail or express, 15 cts.; extra size, express, 20 cts}

ALTHEA, or Rose of Sharon. Very desirable, because they bloom in August and September, when but few other trees or shrubs are in bloom.

BERBERRY, Púrple. A beautiful shrub, with violetpurple foliage and clusters of fine red berries.

CALIFORNIA PRIVET. A rapid, upright-growing plant; foliage oval, deep green, glossy and very dense; almost an evergreen; forms a magnificent hedge. Covered in July with panicles of small, white, fragrant flowers.

CALYANTHUS. Sweet Scented Shrub. Flowers of rare chocolate color, having a peculiar, pleasant odor. Blossoms in June and at intervals afterward.

DEUTZIA gracilis. A handsome dwarf shrub from Japan. Flowers pure white, appearing rery early.

FORSYTHIA, Golden Bell. Bloom is drooping, yellow, and appears very early in spring, before the leares.

HYDRANGEA paniculata grandiflora. A fine shrub, growing 8 to 10 feet high. Flowers white, changing to pink, in great pyramidal panicles a foot long, and produced in great abundance in August or September. Hardy and valuable.

JAPAN JUDAS. A charming dwarf tree that flowers early in the spring, before the heart-shaped leaves appear, literally covering the tree with small clusters of bright rosy purple bloom.

JESSAMINE. A green, trailing shrub, producing a profusion of bright yellow bloom, extremely early in spring.

LILAC, Prince Camille de Rohan. Very distinct, reddish flowers; panicles large and very abundant; blooms early in May.

LILAC, Persian. Small foliage; bright purple flowers.

White. Very large, pure white trusses.

MIST, Purple, or Smoke Tree. Much admired for its curious fringe or hair-like flowers, that cover the whole plant, giving the appearance of dense foliage.

RED SNOWBERRY. A shrub of very pretty habit. Foliage, flowers and fruit small; fruit purplish red; hangs in clusters all winter, making the bush very attractire.

ROSA RUGOSA. It has abundant glossy foliage of great beauty, is perfectly hardy, and grows from 4 to 5 feet high. The flowers, which are produced freely all summer, are single, rich, crimson, and succeeded by clusters of large scarlet fruits.

SNOWBALL. A large shrub with great white balls of blooms in June.

SPIRAEA Billardii, Strong, upright grower, with long terminal spikes of rose-colored flowers, which it retains all summer.

Bridal Wreath (S. prunifolia). A strong-growing, handsome shrub, with pure white double flowers in May and June.

Reevesii. Flowers white, very double, in large, round clusters in great profusion over the entire bush.

Van Houttei. An upright-growing shrub, with pure white flowers in great clusters, forming cylindrical plumes nearly 2 feet long.

WEIGELIA Rosea. Fine rose-colored flowers; of erect, compact growth; blossoms in June.

WHITE FRINGE. A small natire tree of roundish form, with large leares and drooping racemes of pure white flowers, having narrow, fringe-like petals; blossoms in May or June 


\section{EVERGREEN TREES.}

We describe a few of the most attractive, hardy and desirable. Price, except where noted, 2 to 3 feet, 25 ets. each, $\$ 2.50$ per doz., $\$ 20$ per $100 ; 1$ to 2 feet, 20 cts. each, $\$ 2$ per doz., $\$ 10$ per $100 ; 3$ to 4 feet, 50 ets. each, $\$ 5$ per doz., \$35 per 100. Special prices for larger sizes.

ARBORVITAE, American. Valuable for screens and hedges. PRICE, 4 to 5 feet, shorn, 50 cts. to $\$ 1$ each; 2 to 3 feet, 25 cts. each, $\$ 2.50$ per doz.; 1 to feet, $\$ 7.50$ per 100 .

Compacta. (Parson's.) Dwarf, compact habit, deep green; symmetrical without the use of shears. Hoveyi. Dwarf, globular; has fine foliage.

Pyramidal. Upright, compact; like the Irish Juniper.

Chinese Golden. Small, elegant, nearly spherical, with bright yellow-tinged foliage.

Elegantissima. Of upright, pyramidal form; young foliage prettily tipped with golden yellow, becoming bronze in winter.

George Peabody. Dwarf, compact; foliage bright golden yellow throughout the summer. The best golden variety.

Can also furnish Siberian, Globosa, Maxwell, Tataricum, Aaroniana and Vervæneana at same prices.

BOX, Tree. Dwarf, leaves small, deep green. Valuable for decorations. PRICE, sborn, 1 to 2 feet, 50 cts.; 2 to 3 feet, $\$ 1 ; 3$ to 4 feet, $\$ 2$.

Dwarf. Used for edging; single specimens are desirable for small grounds. PRICE, 6 to 12 inches, 2 ets.; 12 to 18 inches, 50 cts.

JUNIPER, Irish. Of erect, dense, conical outline, resembling a pillar of green. PRICE, 2 to 3 feet, 15 cts.; 3 to 4 feet, 25 cts.; 4 to 5 feet, 35 cts.

Swedish. A small, handsome, pyramidal tree. with yellowish-green foliage; very conspicuous. PRICE, 2 to 3 feet, 25 cts.; 3 to 4 feet, 35 cts.

NORDMANN'S FIR. A majestic tree of symmetrical form, vigorous and very hardy. Its foliage is massive, dark green; strikingly handsome. PRICE, 1 foot, 50 cts.; 2 to 3 feet, $\$ 1 ; 3$ to 4 feet, $\$ 2$.

PINE, White. A noble tree, upright, of spreading habit; foliage long, light green. Desirable for roadways or large lawns. PRICE, 2 to 3 feet, 25 cts.; 4 to 6 feet, 50 cts.

RETINOSPORA, Japan Cypress. Beautiful; needs protection north of New York.

Plumosa. Dwarf, with dense, slender, feathery branches.

Plumosa aurea. Similar to above, but with goldentipped foliage.

Pisifera. Strong-growing; light green; makes handsome hedges.

Filifera. Fine, wiry foliage; very odd.

Glauca. Dwarf, compact, conspicuous.

SPRUCE, Norway. Extremely hardy, of lofty, rapid growth and pyramidal form; branches assume a graceful, drooping habit with age. Popular for single specimens, for shelter, windbreaks or hedging. PRICE, 2 to 3 feet, 25 cts.; 3 to 5 feet, 50 cts.

Douglas. Large, conical, with smooth bark and light green foliage; handsome. PrIcE, 1 to 2 feet, 50 cts.

Colorado Blue. The popular blue Evergreen; of pronounced bluish tint; very attractive. PRICE, $1 \frac{1}{2}$ to 2 feet, 50 ets.

Black Hills. Of short growth; very dense and compact, with dark foliage. PRICE, $1 \frac{1}{2}$ to 2 feet, 50 cts.

Oriental. Of medium size; very dense habit. PRICE, 50 cts.

Hemlock. Remarkably graceful and beautiful, with beautiful branches, and delicate dark foliage. Makes a handsome hedge. PrICE, 2 to 3 feet, 50 cts.; 3 to 4 feet, 75 cts.

YEW, English. A large bush or tree, 30 to 40 feet when fully grown. Is deusely branched and can be shorn into a variety of shapes and forms. PRICE, shorn, 3 to 6 feet, $\$ 1$ to $\$ 5$ each; PRICE, unshorn, 2 to 4 feet, 50 cts. to $\$ 1$.

\section{MAGNOLIAS.}

MAGNOLIA glauca. The Jersey swamp Magnolia. Flowers fragrant. 1 to 2 feet, 25 cts.; large, 50c. Conspicua. Chinese. Covered in early spring with white flowers as large as tulips. 2 to 3 feet, $50 \mathrm{cts}$. Purpurea. Purple-flowered. 2 to 3 feet, $50 \mathrm{cts}$.

Tripetala. (Umbrella.) A small tree with immense leares and large white flowers. 3 to 4 feet, $50 \mathrm{cts}$.

Soulangeana, Very hardy, with large white and purple flowers. 3 to 4 feet, 50 ets.; 2 to 3 feet, $25 \mathrm{c}$. Grandiflora. Erergreen. The magnificent erergreen Magnolia of the south; blooms in all its grandeur entirely unprotected here. PRICE, 1 to 2 feet, by mail, 35 cts.; 2 to 3 feet, by express, 50 ets.

\section{MEDTING PLANTS.}

AMERICAN ARBORVITAE. 2 to 3 feet, $\$ 10$ per 100 ; 3 to 4 feet, $\$ 15$ per $100 ; 4$ to 6 feet, $\$ 20$ per 100 .

CALIFORNIA PRIVET, 2 to 3 feet, $\$ 5$ per $100, \$ 10$ per 1,$000 ; 1$ to 2 feet, $\$ 4$ per 100 , $\$ 25$ per 1,000 .

OSAGE ORANGE. 1-year, 50 cts. per 100, $\$ 2.50$ per $1.000 ; 2$-year, 75 cts. per $100, \$ 5$ per 1,000 .

TRIFOLIATE ORANGE. 2-year, $\$ 3$ per $100, \$ 20$ per 1.000 ; 1-year, $\$ 2$ per $100, \$ 10$ per 1,000 .

\section{HARDY VINES.}

AKEBIA quinata. Shining sub-evergreen foliage and clusters of fragrant chocolate-colored flowers. PrICE, mail or express, 15 cts. each, $\$ 1.50$ per doz.

AMPELOPSis quinquefolia. (Virginia Creeper.) PRICE, mail or express, 15 cts. each, $\$ 1.50$ per doz.

Veitchii. (Japan Iry, or Boston Ivy.) Foliage forms a dense sheet of green; in fall it is a flame of crimson. Price, mail or express, 25̄c. each, $\$ 2.50$ per doz.

BIGNONIA grandiflora. (Trumpet Flower.) Blossoms immense; gorgeous crimson and yellow. Price, mail or express, 25 cts. each, $\$ 2.50$ per doz.

CLEMATIS flammula. (Virgin's Bower.) Flowers in masses, small, white, very fragrant. PRICE, mail or express, 15 cts. each, $\$ 1.50$ per doz.

Paniculata. Flowers white, sweet-scented, covering the plant with a mass of bloom. PRICE, mail or express, 25 cts. each.

EUONYMUS radicans variegata. Foliage small, myrtle-like, finely variegated with creamy white and rosy purple. Clings to any object, like ivy. PRICE, mail or express, $10 \mathrm{cts}$ each, $\$ 1$ per doz.

HARDY CHINESE MATRIMONY VINE (Lycium Chinense). PRICE, young plants, 10 cts. each, $\$ 1$ per doz., $\$ 5$ per 100 .

HONEYSUCKLE, Halleana. (Hall's Japan Evergreen Honeysuckle.) PRICE, mail or express, 15 cts.; large plants, by express, 25 cts.

Japan Golden. Foliage exquisitely netted with golden yellow. Flowers large, peach colored. PRICE, mail or express, $15 \mathrm{cts}$. each, $\$ 1.50$ per doz.

WISTARIA Sinensis. Flowers pale blue, borne in pendulous racemes in May and June. PrICE, mail or express, 15 cts. each, $\$ 1.50$ per doz.

sinensis alba. Flowers white, remaining somewhat longer. PRICE, mail or express, $50 \mathrm{cts}$.

\section{ORNAMENTAL GRASSES.}

EULALIA gracillima univittata. Foliage exceedingly graceful, narrow, delicate green, with silvery white midrib. Quite hardy. PRICE, mail or express, 15 cts. each, 4 for 50 cts.; large clumps, 50 cts.

Japonica variegata. Long, narrow leaves, bordered with white. Hardy. Plumes like Pampas Grass. PrICE, mail or express, $15 \mathrm{cts}$. each, 4 for 50 cts.; large clumps, 50 cts.

Japonica zebrina. Markings are yellow and across the leares. PRICE, mail or express, 15 ets. each, 4 for $50 \mathrm{cts}$; ; large clumps, 50 cts.

ERIANTHUS ravennæ. Nuch resembles the Pampas Grass; height 8 to 10 feet. PrICE, mail or express, $15 \mathrm{cts}$. each, 4 for $50 \mathrm{cts}$.; large clumps, 50 cts.

SACALINE (Polygonum sachalinense). Endures the severest drought and will flourish where no other forage plant will grow. PRICE, mail or express, 10 ets. each, $\$ 1$ per doz., $\$ 5$ per 100 . 

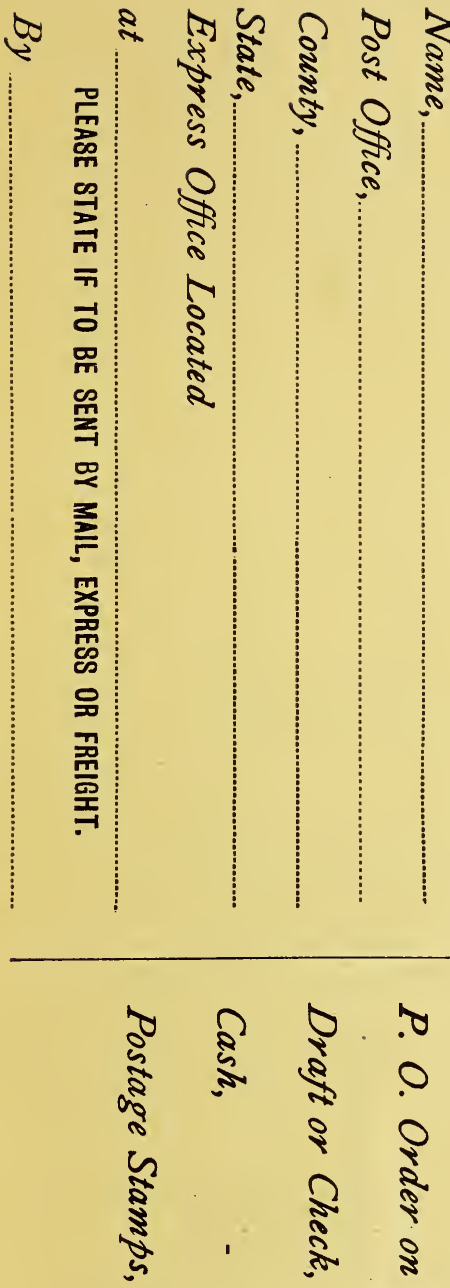

2

ta to bo to
की

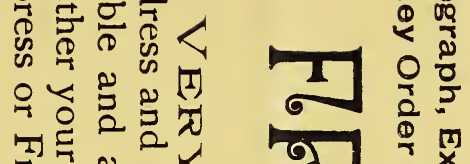
จ․, क. 0 으.

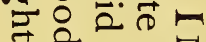
क ज ए 寻苗完 กิ б u ᄅ

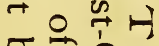
安色। उ ถ. Е ก 0 (드응

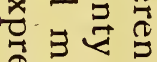
is ผैं ก थ ल एँ - 牙址 - थै थ ज.

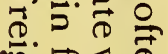

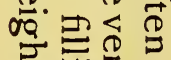
灵吉尔 ๙ ไะ ڤ

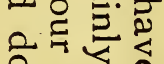
0 ○ 유유 त怘 出

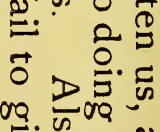
¿. 0 ᄂ ( $\sigma \varrho \gtrless$ $\overrightarrow{0} \approx$ (1) ङ

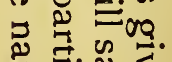

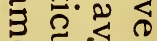
ก ह $\stackrel{2}{\circ}$ is 눙코 थ ก

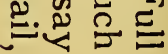

$z$

c)

4

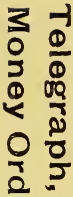

(1)

움

录

(2)

남

a

(6)

¿.

(1)

$\frac{0}{0}$

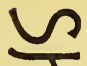

2 $\stackrel{0}{0}$

$\sigma$

c

2

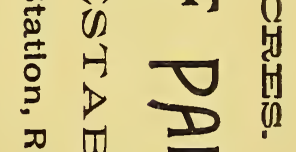

ए丁

舟

$\leftrightarrow$

[I]

[1]

$\longrightarrow 0$

(I) 0 ?

(2) $\rightarrow 0_{1}^{0}$

(5) ${ }_{0}^{0} \omega_{0}^{\infty}=\frac{2}{2}$

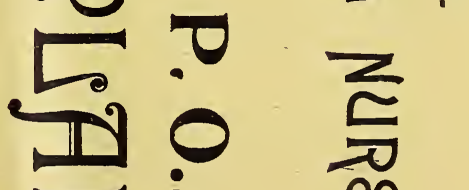

(2)

0

es

2

I]

0

I)

es 
- รว7еотม一7xอะ

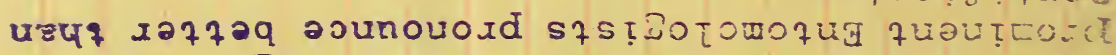

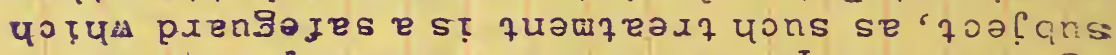

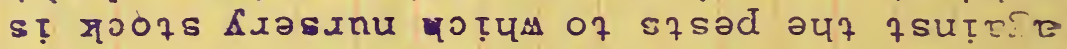
sมวषо

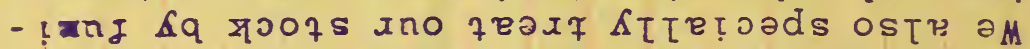

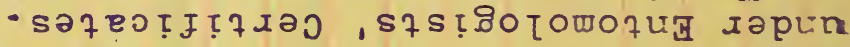

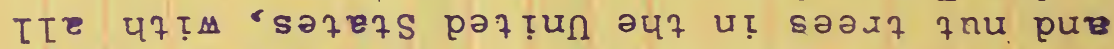

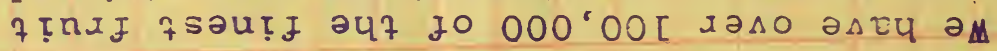




\section{PARRYS' SPECIAL COLLECTIONS.}

Special Collection No. 1.-One each of Starr, Bismarck, Flory, and Paraon luples, by mail, postpdid, for 50 cts. larger trees by express, at purchaser's expinse, \$I.

Special Collection No. 2.-Two each cf Konnce, Seneca, incoln Coreless, and Kieffer Pears, ty mail, postpaic, for 75 cts.; by express, at purchaser's expensc, $\$ 1.50$.

Special Collection No. 3.-Two each of Trimmph, Greensloro, Croshy, Lorentz, and Oldmixon Peaches, ty zail, postpaid, for 75 cts.; by express, $\$ I$.

Special Collection No. 4.-One each of Lincoln. Nyauld ing, thundauce, Satsuma, and Burbank Plums, by mail, postpaid, for.\$I; larger trees, by express, \$I.

Special Collection No. 5.-Three each of Improved Dwarf Rocky IIountain (herry, High Bush Cramberry, Logan Berry. strawbery-Raspberry, Maybery, and Japan Wintberry, Ly mail or express for $\$ I$.

Special Collection Mo. 6.-Twelve each of Brandywine, Nick ()hmer, Leader, Greenville, and Timbrell strawberries, by mail or express for \$I.

Special Collection No. 7.- Six each of Golden Queen Touton, and Gregg Raspberries: 6 each of Child's Tree, and or express for $\$ I$.

Special Collection No. 8.- One each of Colmmuns, In- dustry, Red Jacket, and (hautamqua (ionseberries: 1 each of North star. Fay s Prolific, Cherry, and thite Grape Currants, by mail cr express for $\$ I$.

Special Collection A.-Two trees each of Japan Walnuts Sieboldiana and Cordiformis, Persian Walnuts Kaghazi and Mar!eirat, and Japan Mammoth ('hestmut,-10 trees in all, 1 to ․ ft.. by mail, postpaid, for $\$ I .25$; or 2 trees of each, 2 to ft., by express, for $\$ 2$.

Special Collection B.-One tree each of Alpha, Beta, superl, Reliance, and Snccess Chestmits, grafted, 1 year old, by $t x p r \in s s$, for $\$ 5$.

Special Collection C.-Two plants each of Rocky Iountain Cherry, Trifoliate Orange, Red Jacket Gooseberry. Crunells (Gooseberry-('urrant), and Iceberg Blackberry, by mail, postpaid, for \$I.25; or larger plauts, by express, at purchaser's expense, for $\$ I .50$.

Special Collaction D.-Une strong vine each of C'olumbian, Juchess, (ireen Inuntain, Moore's Early, and Campbell's Early Grapes, ty mail or express, tcr \$I.25.

Special Collection E.-One strong vine each of Niagara, Concord, Moore's Diamond, Champion, and Campbell's Early Grapes, by mail or express, for $\$ 1$.

Special Collection F.-Four plants each of Logam Berry Iaybery, strawherry-Rasplerry and IVineberry, by mail or express, for $\$ I$.

\section{HAIR MANURE AND GROUND BONE.}

\section{The Best and Cheapest Fertilizers.}

With the farmers, fruit-growers and market-gardeners during these times of agricultural depression, the unestion of Fertillzers is a rerr important subject. Being large consumers ourselves iour fertilizer bills amounting to sereral thomsand dollars a year), we feel that onr experience nay be worth something. and do not hesitate to recommend to others Fertilizers we hare used successfully for 25 rears in competition witl most of the high-priced brands that hare been offered. About a quarter of a century ago we began to use Hair Manure. Our neighbors, noticing the wonterful results, requested us to procure some for them. This lemand las continued to grow, without any effort on our part, until now Mair Manure is rery largely used, not oul $\mathrm{y}^{\mathrm{in}}$ our immediate section, but its fame has spread throughout sereral states. In order to supply the many orders we are obliged to get it by the boat-load for this ricinity, and ship in car-lots to other sections.

Hair Manure is a by-prodnct, or refuse, from the glue factory, and is sold at a price barely corering the cost of remoring it. It is composed largely of small knuckle-bones (abont 500 pounus to the ton), hoofs, horns, hair, scraps of hide, etc.. all of which are valuable as fertilizers, and, as will be seen from the analysis, are sold at much less than their actual ralue. Hair Manure is very rich in ammonia and nitrogen, and nost excellent for all kinds of small fruits, fruit trees, rine, truck and farm crops. Ground Bone runs high in phosphoric acid, and, as will be seen in the annexed table, the commercial ralue, as giren br the I. $^{+}$. State Experiment Station for the last 10 rears, exceeds the selling price by $\$ 10$ to $\$ 17$ per ton. Hair Manure Is PACKED IN BARRELS. with weicht marked on each, just previons to shipment (9 to 12 BARRELS IER TON). OR IT IS SHIPPED IN BULK, loose, in car-lots of 12 to 20 tons. Analysis : 4 to 6 per cent ammonia, 3 to 4 per cent phosphoric acid.

Pure Bone Dust. Finely gound, dry. and suitable for drilling or sowing broadcast. Packed in barrels of about 250 pounds each. Analysis: Phosphoric acid $\left(\mathrm{P}_{2} \mathrm{C}_{3}\right) 27.76$ per cent; total nitrogen 2.10 per cent. Equivalent in bone phosphate of lime $\left(\mathrm{Ca}_{3} \mathrm{P}_{2} \mathrm{O}_{8}\right), 60.60$ per cent. Equiralent in ammonia, 2.j5 per cent.

\section{Chemical Analysis of Bone Dust and Mair Manure,}

Showing real value, selling price and the amount the real value exceeds selling price, as giren by the New Jersey State Experiment Station from rears 1880-1891.

\section{HONE DUST.}

\begin{tabular}{|c|c|c|c|c|c|c|c|}
\hline Jear. & $\begin{array}{l}\text { Station } \\
\text { Xo. }\end{array}$ & Page. & Nitreger & $\begin{array}{l}\text { Phos. } \\
\text { Acid. }\end{array}$ & $\begin{array}{l}\text { Taiue of } \\
2.0100 \text { lbs. at } \\
\text { stil. price. }\end{array}$ & $\begin{array}{l}\text { Selling } \\
\text { price of } \\
2,0 \text { co Jbs. }\end{array}$ & $\begin{array}{l}\text { Valne ex- } \\
\text { ceeds sell- } \\
\text { ing price. }\end{array}$ \\
\hline $1 \times+1$ & 43 & 30 & .74 & 31.34 & +42.25 & $\$ 2700$ & $\$ 1525$ \\
\hline 108 & 234 & 17 & 1.46 & 8100 & 38 & $2-100$ & 116 \\
\hline 1883 & 573 & 43 & 1.39 & 32.86 & $\because 986$ & 2700 & 1286 \\
\hline 1884 & 655 & 53 & 2. & 26.55 & 35) 63 & 2500 & 1063 \\
\hline $18 \times 5$ & 891 & $6:$ & 1.32 & 31.77 & 3781 & 2500 & 1281 \\
\hline $1880 ;$ & 1597 & 70 & 1.76 & 28.26 & 4036 & 2500 & - 1536 \\
\hline $188 T$ & 1762 & 73 & 1. & 29.7 & $405 \overline{7}$ & 2500 & $15 \overline{7}$ \\
\hline 180 & 2648 & 79 & 1.62 & 31.72 & 4102 & 2400 & 1762 \\
\hline 1889 & 3184 & 95 & 1.28 & 31.13 & 4126 & 2400 & $17: 6$ \\
\hline \multicolumn{8}{|c|}{ MAIR MIANURE. } \\
\hline 188 & 6077 & 32 & 5.31 & & & & \\
\hline 1887 & 1761 & 74 & 4.74 & 3.43 & $\$ 1100$ & $\$ 600$ & $\$ 500$ \\
\hline $1=91$ & & 84 & 4.98 & 4.49 & & (j) 00 & \\
\hline
\end{tabular}

Prices are F. O. B. at factorr, New York city, shipped direct to purchaser's station, purchaser paying freight References or security required from unknown parties. PRICEs NeT.

"

Hair Manure, in bulk, loose, car-lots, 10 to 20 tons Per ton. Ground Bone, in bbl..................... 2100

DESCRIPTINE CIRCCLARS OF HAIR MANURE and testimonials from parties haring used it for fruit, regetables and farm crops. mailed free on application.

\section{JOHN R. PARRY, Parry, N. J.}




\section{G I I NUTS FOR PROFIT" \\ BY JOHN R. PARRY}

With pictures carefully engraved from nature, giving correct representations of the numerous varieties of Nuts, their size, shape and general appearance, and showing habits of growth of come of them. It also devotes considerable space to the Propagation, Germination, Budding, Grafting, Cultivation, Harvesting and Marketing of Nuts. Also, a number of receipts for preparing and serving the Nuts for the table. Price, postpaid, $50 \mathrm{cts}$. Address

\section{Parrys' Pomona Nurseries, Parry, New Jersey}

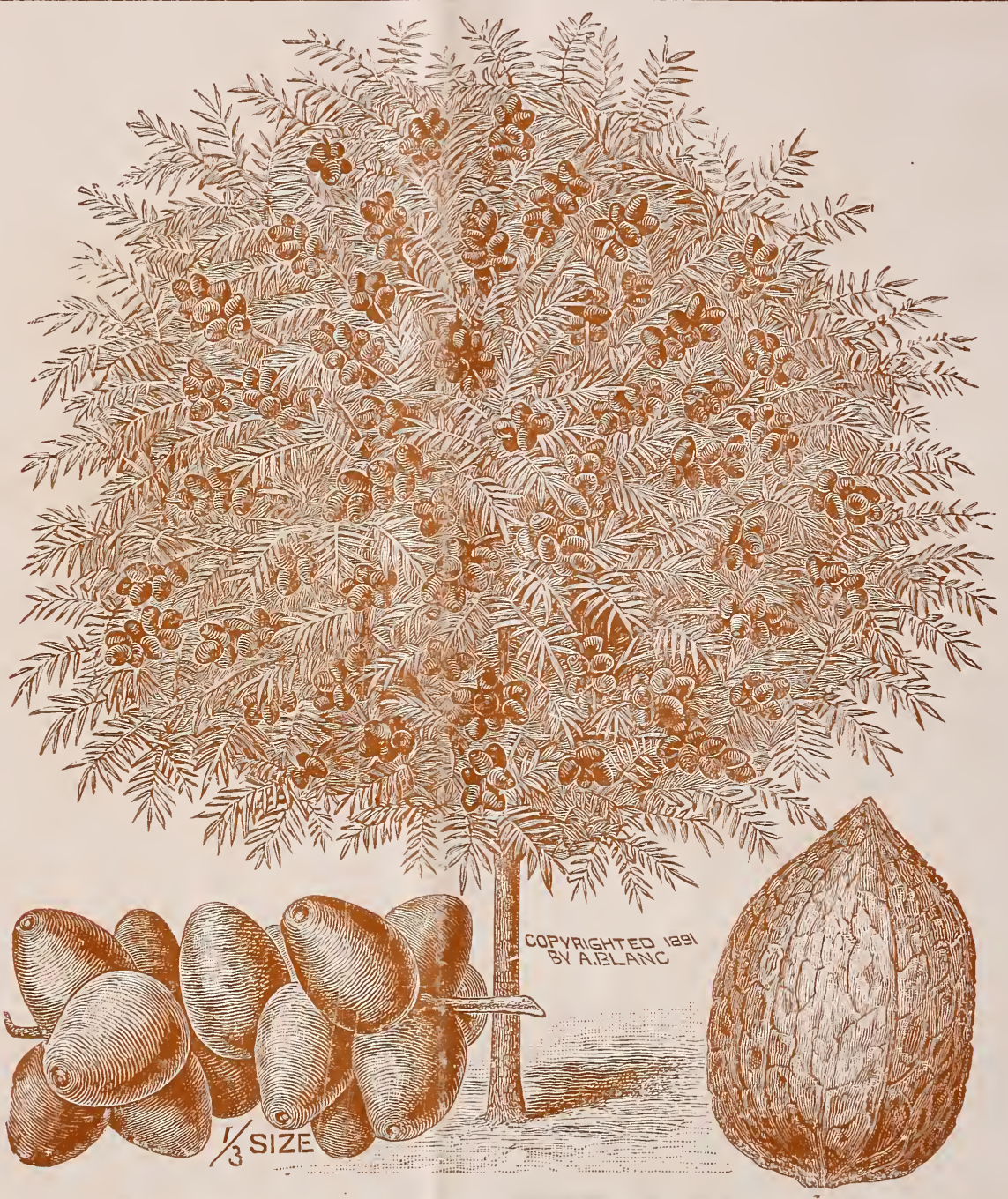

\section{JAPAN WALNUTS}

"Juglans Sieboldiana" and "Juglans Cordiformis."

The beauty of these trees, their rapidity of growth and the desirability of their Nuts, make them the most valuable ornamental Nut-producing trees ever offered to the American public. The trees are as hardy as an oak, with large, handsome leaves of a beautiful shade of green; very rapid, vigorous growers, assuming a very handsome form, and requiring no pruning. They mature early, bear young, and are immensely productive. Nuts are of high quality, borne in clusters of 15 to 20 , as shown in the above illustration.

\section{PARRYS' POMONA NURSERIES}

\section{PARRY - NEW JERSEY}

